Universidad de Lima

Escuela de Posgrado

Maestría en Derecho Empresarial

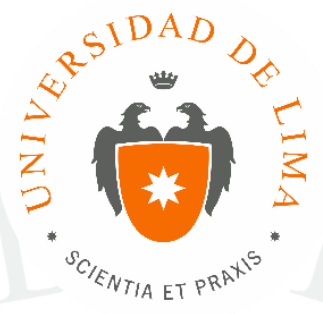

\title{
PROPUESTAS DE MEJORA DEL RÉGIMEN JURÍDICO DE TRADUCCIONES EN LOS PROCEDIMIENTOS DE CONTRATACIONES DEL ESTADO
}

Trabajo de investigación para optar el grado académico de Maestro en

Derecho Empresarial

Jorge Eduardo Praeli Pérez

Código 19964626

Asesor:

Antonio Román Calzada

Lima - Perú

Marzo, 2018 


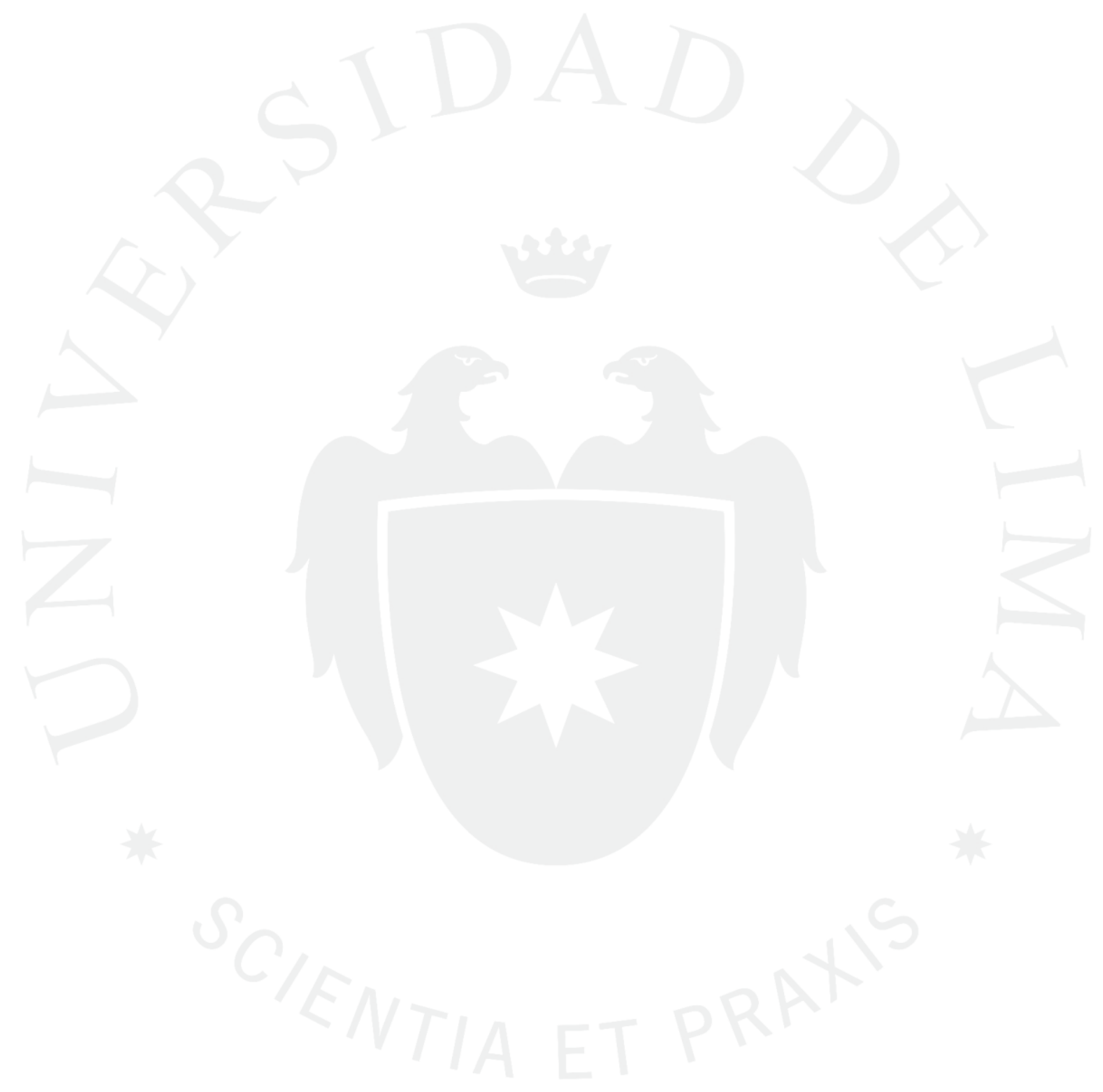




\section{PROPUESTAS DE MEJORA DEL RÉGIMEN JURÍDICO DE TRADUCCIONES EN LOS PROCEDIMIENTOS DE CONTRATACIONES \\ DEL ESTADO}




\section{TABLA DE CONTENIDOS}

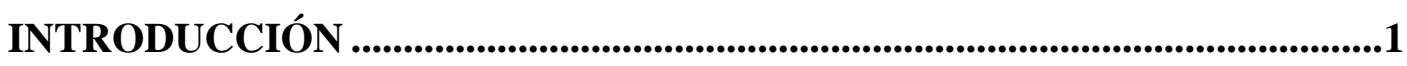

CAPÍTULO I: NOCIONES SOBRE LA TRADUCCIÓN .....................................4

1.1 Aspectos básicos de la Traducción ...................................................4

1.1.1 Definición de Traducción ..............................................................

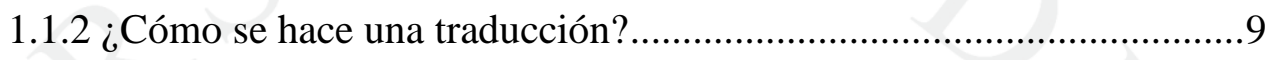

1.1.3 ¿Traducción, derecho constitucional? ...........................................10

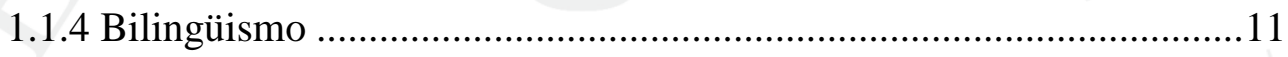

1.1.5. Requisitos del Traductor.............................................................. 14

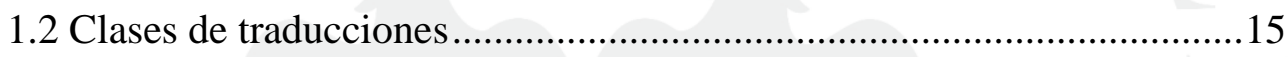

1.2.1 Clasificación de las Traducciones ..................................................18

1.2.2 Clasificación jurídica de las traducciones .......................................19

1.2.3 Traducciones que conllevan fe pública: .........................................19

1.2.4 Traducciones que no conllevan fe pública o privadas .......................23

CAPÍTULO II: SOBRE LA TRADUCCIÓN ESPECIALIZADA .....................29

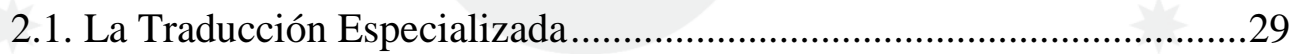

2.1.2 La Traducción Jurídica .................................................................33

2.1.3 ¿Cómo se hace una Traducción Jurídica?...........................................36

2.2 Traducción Jurídica y Derecho Comparado .........................................40

2.2.1 Problemas lingüísticos .........................................................41

2.2.2 Problemas jurídicos .............................................................4

CAPITULO III: LAS TRADUCCIONES Y EL OSCE ..................................46

3.1 Uso actual de las traducciones en el mercado ....................................46

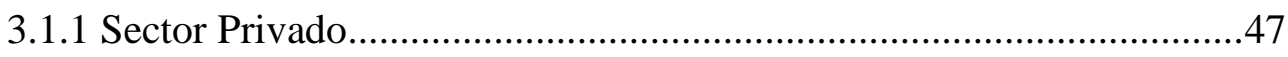


3.1.2 Sector Público .48

3.2 La regulación de las traducciones ante el Osce ....................................49

3.2.1 Decreto Supremo $\mathrm{N}^{\circ}$ 184-2008-EF ...............................................50

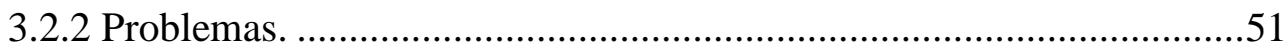

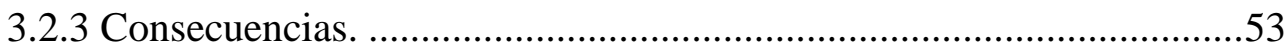

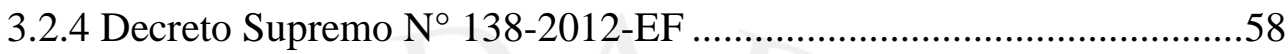

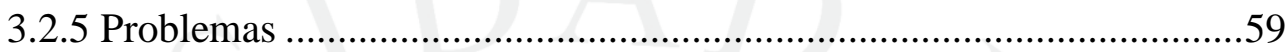

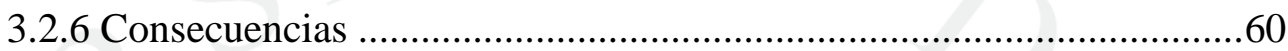

3.2.7 Decreto Supremo N ${ }^{\circ}$ 080-2014-EF .................................................62

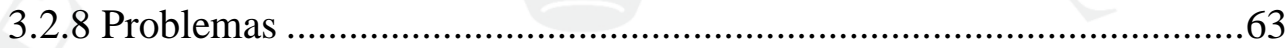

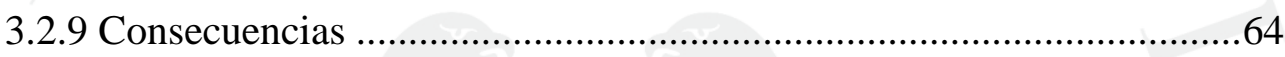

3.2.10 Decreto Supremo N ${ }^{\circ}$ 350-2015-EF .................................................64

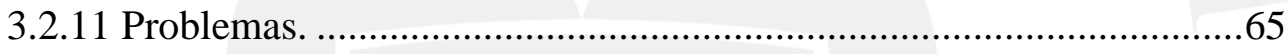

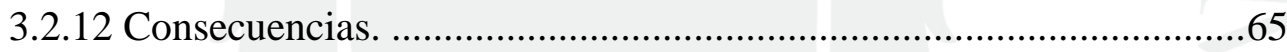

3.2.13 La posición del OSCE sobre las traducciones ..................................65

3.3 Alternativas de solución a los problemas presentados .........................70

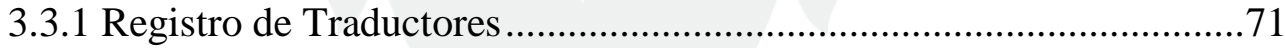

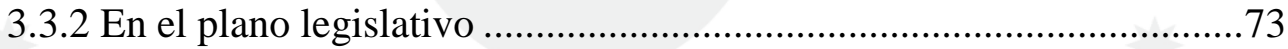

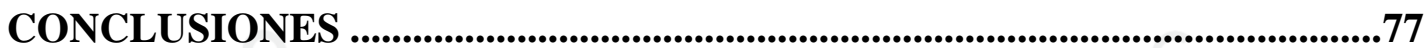

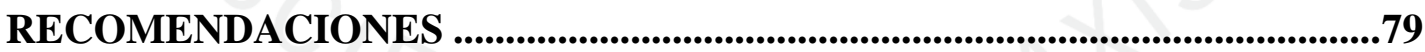




\section{ÍNDICE DE ANEXOS}

Anexo 1: Traducciones especiales.........................................90

Anexo 2: El expediente Fujimori ... .......................................93

Anexo 3: Campaña contra la traducción oficial (i) ..............................95

Anexo 4: Campaña contra la traducción oficial (ii) .............................97

Anexo 5: Proyecto de ley de creación del registro del traductor e intérprete

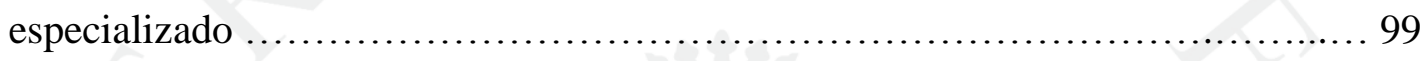


THE LAW IS A PROFESSION OF WORDS DAVID MELLINKOFF (Abogado Norteamericano)

\section{A LA MEMORIA DE EDUARDO PRAELI}

UN PADRE, UN AMIGO 


\section{INTRODUCCIÓN}

\section{Planteamiento del problema:}

Una de las consecuencias que ha traído consigo la tan mencionada globalización ha sido el incremento exponencial de los trabajos de traducción e interpretación. En efecto, hace 20 años aproximadamente tales trabajos tenían una demanda modesta. Sin embargo, en la actualidad la demanda no es solo requerida por los particulares sino también por las entidades públicas, y a todo nivel.

Ante dicho cambio, el legislador se ha visto en un aprieto, no ha sabido cómo regularlos. Una primera respuesta ha sido la de apelar a los traductores del Ministerio de Relaciones Exteriores ante la ausencia de otros profesionales, pero su número limitado y los pocos idiomas ofrecidos (09) ante la inmensidad de posibilidades pronto resultaron insuficientes. Al mismo tiempo, algunas universidades e Institutos ya ofrecían dicha disciplina la misma que concluyó con la creación del Colegio de Traductores del Perú (CTP) igualmente con una oferta muy limitada (07 idiomas).

Dos problemas adicionales se presentaron en este escenario: la falta de especialización de los traductores y la falta de material de consulta los mismos que no han sido resueltos de manera integral a la fecha. Sin embargo, la iniciativa privada está intentando solucionar los problemas aludidos con la constitución de entidades privadas vinculadas a dicha actividad. Ello ha producido conflictos bastantes agresivos de los que tradicionalmente ofrecían estos servicios al sentirse titulares de dicha disciplina. Mientras tanto, el mercado sigue sufriendo las consecuencias de una desacertada regulación lo que de alguna manera se han ido resolviendo con el pasar de los años.

Sin embargo, es pertinente recordar que efectuar la labor de traductor o intérprete no requiere necesariamente de un estudio formal, sino que cualquier profesional en otro campo puede efectuarlo si tiene el conocimiento suficiente de los idiomas implicados, especialmente en el caso de los textos especializados. 
La razón de no restringir la labor de traducir solo a los que han optado por una preparación formal es el alto costo que toma la especialización de un traductor en un área específica y también por ser grande la demanda de traducción especializada.

Uno de esos nichos ha sido el campo de las Contrataciones del Estado. En una primera instancia el legislador había dispuesto que los postores solo pudieran presentar las denominadas traducciones oficiales, para luego pasar a las denominadas traducciones certificadas de los agremiados al CTP, y finalmente disponer la presentación de las denominadas traducciones simples.

Ante la gran complejidad de la tarea y la ausencia de bibliografía nacional, solo nos hemos abocado a la problemática de las traducciones en el área de las Contrataciones del Estado debido principalmente a su importancia económica y al gran número de transacciones que ello implica. Esperamos aportar algo en ese sentido.

\section{Formulación del problema:}

¿De qué manera el Derecho ha reaccionado frente al inusitado incremento de la demanda de traducciones tanto por parte del sector privado y público, en especial en el campo de las Contrataciones del Estado?

\section{Hipótesis:}

El legislador ha optado inicialmente por dar preferencia a los traductores del Ministerio de Relaciones Exteriores para que sean los únicos que puedan efectuar las traducciones que van a ser presentados en los procesos de Contrataciones del Estado, pero debido a las dificultades ocasionadas se ha visto forzado a variar su posición. La explicación es que el legislador no está debidamente informado acerca de la disciplina de la traducción.

\section{Variables:}

- Estudios formales en traducción.

- Diversidad de traducciones ofrecidas en el mercado.

- Traducción especializada. 


\section{Objetivo General:}

Realizar un estudio fundamentalmente teórico que permita conocer las razones por las cuales la Administración Pública en general y la legislación sobre Contrataciones del Estado en particular, han optado por exigir la presentación de las traducciones efectuadas por los traductores del Ministerio de Relaciones Exteriores y en alguna medida por los traductores del Colegio de Traductores del Perú, dejando de lado a los demás traductores. El estudio mencionado incluye el análisis de las normas expedidas a este respecto complementada con algunos aportes del Derecho Comparado.

\section{Objetivos Específicos:}

- Aclarar los conceptos errados que se tienen sobre la disciplina de la traducción,

- Hacer una evaluación de las normas que regulan la traducción en el país,

- Seleccionar las normas que deben ser indispensables para la aplicación en el campo de la traducción,

- Analizar la posición del Organismo Supervisor de Contrataciones del Estado (OSCE) con relación a la problemática de las traducciones, así como presentar nuestras propuestas para que la percepción de dicha disciplina sea uniforme.

\section{Justificación:}

Teórica: El presente trabajo pretende llenar un vacío en la literatura jurídica sobre cómo tratar los documentos que vienen redactados en otros idiomas de manera que los postores cuenten con la seguridad de que dichas traducciones no darán lugar a la sanción de dichos postores. En efecto, no existen trabajos en nuestro país sobre la materia que se hayan efectuado con anterioridad hasta donde tenemos información.

Práctica: Es necesario que los distintos operadores del Derecho estén debidamente informados sobre cómo lidiar con documentos o personas que se expresen en otros idiomas. En el caso de documentos, para que cumplan la función correspondiente en un proceso de cualquier tipo en general y en los procesos de Contrataciones del Estado en especial. El presente trabajo también puede ser de utilidad para conocimiento de los distintos operadores del Derecho como Jueces, Fiscales, Abogados, entre otros. 


\section{CAPÍTULO I: NOCIONES SOBRE LA TRADUCCIÓN}

\subsection{Aspectos básicos de la Traducción}

Antes de analizar las normas que regulan la traducción en general y las contenidas en la Ley de Contrataciones del Estado (LCE) y su Reglamento aplicables a los procesos (hoy procedimientos) de selección de los que desean contratar con el Estado en particular, es conveniente revisar brevemente algunos conceptos básicos relacionados con la traducción. Lo consideramos necesario para poder entender mejor el ejercicio del traductor en general, pero especialmente el del Traductor Especializado sobre el cual redundarán las propuestas que hacemos en este trabajo. Lo creemos necesario, además, pues hemos caído en cuenta de que existen no sólo imprecisiones sino mucha confusión entre los usuarios en este aspecto. Esto se debe principalmente a que casi no existen trabajos sobre traducción en nuestro país; y sobre la labor del Traductor, la producción nacional desde la perspectiva jurídica es prácticamente nula. ${ }^{1}$

Desde el año 1990 en que empezamos a dedicarnos a la traducción jurídica en especial, tanto en la enseñanza como en su ejercicio, hemos tenido la oportunidad de escuchar a muchas personas decir -entre otras cosas- que la traducción es una actividad sencilla y rápida. Otros creen que existen ciertos recursos (una especie de atajo) que hacen que un texto tenga una traducción fidedigna y otros creen que un texto debe tener una sola traducción. Nuestros interlocutores incluyen a abogados que laboran tanto en la actividad privada como en la Administración Pública, así como a Jueces y Fiscales.

Incluso hay otros que creen que el Traductor Público Juramentado (TPJ) ${ }^{2}$ está capacitado para traducir todo tipo de texto y que no comete errores. En relación a estas apreciaciones dice Camilo Fernández Cozman (2008): “... muchos creen que el traductor es alguien que simplemente tipea el texto en otro idioma. No se dan cuenta de que

\footnotetext{
${ }^{1}$ Tenemos conocimiento solamente de una obra cuya autoría corresponde a la Presidenta de la Academia Peruana de Traducción, Lic. Roxana Cieza Castellano sobre el tema, denominada: Cieza, R. (2012). El perito traductor en el contexto jurídico peruano ( $1^{\mathrm{a}} \mathrm{ed}$.). Lima: Editorial Arkabas S.A.C. Sin embargo la óptica no es estrictamente jurídica.

${ }^{2}$ La gente lo denomina erróneamente como traductor oficial sin mayor conocimiento y es así como es llamado en todas instancias, incluyendo las autoridades.
} 


\section{traducir significa penetrar en las entrañas de un texto para luego construir otro."} (p. 23). (El énfasis es agregado)

Además, existen personas que creen que es igual traducir de manera directa o inversa (es decir, del idioma extranjero al nacional y del nacional al extranjero); otros piensan que la traducción puede ser efectuada de manera eficaz por computadoras; otros que un traductor es igualmente competente en cualquier campo. Evidentemente, eso supone una visión superficial del tema, ya que esa percepción no se condice con la realidad. Finalmente, no siempre se distingue entre traductor e intérprete. ${ }^{3}$ En suma, el desconocimiento es general así como la imagen que se proyecta es distorsionada.

Este desconocimiento incluye, curiosamente, a los mismos traductores. En el año 1998, hicimos una encuesta a los Traductores Públicos Juramentados (en adelante TPJ) en número de 35 de los aproximadamente 70 en ejercicio de la época. Los demás no estuvieron dispuestos a ser entrevistados por diversas razones.

A la pregunta: ¿Cómo definiría a un Traductor Público Juramentado? Solamente 8 dieron una respuesta atendible y 10 dieron una respuesta reveladora de su gran desconocimiento. Los demás tuvieron posiciones que no eran ni muy criticables ni muy acertadas.

Vamos a citar, en primer lugar, 3 respuestas del grupo que consideramos atendibles:

Pregunta: “¿Cómo definiría a un Traductor Público Juramentado?”

Respuesta 1: "Como a un traductor que se ocupa de la traducción jurídica."

Respuesta 2: "Un TPJ es un traductor con reconocimiento oficial para traducir documentos y que sean certificados y reconocidos en el exterior. Con su firma da fe que la traducción es fiel al tenor en idioma original."

Respuesta 3: “TPJ es un traductor que puede firmar y dar fe púbica de una traducción, de un documento oficial solicitado en otro país porque esto es entre países."

Podemos, sin embargo, observar que la Respuesta 2 y 3 de manera equivocada mencionan que los documentos son reconocidos (entendemos con valor oficial) en el exterior cuando en verdad es al revés, su valor oficial se aplica a los documentos que llegan y se actúan

\footnotetext{
${ }^{3}$ Mientras el traductor se encarga de traducir textos escritos, el intérprete lo hace de discursos orales.
} 
solamente en el Perú. A continuación, vamos a citar 5 respuestas del grupo que consideramos desatinadas:

Pregunta: “¿Cómo definiría a un Traductor Público Juramentado?”

Respuesta 1: "Profesional con gran responsabilidad donde la búsqueda y el interés por los idiomas sea un placer y trabajo."

Respuesta 2: "Persona que constantemente se está capacitando por excelencia, que lleva una vida ordenada, tiene gran capacidad en lengua extranjera."

Respuesta 3: "Como alguien con talento y mucha paciencia."

Respuesta 4: "El que tiene el "cartón."

Respuesta 5: "Es una persona que ayuda a otra gente a estar conforme a las leyes del país donde se encuentra, mejora la imagen del Perú ya que procura que se cumplan las normas de los países en los que se encuentran peruanos y no tengan algún problema."

Estamos hablando de traductores oficiales profesionales que han estado en el cargo por lo menos 5 años, ya que el último concurso previo a esta encuesta se realizó a fines del año de 1993.

Los conceptos básicos para empezar a desarrollar nuestro tema son principalmente los referidos al concepto de traducción, el bilingüismo del traductor, los requisitos que debe cumplir cualquier traductor, y en particular, el traductor especializado entre otras consideraciones.

Tal como entendemos el problema y según nos dice la experiencia, la traducción puede ser realizada por cualquier persona lingüísticamente competente, no solo porque no es necesario ningún tipo de estudio formal previo (aunque podría resultar recomendable en algunos casos, por ejemplo, cuando se trata de la investigación u otros quehaceres académicos) si no que cualquier persona lo puede hacer en ejercicio del uso del idioma, el mismo que no es patrimonio de nadie. Esto no quiere decir que la tarea sea sencilla, muy por el contrario, son frecuentes los casos de clientes insatisfechos que alegan una deficiente traducción y son numerosos los problemas insolubles que con cierta 
frecuencia afronta un traductor especialmente en un campo especializado como el jurídico.

No solo no es necesario tener título profesional o técnico alguno. Según los estudiosos del tema, ni siquiera es necesario estudiar teoría de la traducción; así nos lo hacen saber Jean Delisle y Georges L. Bastin (1997):

Así como no es indispensable conocer las leyes del lenguaje para poder hablar, tampoco lo es el conocimiento de las teorías de la traducción para practicar la traducción. Desde siempre, los buenos traductores han aplicado reglas intuitivas de equivalencias funcionales en la elaboración de sus traducciones sin haber tenido que asimilar las leyes 'científicas' de la traducción. (p. 53)

\subsubsection{Definición de Traducción}

Obviamente existen muchas definiciones de traducción, tal como lo señalan Cabrera, Hormann y otros (1991) quienes afirman:

Que son numerosísimas las definiciones que sobre la traducción se han dado desde San Jerónimo hasta nuestros días. Se suma a esta primera dificultad el hecho de que sus autores provienen de diversos ámbitos (traductores, escritores, filósofos, lingüistas, semióticos, teóricos de la traducción, etc.). (p.44)

Dichos autores desarrollan el referido concepto con mayor precisión:

La traducción, como oficio, es una actividad práctica, que es llevada a cabo por un traductor, con fines esencialmente pragmáticos y, en una gran mayoría de los casos, utilitarios. Para ello, el traductor se vale de un cuerpo de principios, conocimientos y aptitudes que le permiten alcanzar su objetivo con mayor o menor éxito. (Cabrera, Hormann, et al, 1991, p. 7)

Esto refuerza la idea que proclamamos, en el sentido que dicho concepto también puede ser estudiado jurídicamente. Pero tal vez la mejor definición para nosotros sea la de la española Amparo Hurtado en una de las obras más recientes sobre el tema. Dicha especialista define la traducción: "... como un proceso interpretativo y comunicativo consistente en la reformulación de un texto con los medios de otra lengua que se desarrolla en un contexto social y con una finalidad determinada." (p. 48)

Toda definición tiene algo o mucho de verdad, pero en lo que todos deben coincidir es que es un medio que sirve para salvar la barrera lingüística entre dos personas 
que hablan distintos idiomas; mejor diríamos, entre dos comunidades que hablan diferentes idiomas.

Sin embargo, es preciso poner énfasis en que la traducción (tomando el término en sentido amplio) no se da sólo entre diferentes lenguas sino incluso dentro de una misma lengua. Esto se presenta cuando dos individuos no comparten el mismo bagaje lingüístico, debiendo la persona que cuenta con un mayor conocimiento lingüístico encontrar las palabras que se adapten a la competencia del que carece su interlocutor, por diversos motivos. Tal vez una mejor descripción de esta actividad sea el ejercicio de parafrasear o el usar otras palabras.

Vista, así las cosas, la traducción viene a ser una actividad intelectual más frecuente y natural de lo que uno puede imaginar. Así ha sido reconocido incluso judicialmente en Estados Unidos, en el caso Rasmussen v. Baker, 50 P. 819, 826 (Wyo. 1897) recogido en la última edición del Black’s Dictionary: “Generally speaking, a translation need not consist of transferring from one language into another; it may apply to the expression of the same thoughts in other words of the same language."4

Por otro lado, las diversas definiciones de traducción reconocen la existencia de un lado interpretativo (hermenéutico) que para nosotros es fundamental no sólo en la traducción, sino en la lectura de cualquier texto y más aún en el caso de textos jurídicos. Por lo demás, no hacemos mayores comentarios por la naturaleza del presente trabajo, sino que dejamos por sentado que nos adherimos a la definición de Amparo Hurtado.

Otro aspecto fundamental y pertinente, es que, en todas las definiciones dadas, que son actuales, resalta el lado práctico del tema. En otras palabras, ser traductor significa tener la capacidad de llevar un mensaje de un idioma a otro, aunque se desconozca o no se pueda describir cómo lo hace, qué mecanismos intervienen en el proceso traductor o explicar por qué se prefiere usar una cierta palabra o estilo en vez de otro. Por ello, traducir es un acto muy personal.

En este punto concordamos con Vinay y Dalbernet citados por Delisle y Bastin (1997) quienes afirman:

\footnotetext{
${ }^{4}$ Traducción propia: "En términos generales, una traducción no se da necesariamente de un idioma a otro; también se aplica a la expresión de las mismas ideas usando otras palabras en un mismo idioma." (Black's Law Dictionary, 2014, p. 1728).
} 
...creemos que al traductor (entendido éste como el traductor profesional) le corresponde sólo reproducir y no intentar describir el proceso; es al investigador, al docente de la traducción, al traductólogo, al que le interesa describir y explicar los procesos que intervienen al reproducir un mensaje en lengua extranjera. (p.40)

\subsection{2 ¿Cómo se hace una traducción?}

Hecha la definición, el próximo paso será dilucidar cómo se realiza una traducción de manera didáctica. A estas alturas lo más importante es tener conciencia de que no existen métodos, y menos un único método o guía que garantice per se una buena traducción.

Por lo tanto, nos debemos atener a ciertos principios o ideas fundantes que la práctica va recogiendo con el paso de los años, que por lo demás son poquísimas, según entendemos, para efectuar una traducción: En primer lugar, se debe tener muy presente lo manifestado por García Yebra: "Una traducción debe decir todo lo que dice el original, no debe decir nada que el original no diga, y decirlo todo con la corrección y naturalidad que permita la lengua a la que se traduce." 5

Sin embargo, es bueno reconocer que muchas veces es pertinente agregar comentarios o notas del traductor en beneficio del destinatario en la otra lengua, en un intento de optimizar la comunicación, buscando, según su criterio, la intencionalidad del autor original de la obra. Igualmente, en no pocos casos hay que seguir las instrucciones del cliente.

Recordemos, por otro lado, que muchas obras jurídicas que hemos estudiado en la Facultad de Derecho tienen esas características, dada la naturaleza del derecho; es decir por la frecuencia de los comentarios de los traductores que aparecen a pie de página, con el fin de explicitar mejor los temas objeto de la traducción. Esto sucede especialmente cuando, como se abundará más adelante, el documento que se traduce pertenece a un sistema jurídico diferente a aquel del que se prevé será su destinatario.

Un segundo principio, es el de la fidelidad. Es decir, en la misma línea de lo anterior; ceñirse dentro de lo posible a lo que dice el texto de origen.

Como se puede observar, lo manifestado son principios-guía que cualquiera puede abordar con mayor o menor éxito.

\footnotetext{
${ }^{5}$ Recuperado de: https://www.quedelibros.com/autor/28534/Garcia-Yebra-Valentin.html
} 
Otro principio que está vinculado a los dos mencionados es la de tener una buena redacción. En este extremo, es bueno decirlo, a veces se sacrifica la redacción para poder interpretar de la mejor manera el "espíritu" del texto.

Por tanto, ceñirse al texto original, buscar ser fiel al mismo y todo ello con una buena redacción, aparecen como los principios o guías que debe seguir todo traductor, lo cual, como se verá más adelante, no siempre se logra del todo.

\subsection{3 ¿Traducción, derecho constitucional?}

Nosotros consideramos que saber cuál es el fundamento de la traducción ayuda mucho en su regulación. No hemos encontrado ningún trabajo nacional en ese sentido. Pero analizando la función de un traductor, nos puede ayudar a ubicarlo.

Muchas veces se ha dicho que el traductor es un puente entre dos culturas pues es esa su función, es la persona que ayuda a salvar la barrera idiomática entre dos personas que hablan diferentes idiomas.

Todo ello no hace sino describir a alguien que actúa como un nexo. Alguien que recoge lo que una persona dice y luego de reformularlo en el idioma del destinatario se lo comunica a dicho destinatario. No es difícil deducir que el rol que cumple es el de un intermediario.

Para nosotros, el fenómeno traslativo se explica de la siguiente manera. El traductor y el intérprete son en esencia intermediarios entre dos personas que se expresan en idiomas distintos. Por tanto, el traductor y el intérprete tienen la función de comunicar el mensaje que proviene de otra persona. Esta obligación es la razón de ser del traductor. El traductor tiene que hacer valer su rol de intermediario para dar a conocer al destinatario lo que dice el emisor, tanto en la interpretación (oralmente) como en la traducción (por escrito).

No se concibe que, en esos casos, el traductor o el intérprete interrumpan el mensaje. Ello sería ir en contra de su razón de ser, así como en el caso de un contrato, un incumplimiento de la obligación que le corresponde. Por tanto, el Traductor, a diferencia de cualquier otra persona, se encuentra obligado a dar conocer a la otra parte lo que dice el texto (oral o escrito) de partida. 
Por ello, su rol es más delicado que el de cualquier persona bilingüe; por lo menos está moralmente obligado a realizar su función, no hacerlo atentaría con la comunicación humana. Es por ello que la función de traducir o interpretar no debe tener ningún tipo de limitación y así lo han entendido casi todos los países en donde no se exige requisito académico alguno para su ejercicio.

Por tanto, la función o la labor del traductor o intérprete no se debe limitar y/o reservar a aquellos que por diversas razones han decidido estudiarlo formalmente sea en una Universidad o en un Instituto. Por lo demás, en los hechos no se llegaría a cubrir todos los idiomas en el mundo (se calcula en la actualidad que existen unos 7,102 idiomas $)^{6}$, cosa que sería de imposible cumplimiento. En ese sentido, la única referencia sobre el aspecto jurídico de la traducción la hemos encontrado en la Revista de la ATA (Asociación Norteamericana de Traductores):

In our country, translation is viewed (for purposes of law) as one branch of the communications arts, and therefore falls under the full protection of the First Amendment to the Constitution. (...) Therefore, translation has remained, and will doubtless remain a so-called "free" or "uncontrolled" profession. ${ }^{7}$

Es decir, la traducción está bajo el amparo legal constitucional referido a las libertades de información, opinión, expresión- y difusión del pensamiento recogido en el Artículo $2^{\circ}$, inciso 4 de nuestra Constitución.

\subsubsection{Bilingüismo}

Uno de los efectos de la Globalización ha sido que nos ha puesto en contacto con personas y con textos de toda especialidad redactados en otros idiomas con una intensidad no vista nunca antes. No es difícil encontrar en cualquier parte del mundo personas que hablan un idioma distinto del lugar en el que se encuentran. Los medios de comunicación masiva (la radio, televisión, la prensa y el internet en gran medida) llegan a lugares lejanos de su lugar de origen. La tecnología moderna nos pone al alcance de un clic, innumerables textos redactados en otros idiomas -principalmente el inglés- e igualmente la existencia

\footnotetext{
${ }^{6}$ Recuperado de: www.ethnologue.com/world

7 Traducción propia: "En nuestro país, la traducción es vista (para fines legales) como perteneciente a las ciencias de la comunicación y por lo tanto cae bajo la protección de la Primera Enmienda de la Constitución (...) Por consiguiente, la traducción ha sido, es y sin duda será una profesión "libre" o "no sujeta a control". (American Translators Association, 1994, p. 162)
} 
de otros medios como la facilidad en el transporte internacional hace que sea mucho más fácil que hace algunos años trasladarnos a otros lugares, lo que nos hace conscientes de la necesidad de dominar otros idiomas.

El dominio de otros idiomas, por tanto, ya ha dejado de ser un signo de status para convertirse en una poderosa herramienta que posibilita a su titular recursos invalorables en tiempo y dinero para tener acceso a diversas fuentes de información antes impensadas. Esto nos hace recordar a Kim Woo-Choong, fundador de la transnacional coreana Daewoo, que decía que algunas personas se quedaban sordas y mudas al salir de sus países. Además, en la actualidad saber un idioma (especialmente el inglés) se da por descontado, hay que saber 2 idiomas adicionales a la lengua materna por lo menos en estos tiempos de ardua competencia y por ello una buena política educativa al respecto es crucial en estos tiempos.

En esa línea, la Conferencia General de la UNESCO celebrada el 17 de noviembre de 1999 propugna "un nuevo orden lingüístico, fundado en el plurilingüismo" y la noticia que apareció en el diario oficial El Peruano al día siguiente, dice -entre otras consideraciones- lo siguiente:

La resolución, encabezada por Guatemala, fue presentada por 18 países, entre ellos Cuba, Chile, Panamá, República Dominicana, Eslovaquia, Ruanda, Tailandia y las Islas Seychelles, y contó con el apoyo de Ecuador, Perú, Bélgica y Vietnam.

El objetivo, explicaron estos 22 Estados miembros, es que el alumno pueda expresarse con facilidad en varias lenguas.

Y más recientemente, tenemos noticias de que la Universidad San Ignacio de Loyola ha optado por una enseñanza enteramente bilingüe (inglés - español) para todas sus carreras convirtiéndose en la primera Universidad con estas características en el Perú, al menos hasta ahora.

Por tanto, la pregunta cae por sí sola: ¿Qué entendemos por bilingüismo? ¿Es bilingüe el que domina todas las habilidades que requiere una lengua o solo algunas de ellas? ¿Deben ser estas habilidades tan iguales a las que posee el hablante nativo? Todas esas inquietudes son fundamentales para el que aspira ser traductor, pero para el ciudadano de a pie parece ser que no hay duda: se piensa que el traductor debe ser completamente bilingüe. 
En primer lugar, coincidimos con Amparo Hurtado en que no existe el bilingüe perfecto, por tanto, el grado de bilingüismo del traductor indica que debe poseer un gran conocimiento de otros idiomas distintos al suyo, pero no en grados que domina el hablante que lo tiene como lengua materna.

Así lo entienden los especialistas en la materia. Por lo tanto, el mito de que el traductor es un bilingüe perfecto no tiene mayor fundamento. Su nivel de conocimiento es algo más modesto, tal como lo entienden los especialistas que a manera de ejemplo citamos: "El conocimiento llamado activo de una lengua extranjera no es una exigencia sine qua non para traducir; ni tampoco un impedimento.” (Delisle y Bastin, 1997, p. 40)

Este rol activo es conocido como performance (relacionado con la habilidad de producir discursos o textos) y el rol pasivo como competence (que tiene que ver con la comprensión de dichos discursos o textos). En consecuencia, esto llevado al campo de traducción, quiere decir y citamos: "Por consiguiente, el bilingüe tiene un conocimiento de 'performancia' completo de la lengua extranjera mientras que al traductor le basta con un conocimiento de competencia." (García Yebra, 1983, p.101)

En otras palabras, el traductor no necesita ser un virtuoso en todos los aspectos en ambos idiomas por igual. Es suficiente que tenga la habilidad necesaria para poder captar o comprender bien los textos redactados en otro idioma sea o no extranjero.

En consecuencia, tanto para poder traducir como para interpretar se necesita tener un conocimiento de competencia de un idioma extranjero y poder reformularlo en su idioma nativo. Es claro, además, que si el traductor fuera un bilingüe perfecto ello le facilitará su labor. Por tanto, el traductor debe ser muy hábil en su idioma materno ya que tiene mayores recursos u opciones. Sobre esto afirma el maestro García Yebra:

No puede ser buen traductor quien no sea maestro en su propia lengua. El traductor ideal no es el bilingüe perfecto, que, por lo demás, no existe. Ya que el conocimiento perfecto de una sola lengua es difícil, más aún, inasequible, porque la lengua es un ente vivo, que está siempre evolucionando. (García Yebra, 1983, p.101)

En suma, el traductor no tiene por qué ser un bilingüe perfecto, pero su conocimiento de los idiomas implicados debe alcanzar niveles de excelencia. 


\subsubsection{Requisitos del Traductor}

Existe otro mito el mismo que señala, que para poder traducir es suficiente el conocimiento de las lenguas implicadas. Este es un conocimiento generalizado. Es decir, para muchos es suficiente el aspecto lingüístico. Debemos resaltar que éste es el aspecto que predomina en las actuales instituciones peruanas donde se preparan a los "traductores profesionales", ya que se dedican casi exclusivamente al aspecto lingüístico. Pensamos que la enseñanza debería tener menos de lingüística y debería ser más pragmática; debe ser menos teórica y más práctica. En la misma línea, se encuentran los estudiosos Delisle y Bastin: "En el curso de traducción, resulta más útil enseñar a utilizar la lengua que transmitir informaciones teóricas sobre la lengua misma. El traductor es un técnico del lenguaje no un lingüista." (Delisle y Bastin, 1997, p. 105)

Sin embargo, el traductor debe ser competente no sólo en el manejo de los idiomas, el traductor debe ir mucho más allá para poder traducir tal como sostiene Amparo Hurtado:

Sin embargo, no basta con los conocimientos lingüísticos: el traductor ha de poseer también conocimientos extralingüísticos: sobre la cultura de partida y de llegada, sobre el tema del que trata el texto que está traduciendo, etc. Los conocimientos extralingüísticos varían según el texto de que se trate (y su dificultad cambia según los conocimientos extralingüísticos que tenga el traductor en cada caso), pero son totalmente indispensables para poder traducir; sin ellos el traductor no puede comprender el texto original ni puede reformularlo debidamente." (el subrayado es agregado). (Hurtado, 2001, p.30)

Creemos que estos argumentos son atendibles y contundentes. Por tanto y en la misma línea indicada arriba, debemos concluir que, para poder realizar una traducción, al aspecto lingüístico se le debe agregar un conocimiento práctico, cultural de la realidad donde se produce el texto. Desde hace muchísimos años así lo reconoce García Yebra:

El tercer conocimiento necesario es el del contenido de la obra. Por grande que sea el dominio del idioma ajeno, por muy hábil que uno sea en el manejo del propio, a cada paso correrá el riesgo de caídas mortales si desconoce el terreno que pisa. No hace falta insistir en esto, bastante claro de suyo. (p. 168)

Por tanto, se debe dar por descontado que no es sólo el aspecto lingüístico (conocimiento del idioma) suficiente para poder realizar una traducción de manera efectiva, sino que 
existe un tercer elemento importantísimo que lo complementa: el conocimiento del campo que se intenta traducir.

En este punto observamos personalmente que en el Perú nos hemos quedado con esa concepción de que es suficiente el conocimiento lingüístico para poder realizar traducciones y es de esta forma como se estudia en la actualidad. Pensamos que con esa política sólo se pueden hacer traducciones generales (textos que no son técnicos) pero tenemos grandes dudas en el caso de las traducciones especializadas y son precisamente traducciones especializadas lo que el mercado demanda.

En suma, los requisitos que debe cumplir todo traductor son tres:

- El conocimiento de su propia lengua.

- El conocimiento de la lengua extranjera.

- El conocimiento del campo que intenta traducir.

\subsection{Clases de traducciones}

Existen muchas clasificaciones en torno a la traducción. En nuestro caso, vamos a tomar como referencia el primer paso que da un traductor para ejercer su trabajo; es decir, el de la comprensión del texto, el de su lectura. En ese sentido, ponemos de relieve la dificultad que entraña un texto para su comprensión y por tanto, vamos a hablar de los textos especializados y de los no especializados (o generales) en atención del tipo de lenguaje especializado o la terminología usada. Ya Amparo Hurtado comentando a Cabré decía:

Cabré indica que los lenguajes especializados tienen una temática especializada en el sentido de que han sido objeto de un aprendizaje especializado, que los usuarios son especialistas y que las situaciones de comunicación son de tipo formal, reguladas normalmente por criterios profesionales o científicos. (p.60).

En el Perú, como ya hemos indicado, se está formando a traductores sin ninguna especialización conocida y eso ya está desfasado, no tiene sustento sólido, sus egresados salen al mercado sin un mayor bagaje académico, sin mucho que ofrecer. Y es precisamente en los momentos actuales de globalización y de intenso tráfico documental internacional, en que aparece como una necesidad impostergable el dominio de ciertas áreas, ante la imposibilidad de que una sola persona sea igualmente competente para poder realizar traducciones en cualquier campo con la misma eficiencia. 
Esta necesidad de especialización ya es patente en el Perú y ello explica por qué otros profesionales que no son traductores de carrera realizan traducciones como actividad complementaria, como los casos que menciona Jean Herbert: «Celui qui est aviateur, juriste, statiscien, médecin, etc. et connait la terminologie technique plus ou moins spécialisé de sa profession dans diverse langues será très recherché pour les conférences traitant plus ou moins professionnellement de ces sujets. ${ }^{8}$

Además, esta urgencia de especialización, en otros lugares ya se ha resuelto hace mucho, a decir de Anabel Borja:

La formación de traductores especializados es una exigencia social que las universidades españolas ya han asumido. Los tiempos en los que el oficio de traductor estaba reservado a los escritores de renombre, los eruditos o los poetas han quedado atrás y, hoy en día, el volumen de traducción especializada que demanda el mercado supera con creces la demanda de traducción literaria o poética. (p. 2)

Se puede afirmar, sin temor a equivocarnos, que en la actualidad existe mayor demanda de traducciones especializadas en campos distintos de la literaria. Por tanto, sin agotar la clasificación, consideramos a grandes rasgos que por su especialidad -aparte de la literaria- los traductores se enfrentan generalmente a textos técnico-científicos y a textos jurídico-financieros. Esta clasificación ya se da también en algunos países latinoamericanos, tal como afirman Martínez y Guilman: "En la República Argentina, la profesión de traductor tiene dos vertientes: por un lado la carrera de traductor literario y técnico-científico, que es un estudio de carácter terciario.” (p. 1)

Se debe precisar a estas alturas que en la Argentina el Traductor Público es un egresado de las Facultades de Derecho principalmente. Continúan las autoras antes aludidas:

La otra rama de la profesión es la de traductor público, que es similar a la que en algunos países se conoce como traductor jurado. Esta es una carrera universitaria, que se ofrece en catorce universidades, entre nacionales (o estatales), y privadas. (p. 1)

Vista, así las cosas, habría que dejar en claro que los traductores públicos (según terminología argentina) son en realidad especialistas en Traducción Jurídica. En otras

\footnotetext{
${ }^{8}$ Traducción propia: «Aquel que sea aviador, abogado, estadístico, médico, etc. y conozca la terminología técnica más o menos especializada de su profesión en diversas lenguas, será muy buscado para conferencias que traten estos temas de manera bastante profesional.» Herbert, J. Manuel de l'interprète. Genève: École d'interprètes, p. 92.
} 
palabras, el Traductor Público Juramentado (terminología peruana) es en esencia un traductor jurídico.

El traductor jurídico es, por supuesto, el profesional que se encarga de textos producidos en el mundo jurídico, el cual tiene su propia problemática y terminología. Así lo reconoce uno de sus desaparecidos cultores en Canadá, el jurista Jean Kerby:

Chaque discipline, chaque branche de la connaissance a sa propre terminologie. Le droit ne fait pas exception à cette règle. La terminologie juridique est une langue technique à l'intérieur de la langue usuelle. Il arrive que, dans certaines disciplines relevant généralement des sciences exactes, la traduction d'une langue à une autre pose peu de problèmes sérieux. Tel n'est pas le cas en terminologie juridique, lorsque la traduction comporte non seulement le passage d'une langue à une autre, mais encore la transposition du message d'un système de droit à un autre. ${ }^{9}$

Las razones son bien explicadas por Anabel Borja, cuando señala:

En nuestra opinión, el traductor jurídico debe tener necesariamente un cierto dominio del campo temático del derecho por dos razones fundamentales: en primer lugar por la complejidad conceptual de los textos legales y en segundo lugar por las diferencias entre sistemas jurídicos que hacen difícil, y a veces imposible, encontrar equivalencias. (Borja, 1997, p. 8).

Por eso, ya es tiempo que los estudiantes comiencen a especializarse con miras al futuro y/o dejar que profesionales de otras áreas realicen las denominadas traducciones especializadas como suceden en los países adelantados, agregamos nosotros. Como dice Estévez: “... ésta [la especialización] debe hacerse teniendo en cuenta las necesidades de la sociedad, pero no las tradicionales, ni siquiera las actuales, sino a medio y largo plazo." (Estevez, 1999, p. 410)

Más adelante se reafirma:

Esto es lo que se intenta ahora tímidamente en muchos centros de formación de traductores en donde, además de una formación como traductor, se aportan unos principios básicos en los campos económico - jurídico - comercial y científico-técnico

\footnotetext{
${ }^{9}$ Traducción propia: «Cada disciplina, cada rama del conocimiento tiene su propia terminología. El derecho no constituye una excepción a esta regla. La terminología jurídica es un lenguaje técnico dentro de la lengua usual. Resulta que en ciertas disciplinas relacionadas con las ciencias exactas, la traducción de una lengua a otra no presenta mayores problemas. Ese no es el caso de la terminología jurídica, en el que la traducción no es solo el traslado de una lengua a otra sino el traslado de un sistema jurídico a otro.» (KERBY J., 1982, p. 5).
} 
que están dirigidos a familiarizar, aunque sea mínimamente, al alumno con esos amplísimos campos en los que se generará (y se está generando ya) la mayor cantidad de volumen del futuro trabajo. (Estevez, 1999, p. 410)

\subsubsection{Clasificación de las Traducciones}

Existen diversos criterios para hacer una clasificación de las traducciones. Un ejemplo ilustrativo es aquel que distingue los tipos de traducciones según la dificultad en:

i) Traducciones generales. Realizadas por personas que aparte de sus virtudes lingüísticas, no tienen una especialidad conocida. Las traducciones son de textos que no son técnicos.

ii) Traducciones especializadas. Realizadas por personas que además de sus virtudes lingüísticas cuentan con una especialidad en cualquier campo del conocimiento humano. Algunos ejemplos son el caso de abogados que tienen el cargo de Traductor Publico como Ricardo Chiesa o María Teresa Martínez en Argentina. De igual forma se presentan en Canadá donde las leyes deben tener versiones en dos idiomas (inglés y francés), ya que ambos idiomas son considerados oficiales en dicho país, y por esa razón todas las normas legales deben ser publicadas en ambos idiomas. Los textos son técnicos y complejos.

En esa misma línea están los abogados denominados "Juristas-Lingüistas" los mismos que tienen la responsabilidad de redactar las normas de la Unión Europea en los 24 idiomas oficiales de dicho continente.

Es decir, existen diversos criterios para hacer una clasificación. Otro puede ser según la dirección:

i) Traducciones directas. Aquellas hechas del idioma extranjero al nacional, dicho sea de paso, los expertos consideran que esa debe ser la única forma de traducir, porque es el idioma en el que el traductor, generalmente, tiene un mayor bagaje lingüístico (performance). 
ii) Traducciones inversas. Aquellas hechas del idioma nativo al extranjero. Los que normalmente deben hacerlo los expertos, pero en el mercado hay una gran demanda en esta dirección que los actuales traductores no se abastecen y tienen que derivarlos a profesionales bilingües, aunque no sean traductores de carrera.

En fin, existen muchas otras que no es el caso abordar en este trabajo en el que nos ocupamos principalmente de los grandes grupos.

\subsubsection{Clasificación jurídica de las traducciones}

Las traducciones también son posible de una clasificación jurídica como la que recogemos especialmente de la legislación extranjera. Por tanto, nos permitimos realizar la siguiente clasificación en base a la experiencia, puesto que no existen estudios nacionales al respecto que nos sirvan de guía.

Nuestra clasificación jurídica se basa en un elemento que le sirve de justificación, y en ese extremo pensamos que definitivamente ese elemento debe ser la titularidad de la publica fides, lo que nos ayuda a distinguir a quienes la tienen de los que carecen de ella.

En consecuencia, tradicionalmente las traducciones -jurídicamente hablandodeben ser de dos tipos: las que llevan consigo el agregado de la fe pública y las demás que no la tienen. Es decir, las traducciones oficiales y las traducciones públicas (las mismas que se asumen conllevan fe pública) y las privadas (las que no conllevan fe pública). Así, pasamos a desarrollar dicha clasificación:

\subsubsection{Traducciones que conllevan fe pública:}

\section{a) Traducciones Oficiales.}

Son aquellas traducciones efectuadas por el Estado a través de sus funcionarios o servidores públicos correspondientes. Esto se efectúa generalmente a través de una dependencia abierta al público. Es importante recordar que el autor mediato de dichas traducciones es el Estado y el traductor inmediato son dichos funcionarios. Su denominación más extendida es la de Traductores Oficiales. Esto para fines de 
responsabilidad, llegado el caso. Este tipo de traducciones merece fe pública en razón de haber sido expedidas -como dijimos- por el Estado.

También es pertinente recordar que, dado el carácter no lucrativo del servicio, dichas traducciones tienen un valor fijo expresado en forma de aranceles, dependiendo tanto de la dirección de la traducción (directa o inversa), como del idioma (de los más conocidos a los menos conocidos).

Este tipo de traducciones las tenemos en Chile, y en Costa Rica, hasta donde alcanza nuestro conocimiento. Sin embargo, uno de los defectos que tiene este tipo de servicio es la demora para el cumplimiento con los plazos por parte de la administración pública, hecho que podría justificar su derogación.

\section{b) Traducciones Públicas.}

Son aquellas traducciones expedidas por los denominados Traductores Públicos en el ejercicio de sus funciones, lo que quiere decir que igualmente tienen potestad para expedir traducciones privadas (qui peut le plus, peut le moins).

La diferencia principal con el tipo anterior es que este tipo de traducciones son efectuadas por personas independientes, sean o no traductores de carrera y que sus remuneraciones provienen de sus clientes y no del Estado.

Característica especial de esta traducción, al igual que la traducción oficial, es su pretendida corrección y fidelidad al texto original (presunción iuris tantum), es decir que se trata en principio de un documento cuyo contenido merece fe plena. Sin embargo, el art. $1^{\circ}$ del Reglamento recogido en el Decreto Supremo No 126-2003-RE equívocamente las denomina traducciones oficiales. Nosotros seguiremos con esta denominación solo porque así lo hace la legislación, aunque deberían denominarse públicas.

Es de resaltar que dicho tipo de traducción sólo se puede hacer en documentos que vienen con el visado respectivo del Ministerio de Relaciones Exteriores. Es claro que nos referimos a instrumentos públicos provenientes del extranjero. El trámite para la traducción efectuada por un TPJ es el siguiente:

\section{Traducción de documentos públicos provenientes del extranjero:}


a) De países miembros del Convenio de La Haya sobre la Apostilla:

- Los documentos públicos ingresan con la Apostilla en dicho documento.

- Son refrendados en el Ministerio de Relaciones Exteriores.

- Son llevados ante el Traductor Público Juramentado para su traducción respectiva.

- Son devueltos al Ministerio de Relaciones Exteriores para la legalización de la firma del Traductor Público Juramentado.

b) De países que no son miembros del Convenio de La Haya sobre la Apostilla:

- Son legalizados por el Cónsul peruano en el país de origen del documento.

- Son refrendados en el Ministerio de Relaciones Exteriores.

- Son llevados ante el Traductor Público Juramentado para su traducción respectiva.

- Son devueltos al Ministerio de Relaciones Exteriores para la legalización de la firma del Traductor Público Juramentado

La pregunta es: ¿Qué sucede con documentos que están en idiomas para los cuales no existe TPJ? El Ministerio de Relaciones Exteriores ha dispuesto en ese caso que se apele a las denominadas Traducciones Especiales, que son aquellas que están contempladas en el Art. 52 del D.S. N 126-2003-RE, que dispone:

Art. 52 ${ }^{\circ}$ - En el caso de traducciones del castellano a otros idiomas o viceversa, que no puedan ser efectuadas por no existir Traductor Público Juramentado, merecerá fe pública la traducción realizada por:

a) Embajada acreditada ante el Estado peruano.

b) Universidad que cuente con Facultad de Traducción.

c) Centro de enseñanza del idioma que cuente con personal que pueda traducir.

d) Traductor especializado en el idioma requerido. 
En los casos señalados en los incisos anteriores, la traducción merecerá fe pública cuando sea registrada por la Junta de Vigilancia de Traductores Públicos Juramentados.

Para nosotros esta norma va más allá de la ley de creación del TPJ, pues en ella no se contempla esa equiparación. Es decir, el reglamento va más allá de la ley que pretende normar, pero lamentablemente la Administración Pública no puede efectuar el control difuso de la norma como sabemos (así lo dispuso el Tribunal Constitucional en la Sentencia $N^{\circ}$ 4293-2013-PA/TC). Pero, si por algún motivo el caso llegara al Poder Judicial, lo cual es perfectamente factible, entonces sí se podrá cuestionar dicha norma.

\section{Traducción de documentos privados provenientes del extranjero:}

Éstos solo serían traducidos oficialmente (según terminología usada actualmente) si tuvieran las legalizaciones de ley. Pero como no es así, se tendrá que efectuar la traducción sin los sellos oficiales, lo cual tendrá el mismo valor que una traducción no oficial o lo que es lo mismo, efectuada por cualquier persona.

Esta viene a ser una de las limitaciones que tiene el cargo de TPJ a nuestro entender, pues lo que se desea saber es el mensaje del texto y no la naturaleza o la procedencia del documento, por tanto, no llegamos a entender por qué la restricción en este extremo. En otras palabras, un documento privado (el mismo que no tiene por definición ningún tipo de legalización) no podrá pasar por traducción oficial. Esto se agrava si pretendemos presentar dicho documento en un litigio ante el Poder Judicial ${ }^{10} \mathrm{o}$ ante la Administración Pública, dichas entidades lo rechazarán como ha sucedido en varias ocasiones por no haber sido traducido de manera oficial por un TPJ, o sea, lo que dice el texto queda relegado a un segundo plano, cuando éste debería ser el objetivo último de la función del traductor público.

En cuanto al nomen juris, no hay claridad en cuanto a su denominación. En nuestro país tanto su ley de formación, Decreto Ley $N^{\circ} 18093$, como su modificatoria, el

10 “Art. 241.- Documentos en otros idiomas.

Los documentos en idioma distinto del castellano serán acompañados de su traducción oficial o de perito comprendido en el artículo 268 , sin cuyo requisito no serán admitidos.

Si la traducción es impugnada, el impugnante debe indicar expresamente en qué consiste el presunto defecto de traducción. En tal caso el juez debe designar otro traductor, cuyos honorarios los pagará el impugnante. Si la observación resultara maliciosa, se impondrá una multa.” (Código Procesal Civil). 
Decreto Legislativo $\mathrm{N}^{\mathrm{o}} 712$, no la contiene. Sin embargo, se le menciona erróneamente, como adelantáramos, en el Art. $1^{\text {o }}$ del D. S. N ${ }^{\circ}$ 126-2003-RE. ${ }^{11}$ Aquí el referido decreto incurre en grueso error como dijimos al calificar a las traducciones efectuadas por los TPJ como "oficiales" cuando debió haber dicho "traducciones públicas" en concordancia con la denominación del cargo.

En el derecho comparado encontramos otras denominaciones mejor planteadas tales como Traducciones Juradas (España) o Traducciones Públicas (Argentina); preferimos ésta última pues denota con mayor precisión su naturaleza. Igualmente consideramos que el término "juramentado" es complementario o sinónimo de público, debido a que el TPJ recién incorporado debe prestar juramento antes de empezar a ejercer el cargo. Por ello, no alcanzamos a comprender lo que manifiesta la traductora Luisa Pastore-Alinante en un artículo escrito en la página web de la Asociación de Traductores Profesionales del Perú (ATPP) a propósito de un episodio con un cliente. Dice Luisa Pastore-Alinante (2010): "Fue en esta época que un cliente me solicitó una traducción juramentada que, sin embargo, no debía ser oficial, pues no quería que llevara el sello de “Traducido sin legalizaciones oficiales". (párrafo 14)

Esto es un contrasentido, puesto que legalmente hablando el término juramentado tiene el alcance que comentamos. En otras palabras, el pedido de dicho cliente es un imposible jurídico. Es como pedir una traducción oficial que no sea oficial.

\subsubsection{Traducciones que no conllevan fe pública o privadas}

Nosotros denominamos Traducciones Privadas a aquellas que no tienen la calidad de públicas u oficiales. Para empezar -tal como dijimos líneas arriba- los mismos TPJ pueden efectuar TRADUCCIONES PRIVADAS en mérito al artículo $1^{\circ}$ de su Reglamento que les da la alternativa de prescindir de los Sellos Oficiales en caso de documentos privados.

Pero, por distintos motivos que no nos toca juzgar, existen en el mercado diversos tipos de traducciones para todos los gustos y lo único que se ha conseguido es confundir

11 “Art. $1^{\circ}$.- Los Traductores Públicos Juramentados cumplen la función de efectuar traducciones oficiales escritas de documentos en dos direcciones: de un idioma extranjero al idioma castellano (traducción directa) y del idioma castellano a un idioma extranjero (traducción inversa). Un Traductor Público Juramentado podrá serlo en uno o más idiomas y en una o más direcciones." 
al público usuario. Entre las más conocidas podemos encontrar a la Traducción Simple; la Traducción Certificada; la Traducción Acreditada; la Traducción Especial y hasta se habla de una Traducción Juramentada; no descartamos que existan otras (el ingenio peruano es fecundo para estas cosas). Pero todas ellas comparten la misma característica: la de no contener fe pública, por tanto, caen automáticamente en la categoría de traducciones privadas, terminología que nos parece más apropiada y conveniente por su naturaleza y porque se antepone y se distingue de lo público u oficial.

Ahora procederemos a describir cada tipo de traducción, pues cada una debe tener alguna característica que explique o intente explicar su razón de ser, para saber a qué obedece su denominación.

a) Traducciones Simples.- Esta es la forma que usa la ley para denominar a las traducciones que no provienen de un TPJ. En esto no tiene nada que ver la firma puesta en una traducción, tal como pretende nuevamente Luisa Pastore-Alinante cuando menciona que la traducción simple "es la que no lleva firma" con lo cual discrepamos en el extremo de que lleve o no la firma de su autor no altera su valor o naturaleza.

Citamos nuevamente a Pastore-Alinante (2010): “... la traducción "simple”. Esta última, todos lo sabemos, es la que no lleva la firma de su autor." (párrafo 6)

Sin embargo, la ley misma dice todo lo contrario al exigir que las traducciones simples tengan los datos del traductor (incluyendo firma) como en el caso del artículo $41^{\circ}$ de la Ley $N^{\circ} 27444$ o Ley del Procedimiento Administrativo General. ${ }^{12}$

Por tanto, tradicionalmente la ley ha usado la denominación de traducción simple para indicarle al usuario que prescinda de los servicios de un TPJ, especialmente por cuestiones económicas.

b) Traducciones Certificadas.- Según el Colegio de Traductores del Perú este tipo de traducciones son una "novedad" para calificar a las traducciones que son expedidas por cierto grupo de sus colegiados. No sabemos qué se pretende con

12 Art. 41. Documentos

41.1. Para el cumplimiento de los requisitos correspondientes a los procedimientos administrativos, las entidades están obligadas a recibir los siguientes documentos e informaciones en vez de la documentación oficial, a la cual reemplazan con el mismo mérito probatorio:

(...)

41.1.2 Traducciones simples con la indicación y suscripción de quien oficie de traductor debidamente identificado, en lugar de traducciones oficiales. (el subrayado es agregado). 
dicha medida, ya que supuestamente quienes las hacen cuentan con una Licenciatura, la misma que probaría su capacidad para efectuar traducciones.

Lo curioso de todo ello es que en la práctica ya existían desde hace mucho tiempo las denominadas "Traducciones Certificadas". En esto sí acierta Luisa Pastore-Alinante (2010), la supuesta Traducción Certificada tiene antigua data; dice la traductora:

El nombre de 'traducción certificada` fue adoptado y difundido posteriormente por María del Carmen Pizarro cuando ella también asumió el cargo en 1982, pero en la modalidad de firma sobre papel membretado de su empresa de servicios de traducción. (párrafo 23)

Por ello, podemos sentenciar que no es novedosa, por donde se le mire. Pero no solo eso, sino que pretende que se dé una ley para su regulación cosa absolutamente innecesaria. Dice Pastore-Alinante nuevamente:

... la diferencia entre la traducción certificada y la Traducción Oficial era que la primera no contaba (y no cuenta hasta el día de hoy) con el respaldo de una ley que le diera el valor obligatorio de prueba prima facie erga omnes. Esta diferencia existe hasta el día de hoy, pues no ha sido promulgada ninguna ley que regule la traducción certificada definiendo el alcance de su validez o la modalidad de acreditación que un traductor necesita para certificar sus traducciones. (párrafo 24)

Esto tampoco tiene sentido, un documento merece fe o no. No hay término medio. La pregunta sería, si las traducciones de los TPJ conllevan fe pública, ¿qué característica tendrían las traducciones certificadas? Si tienen igualmente fe pública, entonces su ley estaría derogando la ley de los TPJ; si no tienen fe pública, entonces no requieren de ninguna ley para su actuación, tal como sucede hoy. Por ello es claro que nuestra denominación tiene mayor sentido: Traducción Pública (conlleva fe pública) contra Traducción Privada (carece de fe pública).

Para terminar con este punto, solo nos queda decir que no existe (y por lo visto no podrá existir) una norma que le dé sustento a una "Traducción Certificada" ya que solo existen dos tipos de certificaciones: i) Las certificaciones (oficiales o públicas) efectuadas tanto por los Traductores Oficiales como por los Traductores Públicos tal como son reconocidas en los países que tienen esta figura, ii) Las certificaciones (privadas) efectuadas por todo aquel que ejerza el oficio de traductor. 
Para nosotros dicha denominación de "certificadas" a secas puede deberse a que la denominación proviene del inglés "certified translation" habida cuenta que en los países del Common Law no existen traducciones públicas u oficiales y es a través de este tipo de traducciones (certified translation) que se le da cierta formalidad o credibilidad al documento, pero que resulta ajeno a nuestro ordenamiento. Por ello, empezamos a sospechar que la famosa traducción certificada no es más que un falso amigo como dirían los teóricos de la traducción.

El desarrollo de la certified translation en los países anglosajones ha sido de la siguiente manera: En un primer momento el traductor, una vez terminada su tarea, llevaba dicha traducción con sus datos ante un Notario quien verificaba la identidad de la persona quien al mismo tiempo prestaba juramento que dicha traducción era "fiel y correcta" al original.

En un segundo momento, la certified translation se realizaba sin la presencia del Notario. Solo se le agregaba los datos del traductor para su debida identificación.

En un tercer momento la certified translation solo indica que dicho traductor ha superado ciertas pruebas de una entidad (pública o privada) y que por lo tanto se supone cuenta con la competencia requerida, lo cual, sin embargo, no es requisito indispensable para el ejercicio de la traducción ni conlleva ningún tipo de agregado relacionada con la fe pública.

Es pertinente señalar que en el Perú se efectúan los 3 tipos de certificación privada, dependiendo fundamentalmente de los requerimientos del usuario.

c) Traducciones Acreditadas.- Vendrían a ser aquellas expedidas por los licenciados universitarios en traducción, que han aprobado los requerimientos de la Academia Peruana de Traducción. Esta ha sido la última creación en estos extremos. No tenemos mayor información al respecto por el momento.

Sin embargo, el calificativo de acreditado nos resulta más sano que el de certificado, dado que acreditado indica que dicho traductor merece crédito pues, en principio, la Academia toma como referencia la Licenciatura del interesado (algo paralelo al del Colegio de Traductores), mientras que el de certificado podría dar lugar (erróneamente) a pensar que dicho Traductor es titular de la fe pública cuando en realidad no lo es.

Producto de esa falsa apreciación ha sido víctima incluso el mismo Ministerio de Relaciones Exteriores que confundió el régimen de las traducciones oficiales con el de 
las "traducciones certificadas", a propósito de una solicitud hecha por el Colegio de Traductores del Perú a dicha entidad con el fin de registrar la firma de la decana del gremio traductor.

Este hecho fue reconocido expresamente en un artículo de la Revista $\mathrm{N}^{\circ} 4$ del Colegio de Traductores del Perú (CTP) donde se dice literalmente:

\section{Ministerio de Relaciones Exteriores legaliza la firma de la decana en las traducciones certificadas.}

La solicitud del CTP se hizo, en vista de que los funcionarios de RR. EE., por desconocimiento, aplicaban a las traducciones certificadas las mismas exigencias que a las traducciones oficiales, es decir, exigían que el documento en idioma de partida fuera un original y que el traductor fuera un traductor público juramentado (TPJ), en lugar de simplemente legalizar la firma de la decana, que fue debidamente registrada en dicho Ministerio tan pronto empezamos nuestra gestión. (Traducteando, $\mathrm{N}^{\circ} 4$, p. 4)

Por tanto, este tipo de traducciones "certificadas" ha demostrado ser peligroso ya que crea confusión en el público usuario como ya demostramos, a menos que sea eso lo que precisamente desean sus promotores. Si ese fuera el caso, la próxima parada de los defensores de dicho tipo de traducción sería INDECOPI ante una eventual denuncia por competencia desleal en la modalidad de engaño.

Finalmente, el hecho de crear un grupo de "traductores colegiados certificados" crea innecesariamente una división (sino antagonismo) con los demás colegiados que no son “certificados". Pero lo paradójico de todo esto es que los Traductores Colegiados que no son "certificados" así como cualquiera puede perfectamente expedir las denominadas "traducciones certificadas" haciendo legalizar su firma ante Notario en el peor de los casos.

d) Traducciones Especiales.- Son aquellas que son efectuadas por las personas y/o instituciones recogidas en el art. 52 del Reglamento de los Traductores Públicos Juramentados (D.S. No 126-2003-RE) el cual debe pasar por un largo camino de registros, legalizaciones y certificaciones que alude los artículos 52, 53, 54, 55, 56, 57 y 58 del Reglamento referido ya comentada líneas arriba sobre Traducciones Públicas. (Ver Anexo 1) 
Nosotros pensamos que mejor hubiera sido dejar sobrentendido que en caso de no existir TPJ en el idioma requerido, el interesado podrá utilizar una Traducción Privada bajo responsabilidad tanto del interesado como del traductor.

Afortunadamente, todo esto ha quedado superado parcialmente con la dación de la Ley $\mathrm{N}^{\mathrm{o}} 27444$, al permitir que cualquier usuario pueda utilizar una traducción simple (Traducción Privada) ante cualquier estamento de la Administración Pública. Más aun, la Ley N 27444 deja en el limbo no sólo a las traducciones especiales sino a las mismas traducciones públicas como veremos más adelante.

e) Traducciones Juramentadas.- Y como si ya no fuera suficiente se habla de Traducciones Juramentadas, no sabemos lo que ello significa. Dice nuevamente Luisa Pastore-Alinante en el mismo artículo comentado: "Me refiero a la diferencia entre traducción certificada o traducción oficial (voy a llamarla “juramentada” para indicar conjuntamente las dos) y la traducción "simple". (párrafo 6)

Es claro que este tipo de traducción no tiene identidad propia. Para nosotros esto es un juego de palabras pues se está haciendo referencia a una traducción oficial. Aunque algunas agencias de traducción manifiestan que se trata de una traducción simple expedida por un TPJ y no la denominan simple para diferenciarse de las traducciones simples expedidas por otros traductores independientes. Creemos que ya es tiempo de que se ponga fin al festival de bautizar a las traducciones y/o traductores sin mayor fundamento.

Con esto damos por terminado la descripción jurídica de la validez que tiene una traducción de manera escueta. 


\section{CAPÍTULO II: SOBRE LA TRADUCCIÓN ESPECIALIZADA}

\subsection{La Traducción Especializada}

En la actualidad existe tal cantidad de textos y material de temas específicos para ser traducidos, que los traductores generales ya deben dar paso a los especialistas o tienen que optar desde ya por transformarse en traductores especializados. La misma apreciación la tiene Carlos Estévez Eguiagaray quien dice: "Pienso que existe un desequilibrio entre la formación en campos específicos de los traductores y las necesidades del mercado." (p. 408)

En verdad, hoy en día, ya no se traduce lo que tradicionalmente se hacía: correspondencia epistolar y, en algunos casos, la correspondencia comercial, que dicho sea de paso, podía ser hecha por la secretaria de la oficina o por un trabajador de la empresa. Hoy en día, los requerimientos del mercado son más exigentes. Se trata de textos y de documentos que exigen mucho conocimiento del tema y esto ya excede de lejos la competencia de un asistente secretarial, sin importar que tan versado sea en otro idioma. Son textos muy complejos que en manos equivocadas pueden y -de hecho- han causado mucho daño.

En esta línea, nos llega la información de un evento realizado en la Habana, Cuba precisamente sobre traducción especializada que nos confirma que hay una preponderancia de textos especializados sobre los textos generales. La deducción es sencilla, en el caso de textos generales cualquier persona con un conocimiento promedio de idiomas puede realizar de manera más o menos aceptable la traducción correspondiente, mientras que en el caso de textos especializados hay que recurrir a un profesional competente en la materia y es eso justamente lo que demanda actualmente el mercado de las traducciones. Se afirma que, en el mercado mundial de cada 10 páginas para traducir, 9 son textos especializados; pero tomemos la cita del evento mencionado:

9/10 pages traduites sont spécialisées. 
La Traduction spécialisée représente près de $90 \%$ du volume de traduction mondial.

Les traducteurs spécialisés traduisent des documents écrits de toutes sortes, produits principalement par des entreprises, mais aussi par des institutions et organismes internationaux: par exemple, des documentations sur des produits, des notices et modes d'emplois, des contrats et conventions, des ouvrages de vulgarization et des manuels, des sites Web, des Cédéroms ainsi qu'une grande quantité de logiciels. ${ }^{13}$ (Congreso Mundial de Traducción Especializada, 2008, p. 23)

Esto nos trae a la memoria el caso de la traducción al japonés del expediente Fujimori. Tal como informara CARETAS, 2002, bajo el título de "ENROQUE NIPÓN" el trabajo recayó en la empresa Learning. La falta de especialización de la traductora de dicha empresa fue la razón del rechazo del gobierno japonés, el mismo que fue devuelto por deficiencias, entendemos, por no haber sido adaptado al sistema japonés. (Ver Anexo 2)

Por otro lado, se puede sostener con facilidad que la gran mayoría de textos son en inglés, habida cuenta de su consolidación ya no solo como el idioma de los negocios, sino que se considera que tiene condición de lingua franca también para la Comunidad Jurídica Internacional. Siguiendo las mismas líneas de las Actas del Congreso Mundial sobre dicho tema de los idiomas, se puede leer:

Comme il est aisé de l'imaginer, l'anglais, de par son statut de langue internationale, est bien évidemment la langue la plus traduite dans le monde. Plus de la moitié des traductions se réalise depuis cette langue. Suivent ensuite, dans une bien moindre mesure, le français, l'allemand, le russe, l'italien, l'espagnol et le suédois. ${ }^{14}$ (Congreso Mundial de Traducción Especializada, 2008, p. 23)

En cuanto a la segunda razón, desde hace años, especialmente desde inicio de la década del 90, se puede apreciar un incremento notorio del tráfico documentario a todo nivel especialmente en inglés- y este incremento no ha cesado, por el contrario sigue su ascenso

\footnotetext{
${ }^{13}$ Traducción propia: " $9 / 10$ páginas traducidas son especializadas.

La Traducción especializada representa cerca del $90 \%$ del volumen de la traducción mundial. Los traductores especializados traducen documentos escritos de todo tipo, principalmente de empresas, pero también de instituciones y organismos internacionales; por ejemplo, de documentos sobre productos, noticias y modos de empleo, de contratos y convenciones, de obras de difusión y de manuales, sitios Web, CDroms al igual que de una gran cantidad de software." CONGRESO MUNDIAL DE TRADUCCION ESPECIALIZADA. La Habana, Cuba. 8-13 de diciembre de 2008. En:http://unilat.org/Library/Handlers/File.ashx?id=5154ac8d-935d-4611-9c93-de7fb898ff09 p. 23.

${ }^{14}$ Traducción propia: "Como es fácil de imaginar, el inglés por su condición de lengua internacional, es el idioma más traducido del mundo. Más de la mitad de las traducciones se realizan a partir de este idioma. Le siguen a una distancia considerable, el francés, el alemán, el ruso, el italiano, el español y el sueco.” CONGRESO MUNDIAL DE TRADUCCION ESPECIALIZADA. p. 23.
} 
de manera exponencial de tal manera que circunstancias como la apertura de los negocios internacionales, las bondades de los tratados de libre comercio y el aumento del número de personas que se trasladan de un país a otro, así como los innumerables problemas que puede provocar la inmigración de personas, especialmente por razones de trabajo a países que hablan otros idiomas, entre otras circunstancias, implica demanda de traductores e intérpretes. Por tanto, la figura del traductor -sea o no público- seguirá creciendo a medida que se acorten las distancias y se optimice la tecnología informativa.

Esto ha hecho decir a García Yebra en el siglo que nos acaba de dejar: "Lo que ha cambiado, lo que ha crecido enormemente en este siglo, sobre todo en sus cuatro últimos decenios, y sin duda seguirá creciendo a un ritmo acelerado, es la importancia de la traducción y, por consiguiente, del traductor.” (p. 10)

Este hecho también se ha evidenciado en el ejercicio del traductorado público peruano. Cuando nació el cargo de Traductor Público Juramentado (TPJ), había "vacantes" sólo para 10 personas a lo mucho y a nivel nacional. Hoy, sin embargo, la ley admite que este cargo es ilimitado (Art. 1 del Decreto Legislativo $\mathrm{N}^{\circ} 712$ ab initio). Sin embargo, el Ministerio de Relaciones Exteriores se niega a convocar a concurso según ley por razones desconocidas, pero afortunadamente para los traductores independientes y otros expertos, la figura de la traducción oficial tiene frágiles cimientos por lo que pronosticamos su desaparición.

La primera consecuencia de este desborde documental mencionado, ha sido la aparición de textos especializados. Es decir, al acortarse las distancias sean físicas o no, se ha caído en cuenta de la necesidad de actualizarse o simplemente de comunicarse. Producto de esta necesidad, que ya no solo es preocupación de las empresas de comercio internacional, ha sido la demanda de traductores especializados.

Esta demanda ha tomado por sorpresa a los traductores generalistas que ya han terminado su preparación regular, pero no han previsto dicha demanda y se han visto en la necesidad de empezar a especializarse, pues no han tenido los instrumentos para poder lidiar con los denominados textos especializados.

¿Cómo se puede definir a la traducción especializada? Según los teóricos y/o estudiosos de la materia afirman, existen textos que son producto de una preparación especializada y que dan origen también a una terminología especializada, en principio comprensible solo por aquellos que componen ese círculo de especialistas. 
Por tanto, cada área del conocimiento tiene su propio "lenguaje", tiene su propia terminología. Como consecuencia de ello, asumir que una persona que solo ha estudiado el idioma extranjero a nivel "estándar" -como se hace en la actualidad- pueda ser capaz de comprender y traducir todo tipo de texto especializado que llegue a sus manos es ser ingenuo.

Pero ello tampoco quiere decir que todo traductor deba ser al mismo tiempo profesional en cada área del conocimiento (aunque en todas partes se reconoce que sería lo ideal). Lo que se quiere decir es que opte por ciertas áreas que por sus características sean más propicias para empezar a especializarse, aunque reconocemos que les tomará mucho tiempo. Ello explica por qué en los países adelantados prefieran a un profesional con conocimiento de idiomas para que realice estos trabajos de traducción.

Dicho todo esto, a grandes rasgos se puede decir que existen tres grandes grupos de especialidades en traducción: la traducción literaria, la traducción técnico-científica y la traducción jurídica.

\subsubsection{La Traducción Literaria y La Traducción Técnico-científica}

Tradicionalmente y como lo demuestra la historia, la traducción se ha dado en el campo literario y por ello el traductor tiene la imagen del erudito literario. No solo eso, sino que se ha pensado que una persona dedicada a la literatura, debido a sus conocimientos lingüísticos, estaba en mejor posición que los demás para poder efectuar una traducción sin importar la especialidad del texto. A pesar de ello, en nuestro país la demanda de traducción literaria es prácticamente nula.

Normalmente las traducciones en este campo (literario) se efectúan en el extranjero, especialmente en España. Casi la totalidad de las obras en este campo ya vienen traducidas al país. Igualmente, las obras de nuestros autores famosos no son traducidas en nuestro país sino en el exterior. Por tanto, los usuarios nacionales son aquellas personas que tienen un interés muy particular en esta área. Esto se corrobora por la demanda casi inexistente en este campo.

De esta especialidad se puede decir dos cosas: i) que la traducción literaria es tal vez el campo en el que es más importante el aspecto lingüístico, especialmente en la poesía ya que al ser la literatura expresión de un arte, mucho de ese arte descansa en el lenguaje per se, ii) no hay mayor demanda en este campo que está en manos de literatos 
o especialistas que por razones personales se inclinan por los estudios de lengua y literatura.

En cuanto al campo técnico-científico también presenta dos características muy especiales que se debe destacar: i) es un campo con un léxico abundante y muy puntual, desde ya el traductor en este campo debe conocer la especialidad que es muy frondosa en su terminología, como dijimos anteriormente, ii) existe una demanda importante en este rubro, sobre todo a nivel empresarial, pero como se puede entender hay muy pocos especialistas que puedan atender a plenitud esta demanda.

Por tanto, quienes efectúan este trabajo de manera eficiente en nuestro país son aquellos que tienen estudios en algún campo técnico o de la ciencia. Además, existe una asociación que los agrupa y que cuenta con pocos miembros como se puede comprender. Nos referimos a la Asociación Peruana de Traductores Técnicos-científicos (APETEC) cuyos miembros tienen una profesión distinta a la traducción pero que tienen el activo de dominar otros idiomas y de estar informados sobre traducción.

No profundizamos más en el tema, pues nuestra orientación en el presente trabajo se inclina por lo jurídico, sobre el cual tratamos a continuación.

\subsubsection{La Traducción Jurídica}

El otro gran campo especializado es el jurídico (en verdad, la combinación jurídicofinanciera en mayor medida). Si bien es cierto que el Derecho no usa un lenguaje o simbología diferente del que usan otras ciencias (matemáticas, química entre otros) es cierto también que cuenta con frases y términos muy propios; es decir, una jerga y una terminología muy propia que conlleva un significado particular, el mismo que no es fácilmente asequible al ciudadano de a pie. Tal vez el único trabajo sobre el tema en el país lo ha hecho Carlos Garatea Grau (abogado lingüista) pero que se dedica más a la lingüística que a la traducción.

Por otro lado, este campo es el que representa más del $60 \%$ de la demanda en el mercado (según la agencia de traducción Lexitrans). ${ }^{15}$ Pero hay pocos que se dedican a su cultivo por una verdadera carencia de verdaderos especialistas en los muchos idiomas

\footnotetext{
15 Aviso subido el 28 de junio de 2013 en la web del Instituto de Altos Estudios en Traducción, en: www.facebook.com/pages/IAET-Instituto-de-Altos-Estudios-en-Traducción/315147053304
} 
que se pueden presentar. En verdad, y de paso podemos decir que son poquísimos los abogados que dominan otros idiomas a niveles de excelencia.

El aspecto más saltante de esta especialidad es la compleja terminología de los temas que hace que la literatura jurídica sea difícil de entender. Por ello, es comprensible la existencia de movimientos que tengan como objetivo la simplificación del lenguaje jurídico (Plain Language) especialmente en países donde el mercado de traducción jurídica es inmenso como en los EE. UU.

Por tanto, también en este campo es necesario el conocimiento del tema como afirman los conocedores en el Perú: "Hay que saber traducir con exactitud y precisión. Si le traen una traducción de historia o matemáticas, debe saber sobre la materia, si no, engañaría.” (Tupac Yupanqui, 2008, p. 18)

Sin embargo, como ya sabemos, todas las instituciones que se dedican a la enseñanza de la traducción se preocupan casi exclusivamente por el aspecto lingüístico.

En este aspecto, nos ilustra con sendos ejemplos García Yebra en su obra ya mencionada líneas arriba:

Es casi seguro que un Doctor o Licenciado en Filosofía Clásica traduciría mejor que un Ingeniero Industrial una Historia del Teatro Griego, mientras que el Ingeniero está, en principio, mejor preparado que el Filólogo para traducir un tratado sobre resistencia de materiales o sobre cerebros electrónicos.” (p. 357).

Asimismo, un abogado estará en mejores condiciones que uno que no lo sea para realizar traducciones jurídicas. Sin embargo, esta deficiencia del traductor generalista puede ser suplida con el estudio de ciertas materias pues la preparación del traductor jurídico, a diferencia del abogado, no radica en la aplicación del derecho para la solución de conflictos entre otros fines que tiene el derecho, como la investigación o enseñanza por ejemplo, sino para la adquisición de un bagaje cultural que le ayude a una mejor comprensión de los textos que se le presenten. Al respecto Lane dice:

If the translator is not a trained lawyer, he may not necessarily be able to comprehend the meaning of a text. Therefore, the ability to understand the legal content of a text depends on the amount of preparatory training that the translator has received. The 
ideal translator is one who is an expert in the law of the source language country as well as in the law of the target language. ${ }^{16}$ (El subrayado es agregado)

En resumen, la traducción jurídica es una traducción especializada como los otros dos campos mencionados. Quien se dedique a esta actividad, además del conocimiento de los idiomas involucrados, deberá ser poseedor de una cultura jurídica sólida lo cual no indica que deba ser necesariamente abogado, pero si lo fuera, en principio sería mucho mejor, y este activo tiene doble connotación porque debe conocer tanto su propio sistema jurídico como del país de donde proviene o se dirige el documento.

Pero, una vez que se ha entendido lo que significa la Traducción Jurídica, viene la pregunta de quién puede realizar dicha tarea de manera idónea y solvente. Evidentemente que hay muchas respuestas, pero nos quedamos con lo manifestado por Ruth Gámez y Fernando Cuñado (2015):

Existen múltiples teorías. Hay quien opina que lo principal es tener una sólida formación en el campo de la traducción, complementada con conocimiento de los sistemas legales. Otros piensan que el más capacitado para este tipo de traducción es un abogado con un buen dominio de los idiomas. Nosotros, en cambio, pensamos que no es suficiente ni una cosa ni la otra. El traductor jurídico "ideal" debe ser abogado y traductor al mismo tiempo. Lo que en el ámbito de la Unión Europea se conoce como "jurista-lingüista. (párrafo 4) $)^{17}$

Para la solución de estas carencias de especialización en traducción jurídica, las agencias de traducción nacionales deben recurrir a los especialistas en este campo con fines de consulta quienes también cobran, y ello evidentemente encarece el servicio.

Los demás se deben contentar con el uso de diccionarios de la especialidad, pero a veces tampoco ayuda mucho, como dice María Teresa Martínez (1994): "El diccionario sólo ofrece significados y esos significados no tienen sentido. Sólo con un profundo trabajo de referenciación, incluso histórica, podemos lograr un texto realmente informativo y coherente para el lector en la lengua B.” (p. 2)

\footnotetext{
${ }^{16}$ Traducción propia: «Si el traductor no es un abogado entrenado, no está necesariamente en capacidad de poder captar el sentido del texto. Por tanto, la habilidad de entender un texto depende de la preparación por la que ha pasado el traductor. El traductor ideal es aquel que es experto en el derecho del país de la lengua fuente, así como en el derecho de la lengua meta.» (Lane, 1982 p. 223).

${ }^{17} \mathrm{http}: / /$ traduccionjuridica.es/8-preguntas-sobre-la-traduccion-juridica/
} 
Por otro lado, si uno quisiera aprender a traducir dichos textos no existe literatura nacional que sirva de ayuda. Pero en verdad ni siquiera la literatura extranjera ayuda mucho en este aspecto tampoco, ya que como se ha dicho la traducción es fundamentalmente una praxis. Esta apreciación también es válida para la traducción especializada en general y a la traducción jurídica en especial. Sobre la falta de apoyo académico en materia jurídica dice el lingüista español, Roberto Mayoral (2004):

Ya se ha escrito un número significativo de libros y trabajos sobre la traducción jurídica (entre otros, podemos destacar Alcaraz, 2000a; Álvarez, 1994; Bauer-Bernet, 1983; Borja; 2000; Franzoni, 1996; Gémar, 1982, 1979; Hickey, 1996, 1993; Mayoral, 1999a y 1999b, Morris, 1995; Šarčević, 1997; Sparer y Schwab, 1980; Tomaszczyk, 1999 y Weston, 1983). Para muchos, esta aportación es insuficiente, da la impresión de que la oferta de reflexión no cubre las necesidades de explicación y predicción que experimentan profesionales, estudiosos y estudiantes. Por otro lado, un breve examen de las principales obras sobre la traducción jurídica, nos evidencia que, por lo general, tan sólo una mínima parte de todo lo escrito en ellas se centra, de forma más o menos directa, en la cuestión de cómo se hace la traducción jurídica (4 páginas de 204 en Anabel Borja, 25 páginas de 288 en Alcaraz, 3 páginas de 280 en Šarčević, 2 páginas de 329 en Álvarez). (p. 10)

En cuanto a esta pregunta de cómo se traducen los textos jurídicos, trataremos de abordarlo a continuación.

\subsection{3 ¿Cómo se hace una Traducción Jurídica?}

Por lo dicho ya se puede ir adelantando que el hecho de traducir no es simplemente "pasar" lo que dice un texto a otro sin más ni más, son elecciones que se tienen que hacer dependiendo de distintos aspectos situacionales, por ello incluso si se supiera cómo traducir (que no hay acuerdo sobre el mismo) la pregunta de cómo hacerlo es crucial.

Uno de los aspectos centrales de esta actividad es saber cómo se realiza, es decir, desde cuándo se puede decir que alguien es traductor, en cualquier campo. Creemos que esta pregunta es pertinente ya que, si existen centros de enseñanza, entonces se supone que uno puede aprender a traducir en dichos centros de enseñanza. A esta pregunta, Roberto Mayoral (2001) ya le ha dado una respuesta: 
No existe una forma única de traducir un determinado documento, ni siquiera si conseguimos ponernos totalmente de acuerdo sobre cuáles son los parámetros que imponen soluciones determinadas de traducción. Frente a estos parámetros que restringen la variedad de soluciones, existen otros que la favorecen.

En primer lugar, una buena parte de esta "variación traductora" viene impuesta por el mismo traductor. Su estilo personal, sus gustos personales, su concepción sobre la idoneidad de la traducción, su estado de ánimo y su motivación ante esa traducción en particular, las circunstancias materiales de tiempo, lugar, disponibilidad de información, su actitud ante el cliente o el contenido del texto, etc. pueden determinar, al menos en parte, la forma de traducir y las soluciones de traducción que adopta. El estudio de estos factores es probablemente el más descuidado en estos momentos debido a las concepciones reinantes sobre la traducción que piensan que las soluciones de traducción a adoptar dependen exclusivamente del texto original o, como mucho, también de la función del texto traducido y del encargo de traducción. (p. 11)

Lo dicho no hace sino confirmar que la traducción es básicamente un hacer o un saber hacer como afirma Amparo Hurtado, ello explicaría por tanto la existencia de traductores e intérpretes, muy buenos, por cierto, que sin tener noción teórica de la actividad traductora realizan trabajos por demás muy profesionales.

Por su parte, en Europa donde la traducción tiene larga data, ya se ha clasificado a los traductores por sus competencias y/o habilidades, criterio que no coincide con el criterio del legislador peruano.

Para ilustrarnos sobre ello, dicen: Muñoz Martín Valdivieso Blanco (de la Unidad Española de Traducción, Servicio Lingüístico, Consejo de la Unión Europea Bruselas, Bélgica):

\subsection{Tipología de la articulación "competencia temática-competencia lingüística.}

1) Las dos competencias se dan en una misma persona. Es el profesional que traduce, capaz de desempeñar ambas funciones con calidad de especialista. Es, naturalmente, la fórmula más difícil de alcanzar y, por tanto, constituye la excepción. (Muñoz y Valdivieso, 2006, p. 5)

Es el caso de un especialista que realiza traducciones de manera sostenible. Es decir, no solo cuenta con un bagaje en cualquier especialidad y/o profesión, sino que también está informado sobre los aspectos de la Traducción. 
Se podrá pensar que en el Perú no existen estos personajes pero sí los hay como el caso ya mencionado líneas arriba sobre la Asociación Peruana de Traductores Técnicos-científicos (APETEC) que como su nombre indica está conformada por profesionales en áreas como la Ingeniería, la Economía por citar dos ejemplos ${ }^{18}$

Su competencia se explica de acuerdo a lo que señalan los estudiosos de la traducción:

A este conocimiento lingüístico se le debe añadir la competencia enciclopédica que corresponde al conocimiento de las cosas, a la experiencia del mundo exterior, a todas las realidades que pueblan nuestro universo físico o mental. Sólo se traduce bien lo que se conoce bien y el saber extralingüístico es indispensable para aprehender y reformular un mensaje. (Delisle y Bastin, 2007, p. 244)

2) El propio especialista temático traduce el texto, aunque no sea él mismo experto en traducción. La fórmula tiene una larga tradición y numerosos defensores. "An expert in a highly technical question, if he has sufficient linguistic capacities, may be a very good extempore interpreter" (Jean Herbert, citado por Jiménez, 1998, 341). Es también a veces una fórmula insustituible. (Muñoz y Valdivieso, 2006, p. 5)

Este es el caso de ciertos especialistas en cualquier área del conocimiento que por cuestiones de trabajo tienen que traducir; pero a pesar de no estar muy informado sobre aspectos de la traducción son considerados muy competentes. Esto se da en campos como la Medicina, el Derecho, la Ingeniería entre otros.

A propósito, podemos citar un caso ilustrativo. Es el caso de la abogada inglesa Susan Wright quien era miembro del departamento de traducciones de la Corte de Justicia de la Comunidad Europea (2001) y fue invitada para realizar un trabajo sobre "El Surgimiento del Constitucionalismo entre 1776-1849” (The Rise of Constitutionalism 1776-1849). La invitación requería de la "asesoría experta de un profesional traductor de documentos jurídicos relacionado con la terminología, estilo, tiempos verbales y otros problemas".

\footnotetext{
${ }^{18}$ En materia jurídica, debemos resaltar la reciente constitución de la asociación sin fines de lucro denominada Juristas-Lingüistas Asociados (JULIA) al estilo de la figura europea.
} 
Dicha abogada ocupaba el cargo de Jurista-Lingüista en dicha institución y durante los 13 años previos a su incorporación había sido profesora de Derecho Inglés y Francés en el contexto de Derecho Comparado en su país natal, Inglaterra.

Dicha profesional no había estudiado traducción, algo común para los que desean ocupar el cargo; es más, el estudio de la traducción no es requisito para ingresar al cuerpo de Juristas-Lingüistas de la Corte de Justicia Europea. El único requerimiento es que uno tenga habilidad para traducir. En ese sentido, la abogada Wright pensó que sí estaba en posibilidad de encargarse del trabajo requerido y aceptó la invitación.

El presente caso es un ejemplo que pone de relieve que lo que prima son las capacidades idiomáticas y habilidades para poder traducir aunque no hubiese recibido capacitación formal para ello. Solo una persona con dichas cualidades podría decidir asuntos tales como el estilo de los textos que iban ser traducidos, así como el tipo de inglés (americano o británico) entre otras consideraciones.

3) El texto lo traduce un traductor especializado, que tiene una competencia referencial considerable en un número reducido de temas. (Muñoz y Valdivieso, 2006, p. 5)

Es el caso de los traductores egresados de universidades o institutos que por su experiencia y ciertos estudios complementarios han comenzado a especializarse en ciertas áreas ya sea por haber llevado algunos cursos o por la asistencia a seminarios $\mathrm{u}$ otros eventos lo que les ha permitido hacerse de un bagaje respetable aunque no comparado con el verdadero especialista. En nuestro medio vendría a ser el caso de los Traductores Públicos Juramentados (TPJ) a quienes la ley no les exige otro activo adicional además del idiomático, pero como está vinculado al área jurídica, han logrado o están logrando tener un cierto dominio del tema legal en sus traducciones por su larga experiencia.

4) El texto lo traduce un traductor generalista, cuyas competencias referenciales, si bien no pueden ser profundas, sí abarcan, en cambio, una mayor variedad temática. Obviamente, cuanto menor sea la especialización temática del traductor, más necesaria será la aportación del experto, según las fórmulas siguientes: 
a) El especialista transmite al traductor la información a través de "mediadores materiales": glosarios, bancos de datos, textos paralelos, documentación diversa, etc. La comunicación es limitada, ya que es unidireccional.

b) El traductor consulta al especialista directamente por diversas vías de comunicación: cauces institucionales, foros de debate, etc.

c) Especialista y traductor trabajan de modo convergente. El texto especializado traducido es el resultado de una labor de equipo. Es la fórmula que aúna con más garantías las dos competencias. (Muñoz y Valdivieso, 2006, p. 5)

Este es el caso de los traductores que egresan de institutos o universidades en el Perú quienes -según esta clasificación-son considerados traductores generalistas y que como reconocimiento de su carencia se tienen que vincular y/o tienen que consultar con otros especialistas para poder sacar adelante sus traducciones.

Tal como veremos más adelante, los distintos Reglamentos que han sido promulgados y regulan la Ley de Contrataciones con el Estado han optado por los traductores que ocupan los niveles 3 y 4 de la presente clasificación lo que nos revela su desconocimiento sobre el tema de la traducción.

\subsection{Traducción Jurídica y Derecho Comparado}

Desde hace mucho tiempo hemos escuchado y leído comentar a especialistas como Ada Franzoni, Jean Kerby, Anabel Borja, Miguel Duro -entre otros- que en el caso de la Traducción Jurídica siempre es necesario efectuar una labor de Derecho Comparado, algo que compartimos. Además sobre la combinación lenguaje jurídico y derecho comparado también hay consenso como dice Morán (2002):

La primera gran dificultad que entraña el Derecho Comparado no es de índole puramente jurídica sino también lingüística y cultural, pues aun conociendo el idioma y perteneciendo a un entorno cultural próximo, las dificultades en la comprensión de terminología, conceptos e instituciones jurídicas suponen una auténtica barrera inicial para afrontar el estudio y conocimiento de un sistema jurídico ajeno. (p. 5)

Apelando a nuestra experiencia y siguiendo al jurista canadiense Jean Kerby en este punto, podemos afirmar que los documentos que traducimos con más frecuencia provienen del idioma inglés el mismo que pertenece al sistema del "Common Law", 
sistema que ha tenido un desarrollo distinto al nuestro. El mismo término de Common Law es ya un problema ${ }^{19}$ y al traducir algunos vocablos nos vamos a encontrar que no tiene un equivalente exacto en nuestro sistema quedando desnaturalizado el concepto jurídico al tratar de darle una versión en español. En consecuencia, podemos adoptar una primera posición que es la dejar sin traducción por ser "intraducible" o en su defecto proceder a explicarlo (lo cual quiere decir que ya no es una traducción); en cualquiera de los casos estamos reconociendo que el traductor previamente se ha informado acerca de las implicancias de dicha figura en el sistema extranjero.

\subsubsection{Problemas lingüísticos}

Aunque no divorciados de los problemas jurídicos, los problemas lingüísticos más comunes que se presentan en la traducción jurídica son los siguientes:

a) La presencia de "faux amis" 20 es de una frecuencia sorprendente y esto como muchas otras instituciones del Common Law tienen una explicación histórica. Nos remitimos a la época de la conquista normanda, época en la que los hombres de la nobleza y los hombres de derecho hablaban francés en los tribunales. Así mismo las primeras recopilaciones jurisprudenciales están redactadas en idioma francés, pero en un francés de dicha época, hablado por los normandos entre los siglos XI y XVI distinto del francés hablado en Francia en el mismo periodo. Tenemos algunos ejemplos como agency: mandato; agent: mandatario; assignment: cesión de derechos: copy: ejemplar; evidence: prueba. El vocablo evidencia en español es sinónimo de obvio, en inglés (jurídico) es obviousness, también está jurisprudence: Ciencia del Derecho o Teoría del Derecho y no jurisprudencia que en todo caso sería CASE LAW, es decir la fuente del derecho proveniente de los fallos de los tribunales de mayor jerarquía.

\footnotetext{
${ }^{19}$ Incluso H.H. A. Cooper ha encontrado al menos 4 significados distintos a este término. En este caso nos referiremos a él como el sistema legal propio de los países anglosajones. Cooper, H.H.A. Diez Ensayos sobre el Common Law, Edit. Universo, Lima, 1967, p. 5.

20 Los falsos amigos son palabras morfológicamente iguales en dos idiomas entre las que no existe correspondencia semántica. Definición de Elsa T. de Pucciarelli entre otras.
} 
b) En el aspecto estilístico se puede notar que el inglés jurídico tiene también mucho de francés, para algunos es otro idioma prácticamente distinto del inglés estándar. En el inglés jurídico se muestran frases compuestas por vocablos en ingles seguidos por otros en francés. Ejemplo, last will and testament, of sound mind and memory, fit and proper etc.

c) También se presentan expresiones en latín, pero no del latín que proviene del derecho romano como en nuestro sistema, e.g. STARE DECISIS, RES IPSA LOQUITUR, etc.

En suma, para realizar traducciones jurídicas (sobre todo en inglés) no solamente se requiere el conocimiento de los dos idiomas sino también se debe conocer el sistema jurídico del país proveniente, por ello es que los traductores en general de otros países visitan periódicamente las naciones de donde provienen los textos que ellos traducen con el propósito de asimilar en algo su cultura, esto no es menos cierto en el caso de la traducción jurídica; más aún según sentencia Jean Kerby:

Comme M. Jourdain faisait de la prose sans le savoir, le traducteur juridique se trouve à faire régulièrement du droit comparé. Il ne suffit pas de connaître les deux langues, il faut également une initiation aux deux systèmes de droit qui coexistent au Canada. ${ }^{21}$ (Kerby, 1982, p. 10)

Para concluir diremos que nos parece imperativo que nuestros juristas no se limiten al estudio de la legislación nacional sino que extiendan con más frecuencia sus inquietudes hacia otras realidades para así mejorar nuestro sistema, a decir de Ayasta (1991):

Entre todas las ciencias, sólo la del Derecho ha creído, falsamente, que podía ser puramente nacional. Mientras que los teólogos, los historiadores, los médicos, los químicos, los astrónomos y todos los demás hombres de ciencia han tratado de acoger los progresos de su disciplina en el extranjero; los juristas se han limitado al estudio de su Derecho Nacional. (p. 40)

La única diferencia, en no pocos casos, entre los connotados juristas nacionales y de una legión anónima puede ser solamente que los primeros tienen acceso al derecho extranjero debido a su conocimiento de otros idiomas, mientras que para los segundos la alternativa

${ }^{21}$ Traducción propia: «Al igual que Jourdain que hacía prosa sin saberlo, el traductor jurídico se encuentra normalmente haciendo derecho comparado. No es suficiente conocer las dos lenguas, hace falta también iniciarse en los dos sistemas jurídicos que coexisten en Canadá. » 
sería la traducción hecha en el Perú, pues el concepto de división del trabajo tampoco es ajeno a este campo.

Para complementar con esta parte y tal como dijimos, el lenguaje jurídico tiene ciertas características que no tiene otro tipo de lenguaje especializado. No es nuestra intención agotar el tema pero sí dejar en claro que este tipo de lenguaje (jurídico) tiene ciertas características muy particulares, tal como menciona Díaz Muñoz (2009):

De lo anterior se deduce, que el lenguaje jurídico es un lenguaje complejo y difícil, con escasez de sinónimos, un lenguaje profesional y especializado solo comprensible para los profesionales del Derecho. (p. 87).

Además, en algunos círculos ya se empieza a hablar de una nueva especialidad: la jurilingüística.

\subsubsection{Problemas jurídicos}

Sin esta documentación comparativa previa, no se podrá intentar la traducción de muchos textos en forma fidedigna. Veamos algunos ejemplos: en el Common Law existe un sistema jurídico paralelo llamado Equity que en un inicio estuvo a cargo del Canciller nombrado por el Rey para administrar justicia. Sin embargo, en nuestro sistema no existe nada parecido; de los especialistas estudiados, todos señalan que Equity no se debe traducir. Del mismo modo tenemos otros términos como TORT, TRUST, entre muchos otros.

Otro ejemplo ilustrativo se halla en el campo del derecho de sucesiones; resumiendo el tema podemos decir que en nuestra realidad el momento en que la herencia pasa a los herederos es al fallecimiento del de cujus, dichos herederos tienen en nuestro sistema la posibilidad de aceptarla, rechazarla o de aceptarla con beneficio de inventario. Tales posibilidades no son conocidas en el Common Law. En efecto en dicho sistema los bienes de la sucesión (ESTATE) pasan por las manos de un representante que si es nombrado por testamento se llama EXECUTOR y si es nombrado por un tribunal se llama ADMINISTRATOR, es finalmente este personaje quien se encarga de pagar las deudas de la sucesión y si resulta un saldo positivo, éste pasa a manos de los herederos. 
Por ello, algunos creen que lo mejor manera de traducir textos jurídicos para salir del problema es la literal, es decir pegado al texto de origen. Pero esta práctica tampoco es fiable del todo, como señala nuevamente el español Mayoral (2001):

$\mathrm{Si}$, en general, para los participantes en una traducción jurídica (y otras) la forma de traducir más conveniente es la literal (sea cual sea su concepto de literalidad), éste no es el caso para unos elementos en particular de los textos jurídicos: los conceptos jurídicos especializados. Resulta tan patente la inequivalencia de conceptos jurídicos entre algunos sistemas, como el angloamericano y el español, que la primera solución de traducción que asalta el cerebro del traductor no es la "traducción literal" sino la traducción por el equivalente funcional, es decir, por aquel concepto o institución jurídica que cumple el mismo papel en la cultura del texto traducido. Este concepto de equivalente funcional como solución por defecto tiene un origen comparativista, procedente de la comparación de sistemas jurídicos y es de uso corriente en obras lexicográficas. (p. 10)

Eso estaría bien si hubiera equivalencias entre los sistemas, pero como en el caso de la realidad peruana en la que muchos textos traducidos vienen de un sistema distinto al nuestro, la técnica del equivalente funcional parece tampoco tener el éxito asegurado.

En ese sentido se pronuncia la abogada-traductora argentina María Teresa Martínez, graduada de la Universidad de Buenos Aires, Argentina, quien fue por muchos años intérprete de Corte del Tribunal Superior del Condado de Maricopa en el Estado de Arizona, EE. UU. Ella formó parte, además, del programa de traducción de la Universidad Estatal de Arizona dictando los cursos de Teoría y Práctica de la traducción y traducción de textos Legales en calidad de Profesora Invitada. Dice la abogada en una explicación sobre la traducción de un documento legal:

La siguiente exposición intentará demostrar que dentro de un marco de referencia que, en el caso del inglés, es reflejo y fuente de una cultura jurídica basada en la tradición anglosajona del Common Law y, en el caso del castellano, reflejo y fuente a su vez del sistema jurídico basado en la tradición francesa del Derecho Civil, la traducción de textos jurídicos del inglés al castellano y viceversa es una verdadera utopía, ya que la realidad de los valores ideológicos que gobiernan cada uno de los dos sistemas es exclusivo de cada uno de ellos. (p. 1) 
Creemos que ha sido demostrado con suficientes argumentos y validado por especialistas (extranjeros) consagrados que la traducción jurídica y el Derecho Comparado están estrechamente vinculados. Por tanto, el traductor, el verdadero traductor debe cumplir los 3 requisitos que sostiene la "doctrina" los que no han cambiado: i) conocimiento de su propia lengua, ii) conocimiento de la lengua extranjera y iii) conocimiento del campo que intenta traducir. 


\section{CAPITULO III: LAS TRADUCCIONES Y EL OSCE}

\subsection{Uso actual de las traducciones en el mercado}

A partir de la década de los 90, se inicia una gran transformación en la demanda de las traducciones en el mercado. Esto coincide con la apertura del Perú a la comunidad internacional.

Por tanto, los años 90 marcan una clara diferencia con lo que sucedía antes en relación con la demanda de servicios de traducción e interpretación. Antes de los 90 era una demanda modesta pero sostenida, pero a partir de la fecha mencionada, el incremento de la demanda de estos servicios aumenta de manera considerable y podemos afirmar que ha seguido en aumento incluso en idiomas no tan tradicionales.

Además del aumento cuantitativo, la demanda de los servicios de traducción presenta una característica cualitativa que describimos a continuación:

En primer lugar, en cuanto al tipo de documentos que necesitan ser traducidos, éstos ya no son los que tradicionalmente se traducían y que eran principalmente la correspondencia epistolar y todos aquellos documentos que requerían de traducción por motivos de estudios o trabajo en el extranjero, o la conocida correspondencia comercial. Estamos haciendo referencia a las partidas del estado civil, o sea de nacimiento, matrimonio, defunción, constancia de trabajo y certificados de estudios entre otros.

A partir del momento mencionado (años 90), los documentos que necesitan ser traducidos son de una gran variedad, como contratos, informes financieros, artículos especializados, consultas, revistas, reportes, balances, escrituras de constitución, sentencias judiciales, documentos de la administración pública que deben ser tramitados ante diferentes entidades del gobierno, documentos notariales, entre otros. Igualmente sucede en otros campos distintos del jurídico como son especialmente el caso de la traducción técnico-científica. El campo literario prácticamente ha permanecido inactivo.

Sin embargo, como ya dijimos en la cita 43, un trabajo realizado por la agencia de traducción Lexitrans, una de las más antiguas e importantes del país asegura que la traducción jurídica ocupa más del 60\% de la demanda. Más recientemente, la entonces 
Decana del CTP menciona en una entrevista en el diario El Comercio que el $80 \%$ de los documentos relacionados con los tratados de libre comercio no están en español.

Dice literalmente la ex decana:

El año pasado hice una tabla, un análisis de las exportaciones e importaciones del país en el 2010. Me di con la sorpresa de que el $80 \%$ de exportaciones e importaciones es comercializado con países que no son de nuestra lengua. (Monteagudo, 2012, p. A24).

Por otro lado, la traducción no es solo directa, sino también inversa; es decir de documentos que son enviados al extranjero lo que permite concluir que la actividad traductora tiene como mercado al mundo.

Otro aspecto que se debe destacar como ya se dijo, es que la mayor cantidad de documentos son textos especializados, tal como mencionamos en el punto 1 sobre traducción especializada del Capítulo II.

\subsubsection{Sector Privado}

En el caso del sector privado, se da una demanda que exige del traductor una solvencia que no tiene antecedentes y que muy pocos están en condiciones de ofrecer. Igualmente el volumen de trabajo en el campo de la interpretación se ha multiplicado de manera exponencial.

Antes de dicha época, los usuarios de interpretación eran muy pocos, pero hoy día se ha generalizado a todo nivel. Se requieren de intérpretes, para reuniones de negocios en las que intervienen personas que hablan otros idiomas. Para visitantes o expositores en diversos tipos de eventos, no solo comerciales sino educativos, académicos, científicos y hasta los grandes congresos en las diferentes especialidades como medicina, derecho, comercio internacional pasando por los eventos religiosos etc., de esto nos dan cuenta los medios de comunicación con frecuencia.

Como consecuencia de lo mencionado, el traductor tenía que ser a partir de dichos momentos un traductor especializado. Sin embargo, la oferta no siguió a la demanda; solo de manera reciente hace aproximadamente unos 5 años se ha empezado a hablar de traducciones especializadas y de traductores especializados. En ese sentido, recién hace 
dos años (28 y 29 de Setiembre de 2014) se llevó a cabo en Lima el I Congreso Internacional de Traducción Especializada.

\subsubsection{Sector Público}

A diferencia de algunos años, en la actualidad el uso de traducciones en el sector público está muy difundido. La cantidad de documentos públicos que llegan al país propició que se apruebe el Convenio de la Haya en relación a la Apostilla recién el año 2010 y entró en vigencia el 30 de setiembre del mismo año. ${ }^{22}$

Como en el caso del APEC (Asian Pacific Economic Community) y muchos otros congresos internacionales de diversa naturaleza, se requiere también servicios de traducción para los juicios en los que intervienen acusados, testigos de otras nacionalidades, matrimonios, accidentes, procesos de extradición, requisitorias internacionales, exequátur entre otros.

En el sector público, las traducciones de corte jurídico, se encuentran en diferentes ámbitos, Nos referiremos especialmente las que se encuentran en los diferentes poderes del Estado. Tenemos referencias de que se hacen traducciones en el Congreso de la Republica, Ministerio Público, Contraloría General de la República Superintendencia de Administración Tributaria (SUNAT), Superintendencia de los Registros Públicos (SUNARP), por mencionar algunas de las instituciones más representativas.

También se hacen para el Poder Judicial, tradicionalmente para los trámites de adopción; pero tenemos noticias de que se hacen también en procesos penales debido a que muchos procesados son extranjeros, lo mismo ocurre en arbitrajes y otros procesos judiciales.

Aquí se presenta una contradicción con el cargo de TPJ, el mismo que fue creado "para uso y servicio de particulares" como dice su ley, pues ha sido el sector público el que ha requerido también de sus servicios. ${ }^{23}$

Por su parte, los administrados se han estado acogiendo de manera supletoria al Art. 41.1.2. de la Ley $\mathrm{N}^{\circ} 27444$ que solo exige traducciones simples ante requerimiento

\footnotetext{
${ }^{22}$ Dicho Convenio se aprobó por Resolución Legislativa $\mathrm{N}^{\circ} 29445$ y posteriormente se ratificó por Decreto Supremo $\mathrm{N}^{\circ}$ 086-2009-RE. Se publicó en el diario oficial El Peruano el 15 de octubre del mismo año 2010. ${ }^{23}$ Decreto Ley $\mathbf{N}^{\circ}$ 18093. Art. $1^{\circ}$.- Créase el cargo de Traductor Público juramentado para la traducción de documentos para uso y servicio de particulares que será ejercido por profesionales libres.
} 
de algunas entidades administrativas (por ejemplo, la SUNAT, por mencionar una de las instituciones que ha seguido esta ley); pero otras dependencias han expedido sus propias normas (decretos supremos, resoluciones supremas principalmente) como es el caso de la Superintendencia de Migraciones, requiriendo traducciones "oficiales" o "certificadas".

\subsection{La regulación de las traducciones ante el Osce}

Igualmente se requiere de estos servicios para los procedimientos de selección de contrataciones del Estado regulado por el Organismo Supervisor de Contrataciones del Estado (OSCE). En efecto, tenemos documentos que se encuentran en otros idiomas, que los postores necesitan traducir para cumplir con los requisitos exigidos en cada caso por la respectiva Entidad, si desean brindar sus productos o servicios al Estado, los mismos que son muy buscados debido a la dimensión del servicio.

Dichos documentos son de una gran variedad, desde los documentos de sus representantes, que en caso sean extranjeros se encuentran en otros idiomas, certificados de calidad, certificados de origen, constancias de diverso tipo, descripciones de los manuales, testimonios, propaganda, patentes, cartas, contratos, poderes, constitución de empresas, informes financieros, fallos judiciales, estados de cuenta, entre otros; que de una u otra manera favorecen al postor porque ayuda a incrementar su prestigio, imagen o dan cuenta del volumen de sus ventas, entre otros aspectos empresariales, que pueden ser exigidos como requisitos para el concurso respectivo.

Por lo tanto, al postor no le queda más remedio que recurrir a la traducción de sus documentos que provienen en otro idioma (con la excepción que menciona el art. $62^{\circ}$ de dicho reglamento y de los posteriores que le siguieron); es decir, que la información técnica puede quedar en el idioma original.

Dichos documentos, como dijimos antes, son de una gran variedad, pero tienen algo en común, la gran mayoría por no decir todos, son documentos altamente técnicos, es decir contienen una terminología especializada, esto debido a la especialidad de los textos y de las actividades que requiere el Estado para el cumplimiento de las tareas que le son propias. Estas van desde adquisición de materiales de construcción, artefactos de distinta naturaleza, productos químicos, repuestos, herramientas de todo tipo, patentes, aparatos sofisticados, y una larga lista de todos ellos hasta la actividad de la asesoría, 
material médico, aparatos de diverso tipo llegando incluso las referidas a información administrativa, legal y tributaria. Todos estos documentos no solo son complejos en su redacción, sino son altamente técnicos, como señalamos ya que recogen una terminología propia de cada área del conocimiento, que como se comprenderá, son incontables. Además recordemos que la tecnología de punta proviene del exterior en gran medida.

Ante este problema y debido a que el Perú ha escogido principalmente el español como idioma oficial (Constitución Art. 48), el Ministerio de Economía y Finanzas ha reglamentado el uso de dichas traducciones para los fines comentados.

Para ello ha emitido a la fecha, tres decretos supremos que regulan la Ley de Contrataciones del Estado (Decreto Legislativo $\mathrm{N}^{\circ}$ 1017) y un cuarto decreto supremo de la nueva Ley $\mathrm{N}^{\circ} 30225$ que regulan de maneras distintas esta actividad.

\subsubsection{Decreto Supremo $\mathrm{N}^{\circ}$ 184-2008-EF}

El Decreto Supremo N ${ }^{\circ}$ 184-2008-EF, es el primero sobre el tema que se publicó el 31 de Enero de 2009, el mismo que en su art. $62^{\circ}$ dice lo siguiente:

\section{Artículo 62.- Presentación de documentos}

Todos los documentos que contengan información referida a los requisitos para la admisión de propuestas y factores de evaluación se presentarán en idioma castellano o, en su defecto, acompañados de traducción efectuada por traductor público juramentado, salvo el caso de la información técnica complementaria contenida en folletos, instructivos, catálogos o similares, que podrá ser presentada en el idioma original. El postor será responsable de la exactitud y veracidad de dichos documentos. La omisión de la presentación del documento o su traducción no es subsanable.

Cuando se exija la presentación de documentos que sean emitidos por autoridad pública en el extranjero, el postor podrá presentar copia simple de los mismos sin perjuicio de su ulterior presentación, la cual necesariamente deberá ser previa a la firma del contrato. Dichos documentos deberán estar debidamente legalizados por el Consulado respectivo y por el Ministerio de Relaciones Exteriores, en caso sea favorecido con la Buena Pro. (El subrayado es agregado)

En el caso que nos ocupa, podemos decir que en este Reglamento se apela al uso de las traducciones efectuadas por Traductor Público Juramentado de manera exclusiva. 
A pesar que el TPJ puede expedir tanto traducciones oficiales como no oficiales, el Reglamento no hace mención alguna sobre este aspecto, por lo que debemos asumir que puede aceptar los dos tipos de traducciones: las oficiales y las no oficiales. Pues como reza dicho artículo basta que sea efectuada por un TPJ, para que el OSCE le dé el visto bueno.

Sin embargo, dicha interpretación no es correcta según nuestra óptica, pues si así fuera, entonces el OSCE estaría discriminando a otros traductores que expiden también traducciones no oficiales. Además, ha rechazado ya en varias oportunidades la presentación de documentos traducidos por TPJ sin las legalizaciones requeridas. Por tanto, a nuestro modo de ver las cosas se está apelando al uso de traducciones oficiales de manera exclusiva sin mayor razón, tal como adelantáramos.

En otras palabras, el Ministerio de Economía y Finanzas, emisor de la norma, consideró que los TPJ solo deben expedir traducciones oficiales, las mismas que merecen ser considerados plausibles, pues supuestamente para ello se ha creado dicha función. Igualmente se parte de la convicción de que el proceso de traducir no conlleva mayor dificultad, tanto en su ejecución como en su tramitación. Sin embargo, eso no es cierto conforme estamos exponiendo en este trabajo.

\subsubsection{Problemas.}

En este caso y de manera casi automática, el Ministerio de Economía y Finanzas (MEF) ha apelado a los servicios de los TPJ, ya analizado en el primer capítulo de manera exclusiva, sin darse cuenta de que dichos profesionales solo cuentan con traductores para 9 idiomas, ${ }^{24}$ número insuficiente si consideramos que solamente la Unión Europea tiene 24 idiomas oficiales y que potencialmente podría haber un documento en alguno de esos idiomas. Dichos idiomas son: alemán, búlgaro, checo, croata, danés, eslovaco, esloveno, español, estonio, finés, francés, griego, húngaro, inglés, irlandés, italiano, letón, lituano, maltés, neerlandés, polaco, portugués, rumano y sueco.

\footnotetext{
24 Tomado del Listado de Traductores Públicos Juramentados del Ministerio de Relaciones Exteriores. Recuperado de www.consulado.pe/Paginas/Traductores.aspx
} 
Los idiomas que cuentan con TPJ, son: alemán, chino, francés, inglés, italiano, japonés, polaco, portugués y ruso. Por tanto, el primer problema es el número insuficiente de "traductores oficiales" para una eventual demanda que podría presentarse en cualquier idioma de los 7,012 que se consideran existen en el mundo (Ver cita 6).

El segundo problema es lo engorroso de su tramitación. Ya hemos observado en el primer capítulo todos los pasos por los que tiene que pasar una traducción oficial y ello colisiona con la celeridad de las actividades comerciales en un mundo competitivo como el actual. Por ejemplo, en Chile, el abogado José Miguel Ried Undurraga se ha pronunciado por la eliminación de este tipo de traducciones, a las que ha denominado “anacrónicas”. Nosotros secundamos dicha afirmación. Igualmente, en la Unión Europea existe ya una tendencia a la eliminación de la traducción oficial. Nosotros también estamos de acuerdo con esta posición, el proyecto al respecto fue presentado por Viviane Reding con el propósito de simplificar el tráfico documentario en dicho continente cuyo borrador citamos:

\section{Artículo 6}

\section{Traducciones no juradas}

1. Las autoridades aceptarán las traducciones no juradas de los documentos públicos expedidos por las autoridades de otros Estados miembros.

2. Cuando una autoridad albergue dudas razonables sobre la corrección o la calidad de la traducción de un documento público que se le presente en un caso particular, podrá solicitar una traducción jurada de ese documento. En ese caso, la autoridad aceptará las traducciones juradas realizadas en otros Estados miembros. (Reding, 2013)

Un tercer problema es la falta de especialización de dichos traductores que, como mencionamos anteriormente, ocupan el tercer lugar según detalláramos en el respectivo estudio del capítulo sobre traducción especializada. ${ }^{25}$

Evidentemente habrá excepciones que confirman la regla, pero la crítica es al Ministerio de Relaciones Exteriores que no exige ninguna especialización a los postulantes al cargo de TPJ a sabiendas de que dicho traductor tiene claramente un perfil jurídico.

${ }^{25}$ Nos referimos a los traductores generalistas que cuentan con alguna no muy profunda especialización. 
Finalmente, el cuarto problema es el elevado costo del servicio. Este precio se eleva si se requieren traducciones con carácter de urgencia. Esta característica de urgencia es común en el mundo empresarial y jurídico; por ello es comprensible que en no pocos casos, la redacción de dichos documentos no sea ideal, pues se hacen "contra el reloj".

\subsubsection{Consecuencias.}

En cuanto a la falta de TPJ, la consecuencia es que en algunos casos, los postores no han podido presentar la documentación que estaba en otro idioma distinto del español y por ello se han tenido que abstener perdiendo algunos puntos en la competencia. No se ha recurrido a otros traductores porque la exigencia era que tenían que ser traducciones oficiales.

Los que han apelado al uso de traducciones simples, es decir, hechas por alguien que no es TPJ, han perdido la buena pro y han sido inhabilitados. En otros casos, se ha tenido que otorgar la buena pro al segundo que, como se puede comprender no es tan competente como el primero, y en otros casos se ha declarado desierta la licitación o concurso.

En ese sentido, tenemos noticias que la Universidad Cayetano Heredia presentó un diploma de uno de sus investigadores expedido en idioma Latín por la Universidad Georgetown (EE. UU.), la cual ante la ausencia de traductor oficial en latín perdió la buena pro (aunque es bueno mencionar que ganó en una segunda convocatoria) pero fue inhabilitada. ${ }^{26}$

En segundo lugar, en cuanto a lo engorroso del trámite, esto ha producido lo mismo, es decir, los postores han tenido que abstenerse de presentar dichas traducciones por la demora del servicio.

En tercer lugar, en cuanto a la onerosidad del servicio, es corriente tener que pagar en promedio S/. 100 nuevos soles o más por una página de 180 palabras y a veces mucho menos como en el caso de documentos que tienen pocos párrafos, incluso líneas. Otras traducciones que no tienen el halo de oficialidad, cuestan $30 \%$ y hasta $40 \%$ menos.

En cuarto lugar, debido a la falta de especialización del TPJ es posible que se hayan producido algunos yerros, esto no se puede asegurar porque no se ha hecho una

${ }^{26}$ Recuperado de https://www.youtube.com/watch?v=omJkhUeezSc 
revisión de los documentos. Para evitar este problema, es bastante frecuente que los traductores (no solamente los TPJ) tengan que recurrir a otros especialistas para hacerles consultas y/o contratar a revisores de textos, aumentando así aún más los costos del servicio y el plazo de entrega de las traducciones.

En quinto lugar, en el caso de los documentos privados traducidos sin legalizaciones, no han sido aceptados, a pesar de haber sido hechos por los mismos TPJ anulándose el proceso en caso lo hayan hecho.

Finalmente, y como es natural, el inicio de la ejecución del contrato se ha diferido y/o suspendido, quedando pendiente la entrega de bienes a las entidades que la necesitan o en otros casos la licitación ha quedado desierta. Veamos algunos casos sobre este tema:

\section{- Caso 1:}

Este caso trata de la Licitación Pública N 002-2009-ESSALUD/GLC. En el presente procedimiento, el postor ganador fue la empresa CONSORCIO MIRALLES \& BURGA S.A.C. - IMPORTADORA MEDICAL S.A., y quedó en segundo lugar, la IMPORTADORA DROGUERÍA CASA SALAR S.A.C. - IDROCSA S.A.C.

El 28 de diciembre de 2009, IDROCSA S.A. en la ampliación de su impugnación (la primera fue por un error tipográfico) alega que el ganador de la buena pro presentó el Certificado de la Comunidad Europea Directiva No 93/94 EEC No DD 600176890001 acompañado de una traducción simple, motivo por el cual solicita la descalificación del ganador.

Debe tenerse en cuenta que el presente procedimiento de selección se llevó a cabo estando vigente la Ley de Contrataciones del Estado, aprobada por Decreto Legislativo No 1017, y su Reglamento, aprobado por Decreto Supremo No 184-2008-2008-EF; por lo que tales disposiciones legales resultan aplicables.

El Adjudicatario, por su parte, presentó a fojas 95 y 96 de su propuesta técnica, el Certificado de la Comunidad Europea Directiva No 93/94 EEC No DD 600176890001 a modo de Certificado de Buenas Prácticas de Manufactura del Fabricante (CBPM), el mismo que fue acompañado de traducción simple.

En efecto, al efectuar la revisión y análisis de la propuesta del Adjudicatario se advierte que las traducciones consignan la leyenda "Traducción Simple"; asimismo, en 
dicho documento se advierte que no ha sido elaborado por traductor público juramentado, tal como señala la norma citada y las Bases integradas en los fundamentos pertinentes.

Por su lado, el impugnante sí presentó traducciones oficiales, las mismas que fueron efectuadas por doña Celia María Briones Astete, Traductora Pública Juramentada $\mathrm{N}^{\mathrm{o}}$ 8, para los documentos presentados como Certificado de Buenas Prácticas de Manufactura. Asimismo, la traducción oficial se realizó en documentos sellados por el Ministerio de Relaciones Exteriores y legalizados por el consulado peruano en China.

La Sala que conoció el caso resolvió declarando que su decisión se ciñó a reiterada jurisprudencia sobre el tema (Resoluciones No 2537/2009.TC-S2, No 2593/2009.TC-S2 y $\mathrm{N}^{\mathrm{o}}$ 2592/2009.TC-S2, entre otras) y, en consecuencia, declaró fundada la impugnación. En ese sentido falló descalificando al CONSORCIO MIRALLES \& BURGA S.A.C. IMPORTADORA MEDICAL S.A., por los argumentos expuestos en la parte considerativa de la Resolución (Resolución N 044-2010-TC-S2). En segundo lugar, decidió otorgar la buena pro del ítem No 134 de la Licitación Pública No 002-2009ESSALUD/GCL al impugnante, es decir a IDROCSA S.A.C.

\section{- Caso 2:}

Este caso tiene al Hospital NACIONAL Docente Madre Niño como la Entidad que convoca la Licitación Pública 02-2009/HONADOMANI-SB (22 de julio de 2009), para la adquisición de material médico y hospitalario, por un valor referencial que asciende a la suma de S/. 3417282.76 (Tres millones cuatrocientos diecisiete mil doscientos ochenta y dos nuevos soles con setenta y seis céntimos).

El 05 de octubre de 2009 se publicaron los resultados de la evaluación técnica y económica tal como consta en el SEACE. La buena pro del referido ítem fue adjudicada a IMPORTACIONES ALPES PERU SAC.

El 15 de octubre de 2009, Dentilab del Perú SRL, es decir el impugnante, presentó un recurso de apelación contra el otorgamiento de la buena pro del ítem $\mathrm{n}^{\mathrm{o}} 48$. Éste fue subsanado el día 19 del mismo mes y año. Su recurso de apelación se interpuso bajo los siguientes argumentos: 
a.- Que el postor ganador no cumplió con uno de los requisitos de admisibilidad de la propuesta, que es presentar los documentos que no estén en castellano, acompañados de su traducción por traductor público colegiado.

b.- Que, además, el "Certificate of Free Sale" presentado por el ganador no cumple con certificar el producto que se solicita en el ítem $n^{\circ} 48$.

Debe tenerse en cuenta que el presente proceso de selección se llevó a cabo estando vigente la Ley de Contrataciones del Estado, aprobada por Decreto Legislativo No 1017 - Ley derogada en la actualidad por la Ley $N^{\circ} 30225-$, y su Reglamento, aprobado por Decreto Supremo No 184-2008-2008-EF - el Reglamento- por lo que tales disposiciones se aplican al caso.

En el caso que nos ocupa, las Bases Integradas, en el literal 1) del numeral 2.9, solicitaron que los postores presentaran en sus propuestas de manera obligatoria copia simple del certificado de Buenas Prácticas de Manufactura (BPM). En el caso de droguerías debía presentarse copia simple del certificado de BPM del país de origen emitido por la autoridad sanitaria competente con su respectiva traducción. En caso que el país de origen no otorgue dicha certificación, se aceptaría un documento vigente emitido por autoridad sanitaria competente que acredite el cumplimiento de las BPM (Certificado de Libre Comercialización o Certificados de Libre Venta).

Sobre el particular, debe señalarse que de acuerdo con lo establecido en el artículo 62 del Reglamento, todos los documentos que contengan información referida a los requisitos para la admisión de propuestas y factores de evaluación se presentarán en idioma castellano o, en su defecto, acompañados de traducción efectuada por traductor público juramentado, exceptuándose la información técnica complementaria contenida en folletos, instructivos, catálogos o similares, que podrán ser presentados en el idioma original. Asimismo, en la citada norma se menciona que la omisión de la presentación del documento o su traducción con las condiciones señaladas, no resulta ser subsanable. (el subrayado es agregado).

Es el caso que el Adjudicatario incluyó en su oferta el documento denominado "Certificate of Free Sale" (a fojas 134 de los antecedentes administrativos y folio 71 de la propuesta técnica) emitido por la Administración de Drogas y Alimentos de Zibo a favor de la empresa fabricante Shandong Zibo Shanchuan Medical Instrument Co. Ltd. 
Dicho documento fue presentado por dicho postor como documento alternativo al certificado de Buenas Prácticas de Manufactura.

Adicionalmente, incluyó una hoja con la traducción de dicho certificado, (a fojas 135 de los antecedentes administrativos y folio 72 de la propuesta técnica) siendo que no se evidencia en dicha traducción que la misma haya sido elaborada por traductor público juramentado, tal como señala la norma citada en el fundamento precedente.

Por otro lado, el Adjudicatario incluyó en su oferta el documento denominado “Authorization of distributor" (a fojas 132 de los antecedentes administrativos y folio 69 de la propuesta) emitido por Shandong Zibo Shanchuan Medical Instrument Co. Ltd. a favor de la empresa Importaciones Alpes Perú SAC.

Adicionalmente, incluyó una hoja con la traducción de dicho documento, (a fojas 170 de los antecedentes administrativos y folio 70 de la propuesta técnica) siendo que tampoco se evidenciaba en dicha traducción que la misma haya sido elaborada por traductor público juramentado, tal como señala el artículo 62 citado.

Por las consideraciones expuestas, en aplicación de lo dispuesto en el artículo 119 del Reglamento, correspondió declarar fundado este extremo del recurso de apelación interpuesto por el Impugnante contra el otorgamiento de la buena por del ítem $\mathrm{N}^{\circ} 48$, el cual se revocó. De acuerdo a esto el cuadro comparativo quedaría como sigue:

Tabla 3.1.

Resultado de la licitación

\begin{tabular}{|l|c|c|c|c|}
\hline \multicolumn{1}{|c|}{ Postor } & $\begin{array}{c}\text { Puntaje } \\
\text { Propuesta } \\
\text { Técnica }\end{array}$ & $\begin{array}{c}\text { Puntaje } \\
\text { Propuesta } \\
\text { Económica }\end{array}$ & $\begin{array}{c}\text { Puntaje } \\
\text { Total }\end{array}$ & Orden \\
\hline Importaciones Alpes Perú SAC & - & - & - & - \\
\hline Dentilab del Perú SRL & 100 & 98.305084 & 99.322034 & 1 \\
\hline Distribuidora Continental 5 SA & 100 & 98.305084 & 99.322034 & 1 \\
\hline
\end{tabular}


Como se puede apreciar, existe un empate en el primer lugar, razón por la cual no se le puede otorgar la buena pro al impugnante, tal como fue solicitado en su petitorio; sino que el Comité Especial debe encargarse de realizar el desempate correspondiente, de acuerdo a Ley.

\subsubsection{Decreto Supremo $\mathrm{N}^{\circ}$ 138-2012-EF}

La segunda norma que naturalmente deroga la anterior, es el D. S. $\mathrm{N}^{\circ}$ 138-2012-EF, publicado el 07 de Agosto de 2012 que dice lo siguiente:

Artículo 62 ${ }^{\circ}$.- Presentación de documentos. Todos los documentos que contengan información referida a los requisitos para la admisión de propuestas y factores de evaluación se presentarán en idioma castellano o, en su defecto, acompañados de traducción oficial o certificada efectuada por traductor público juramentado $\underline{0}$ traductor colegiado certificado, según corresponda, salvo el caso de la información técnica complementaria contenida en folletos, instructivos, catálogos o similares, que podrá ser presentada en el idioma original. El postor será responsable de la exactitud y veracidad de dichos documentos.

Cuando se exija la presentación de documentos que sean emitidos por autoridad pública en el extranjero, el postor podrá presentar copia simple de los mismos sin perjuicio de su ulterior presentación, la cual necesariamente deberá ser previa a la firma del contrato. Dichos documentos deberán estar debidamente legalizados por el Consulado respectivo y por el Ministerio de Relaciones Exteriores, en caso sea favorecido con la Buena Pro.

El presente decreto supremo tiene un segundo artículo complementario que dice:

\section{Artículo $141^{\circ}$.- Requisitos para suscribir el Contrato}

Para suscribir el contrato, el postor ganador de la Buena Pro deberá presentar, además de los documentos previstos en las Bases, los siguientes:

(...)

5. Traducción oficial efectuada por traductor público juramentado de todos los documentos de la propuesta presentados en idioma extranjero que fueron acompañados de traducción certificada. (...) (El subrayado es agregado) 
$\mathrm{Al}$ verse con los problemas comentados anteriormente y con la idea de poder resolverlos, en el segundo decreto supremo, el MEF apela a una extraña fórmula. Durante la presentación de las propuestas, los postores pueden presentar traducciones efectuadas tanto por los TPJ como de un grupo de traductores colegiados ante el Colegio de Traductores del Perú quienes se autodenominan "traductores colegiados certificados" los mismos que no expiden traducciones con valor oficial; es decir legalmente no están facultados para ello, por tanto sus traducciones califican como traducciones privadas en cualquiera de sus denominaciones mencionadas en el punto 1.2.4 del Capítulo I.

El OSCE por su parte deja de lado, sin razón alguna, a los egresados de Institutos como EUROIDIOMAS, ESIT entre otros, donde también se estudia la traducción e interpretación. Igualmente deja de lado a los profesionales que cuentan con otros títulos académicos y que ejercen la traducción como actividad complementaria y/o exclusiva.

Es decir, ahora la ley recurre a los egresados de algunas Universidades que imparten la enseñanza de la traducción. Esta postura al igual que lo que ocurrió con el Reglamento derogado se hace sin ningún criterio académico sólido y también en este caso, la realidad va a hacer que no se pueda cumplir con la normativa al respecto.

\subsubsection{Problemas}

$\mathrm{Al}$ igual que en el decreto anterior, el presente decreto supremo no soluciona el problema del número insuficiente de traductores. Es más, resulta lo inverso. En efecto, con el decreto anterior se tenía TPJ para 9 idiomas, pero con el presente decreto se cuenta con "traductores certificados" solamente para siete idiomas. ${ }^{27}$ Los 7 idiomas que ofrece el CTP son: alemán, francés, inglés, italiano, japonés, portugués y ruso al momento de redactarse el presente trabajo.

Por otro lado, no sabemos cómo se llegaron a colegiar traductores en dicho Colegio en idiomas que normalmente no ofrecen las universidades ya que siempre se han dictado en dichas casas de estudio solo el idioma inglés, francés y alemán; y últimamente el Italiano.

El segundo problema que no ha sido solucionado con el presente decreto es el aspecto de la especialización de los traductores. Esto debido a que cuando se termina con

${ }^{27}$ Recuperado de colegiodetraductores.org.pe/listado-de-traductores-colegiados-certificados/ 
los estudios de la carrera de traducción, se hace sin ninguna especialización y es así como se accede al Colegio de Traductores del Perú.

\subsubsection{Consecuencias}

Al igual que con el primer decreto, con el presente no se llegan a cubrir todos los idiomas en que potencialmente pueden llegar los documentos del extranjero.

En segundo lugar, en cuanto a la especialización, nos encontramos en peor situación que con el decreto anterior. En efecto, el TPJ, al que no se le exige ninguna especialización para postular al cargo, ha podido; sin embargo, durante su ejercicio poder informarse de manera más o menos aceptable de los aspectos legales que inciden en la traducción (nos referimos al aspecto de los sistemas legales vinculados al Derecho Comparado que se presentan en una traducción jurídica) pues ese es su nicho natural, como afirman los estudiosos de la traducción. En otras palabras, ahora se exige que dichos documentos sean traducidos por personas con menos calificaciones que los TPJ.

En este nuevo decreto ya se aceptan dos tipos de traducciones: las oficiales, mejor dicho las públicas (las mismas que son emitidas por los TPJ) como hemos visto y las del "traductor colegiado certificado". El legislador no se da cuenta de que en el fondo está aceptando todo tipo de traducción las "oficiales" y las "no oficiales" las mismas (estas últimas) que pueden ser efectuadas por cualquier traductor sea o no egresado de alguna universidad o instituto, pues es una actividad, mejor dicho, un oficio libre para su ejercicio.

Por tanto, el supuesto "traductor colegiado certificado" es un traductor que certifica (privadamente) las traducciones que emite, pero igualmente y con facilidad se puede afirmar que no son los únicos.

En tercer lugar, las consecuencias son las mismas que se producían con el decreto anterior pues al momento de suscribir el contrato, al postor ganador solo se le permite la presentación de traducciones oficiales para la firma del contrato; algo así como tanto nadar para morir en la playa. 


\section{- Caso 3:}

El 25 de Noviembre de 2013, el Seguro Social de Salud - ESSALUD convoca en Licitación Pública N 024-2013/ESSALUD-RAAR., para la adquisición de "Reactivos de Patología Clínica con Equipo de Cesión en Uso - Área de Hormonas y Mercaderes Tumorales para la Gerencia de Red Asistencial de Arequipa con un valor referencial que en nuevos soles es de S/. 504,484.80. Se presentan dos postores, resultando ganador el consorcio conformado por LAB DEPOT S.A. y BIOGENÉRICOS INTERCAMBIABLES S.A.C. El segundo postor conformado por el consorcio Representaciones Hospitalarias NACHACCOV E.I.R.L. y Corporación Medical BERTH'S S.A.C. impugna la adjudicación ante el Tribunal del OSCE, argumentando que:

El Adjudicatario ha presentado, como parte de su propuesta técnica, documentos en idioma extranjero, a los cuales se adjunta traducciones sin valor oficial. Dichos documentos son los siguientes: i) Certificado $\mathrm{N}^{\circ}$ 2619-5-2012, ii) Certificado de Gobierno Extranjero - Instrumento i6000, iii) Certificado de fabricante. - Certificado N FM 596815 - Certificado de Registro de Sistema de Gestión de Calidad - ISO 9001:2008, iv) Certificado N ${ }^{\circ}$ FM 538536 - Certificado de Registro de Sistema de Gestión de Calidad - ISO 13485:2003., v) Certificado Nº FM 78972 - Certificado de Registro de Sistema de Gestión de Calidad - ISO 13485:2003.

Añade que las traducciones presentan una nota al pie que señala "Traducción simple sin valor oficial", no obstante que, de conformidad con el numeral 1.10 de la Sección General de las Bases, los documentos para la admisión y calificación de propuestas presentados en idioma extranjero, debían estar acompañados de traducción oficial o certificada efectuada por traductor público juramentado o traductor colegiado certificado.

Señala que tanto el Certificado de Fabricante como el Certificado de Gobierno Extranjero constituyen documentos de presentación obligatoria, los cuales debieron estar acompañados de traducción oficial o certificada. Asimismo, los Certificados de calidad adolecen del mismo defecto, los mismos que el Comité Especial del proceso de selección debió desestimar.

Agrega que no es aplicable lo dispuesto en el artículo 41 de la Ley del Procedimiento Administrativo General, en la medida que éste hace referencia a una traducción simple, mientras que la normativa de contrataciones con el Estado requiere documentos con traducciones oficiales o certificadas. 
Así el impugnante solicita que se revoque el otorgamiento de la Buena Pro y que se les otorgue dicha Buena Pro. En uno de sus considerandos (9) el Tribunal sostiene que:

En vista de las conclusiones advertidas, las traducciones de los documentos: Certificate to Foreign Government (Certificado $N^{\circ}$ 2619-5-2012 - Certificado de Gobierno Extranjero), Instrumento i6000 - Certificado de fabricante (Certificate of Manufacture) y los Certificate of Registration (Certificados de Registro de Sistema de Gestión de Calidad) $\mathrm{N}^{\circ}$ FM 596815, $\mathrm{N}^{\circ}$ FM 538536 y FM 78972, no constituyen traducciones oficiales ni certificadas, por no cumplir con las condiciones señaladas en las normas correspondientes, no advirtiéndose el cumplimiento de lo establecido en el artículo 62 del Reglamento.

Por tanto, en vista que las traducciones observadas corresponden a documentos que fueron de presentación obligatoria, corresponde descalificar la propuesta técnica del Adjudicatario.

Finalmente, mediante Resolución $\mathrm{N}^{\circ}$ 323-2014-TC-S2, se declara desierta la Licitación Pública N 024-2013/ESSALUD-RAAR. Pensamos que el Tribunal comete un error al sostener que la traducción simple es distinta de la traducción certificada, cuando en el fondo ambas son traducciones privadas (no merecen fe pública). El hecho que hayan sido emitidas por distintos traductores es irrelevante.

\subsubsection{Decreto Supremo $\mathrm{N}^{\circ}$ 080-2014-EF}

La tercera y penúltima norma expedida sobre traducción, también derogada por el actual RLCE, es la contenida en el Decreto Supremo $N^{\circ}$ 080-2014-EF, el mismo que fue publicado el 22 de Abril de 2014. Dicha norma señala:

\section{Artículo 62.- Presentación de documentos}

Todos los documentos que contengan información referida a los requisitos para la admisión de propuestas y factores de evaluación se presentan en idioma castellano o, en su defecto, acompañados de traducción oficial o sin valor oficial efectuada por traductor público juramentado o traducción certificada efectuada por traductor colegiado certificado, salvo el caso de la información técnica complementaria contenida en folletos, instructivos, catálogos o similares, que puede ser presentada 
en el idioma original. El postor es responsable de la exactitud y veracidad de dichos documentos.

Las Entidades someten a fiscalización posterior conforme a lo previsto en el artículo 32 de la Ley No 27444, Ley del Procedimiento Administrativo General, la documentación, declaraciones y traducciones presentadas por el ganador de la Buena Pro. (el subrayado es agregado)

En su tercera modificación de la regulación de este tema, el MEF da un salto a la orilla opuesta y no le queda más remedio que aceptar cualquier tipo de traducción pues no sabe cómo resolver los problemas que se han estado presentando. Es decir, actualmente se aceptan traducciones emitidas tanto por los TPJ como por los traductores colegiados, en cualquier instancia del proceso de selección, sean oficiales o no oficiales, sea al momento de efectuar las propuestas como para firmar el contrato respectivo.

Pero este cambio tiene tres aspectos negativos. En primer lugar, perjudica a los TPJ en nuestra opinión ya que los mismos, como dijimos, son más solventes en esta materia que los traductores colegiados certificados, que son generalistas. La razón es muy sencilla: ahora los postores van a recurrir a los traductores colegiados ya que no están sujetos a ningún protocolo que demore la expedición de la traducción. En segundo lugar, con esta nueva redacción lo que se consigue es emitir una norma discriminatoria en nuestra opinión, pues se está relegando a otros traductores sin mayor justificación quienes tienen el mismo derecho constitucional al trabajo y a la competencia al ser la traducción un oficio libre y no cautivo para su ejercicio. En tercer lugar, el aceptar que solo pueden ofrecer sus servicios los TPJ y los traductores colegiados viene a constituir una auténtica barrera de ingreso al mercado para otros traductores especializados, debido a que no existe razón alguna que justifique tal restricción.

\subsubsection{Problemas}

Los problemas persisten en primer lugar, en tanto no hay traducciones para idiomas para los cuales no hay ni TPJ ni "Traductores certificados". 
El segundo problema, sigue siendo la falta de especialización tanto de los TPJ como de los autodenominados "traductores certificados".

El tercer problema, en nuestra opinión, es que se ha dado una norma discriminatoria ya que el OSCE está ahora aceptando cualquier tipo de traducción sin importar su naturaleza de oficialidad, que como se sabe estaría reservado a los TPJ aunque de manera igualmente altamente cuestionable.

\subsubsection{Consecuencias}

En primer lugar, al no haber el número suficiente de traductores para cubrir todos los idiomas, seguirá la ausencia de presentación de documentos que no podrán ser presentados al igual que con los decretos anteriores, incluso apelando a las traducciones especiales por lo engorroso de su tramitación. O si los han presentado con traducciones simples u otras similares correrán el riesgo de que les anulen el proceso y de que los inhabiliten.

\subsubsection{Decreto Supremo $N^{\circ}$ 350-2015-EF}

Esta es la novísima norma que reglamenta la nueva Ley de Contrataciones del Estado (LCE), Ley $\mathrm{N}^{\circ}$ 30225. Dicho Decreto Supremo fue promulgado el 10 de Diciembre de 2015. En su artículo 38, señala:

\section{Artículo 38.- Idioma de la documentación y otras formalidades}

Los documentos que acompañan a las solicitudes de precalificación, las soluciones técnicas, las expresiones de interés, las ofertas y cotizaciones, según corresponda, se presentan en idioma castellano o, en su defecto, acompañados de traducción oficial o sin valor oficial efectuada por traductor público juramentado o traducción certificada efectuada por traductor colegiado certificado, salvo el caso de la información técnica complementaria contenida en folletos, instructivos, catálogos o similares, que puede ser presentada en el idioma original. El postor es responsable de la exactitud y veracidad de dichos documentos. Las solicitudes de precalificación, las soluciones técnicas, expresiones de interés, ofertas y cotizaciones deben llevar la rúbrica del postor o de su representante legal, apoderado o mandatario designado para dicho fin. (el subrayado es agregado) 


\subsubsection{Problemas.}

No cambia la óptica de la LCE con la reglamentación precedente. Como vimos, la ley hoy acepta todo tipo de traducción y en cualquier instancia. La fuerza de los hechos ha conseguido que los servicios de traducción empiecen a dejar de ser discriminados por la administración. La ley (en sentido amplio) no lo hace y se espera que la administración no lo haga tampoco aunque la apertura del reglamento en cuestión no es completa, como ya se ha visto.

\subsubsection{Consecuencias.}

Al igual que en los otros casos, las consecuencias son las mismas: la falta de especialización de los traductores impide contar con traducciones que merezcan confianza. El número insuficiente de idiomas impide traducir documentos que se encuentran en otros idiomas (el caso de la Universidad Cayetano Heredia es ilustrativo al respecto) y, en el caso específico de los TPJ, la morosidad en su labor impide contar con traducciones a tiempo, debido a los muchos pasos que tiene que seguir el TPJ para expedir sus traducciones.

Finalmente, pensamos que dicho artículo 38 contraviene el Principio de libertad de concurrencia contenido en el artículo 2 de la nueva LCE, Ley $\mathrm{N}^{\circ} 30225$ ab initio que dice:

\section{Artículo 2. Principios que rigen las contrataciones}

a) Libertad de concurrencia. Las Entidades promueven el libre acceso y participación de proveedores en los procesos de contratación que realicen, debiendo evitarse exigencias y formalidades costosas e innecesarias. Se encuentra prohibida la adopción de prácticas que limiten o afecten la libre concurrencia de proveedores.

Como se sabe, incluso las traducciones de los miembros del CTP requieren la legalización de sus firmas ante el Ministerio de Relaciones Exteriores.

\subsubsection{La posición del OSCE sobre las traducciones}

Como se puede observar, el OSCE en cuanto a traducciones se refiere, se ha ido de un extremo al otro. Se ha ido del requerimiento de traducciones oficiales con el primer decreto del año 2008 hasta el actual decreto que acepta tanto traducciones oficiales como 
no oficiales, es decir todas en el fondo. ¿Pero, cuáles han sido las razones del legislador para legislar como lo ha hecho?

En cuanto al primer decreto, suponemos que apela a la oficialidad de las traducciones y sus supuestas ventajas, pero ello ha demostrado ser insuficiente, ya que en los pronunciamientos que ha dado el OSCE nunca ha tocado este argumento. Por tanto, la oficialidad de las traducciones, al menos para esta actividad empresarial, no es razón suficiente como requisito.

Otro hecho que avala nuestro comentario, es que en el segundo decreto se incluyó a los autodenominados "traductores certificados" los mismos que no expiden traducciones con carácter oficial. En consecuencia, la razón o razones que mueven al OSCE a regular como lo ha hecho son otras. En efecto, la respuesta aparece en su Opinión 027-2013 página 3, donde dice literalmente:

Como se aprecia, dada la importancia de los documentos que se presentan para acreditar los requisitos para la admisión de las propuestas y los factores de evaluación -pues estos determinan qué proveedores pueden seguir participando en el proceso de selección, así como su calificación, respectivamente-, la normativa de contrataciones del Estado ha previsto formalidades especiales cuando dichos documentos sean presentados en idioma distinto al castellano, a efectos de salvaguardar no solo su validez, sino también la calidad de la información de estos detallan.

En consecuencia, lo que el OSCE requiere son traducciones que de alguna manera le garanticen que los documentos sean válidos, lo que no tiene que ver con la traducción, y que el contenido del texto sea igualmente de calidad. Nosotros pensamos que el MEF se equivoca una vez más. En efecto, debido a una práctica habitual y no tan sana que digamos, los traductores a los que hace referencia el OSCE tienen la costumbre de colocar al final de la traducción una leyenda como la que se indica:

Yo, $[\ldots]$, certifico que la presente es una traducción fiel y correcta del documento adjunto. La presente traducción no debe considerarse como reconocimiento de la autenticidad del documento adjunto.

Esta es la razón fundamental en la que el OSCE se apoya, es decir que las traducciones sean buenas, de buena calidad o idóneas. Se entiende que los traductores que escoge el Reglamento de la LCE sean mejores que los demás, sean más competentes. 
Esto es más significativo en el caso de las traducciones efectuadas por los TPJ en nuestro país. En efecto, en el Manual de Procedimientos del Reglamento de Traductores Públicos Juramentados (Resolución Ministerial Nº 0497/RE del 30 de Junio de 2004), se puede leer en el apartado 2. DE LAS TRADUCCIONES, inciso 2.1., lo siguiente:

Los Traductores Públicos Juramentados deberán:

$(\ldots)$

g) Concluida la traducción, estampar al pie de la última página un sello legible con el siguiente tenor: "El infrascrito, Traductor Público Juramentado, certifica que la presente traducción es fiel y correcta del texto original en idioma adjunto.

Esta traducción no debe interpretarse como reconocimiento de la autenticidad del documento traducido.

En fe de lo cual firmo y sello en ....... a los ....días del mes de de.

Estampará sellos de igual tenor en los idiomas extranjeros pertinentes para las traducciones del castellano a tales idiomas. (El subrayado es agregado)

Es más, dichas características (fidelidad y corrección) se esgrimen como justificación por la cual algunos Estados han creado una figura como la del Traductor Oficial el mismo que daría seguridad jurídica al sistema por el contenido de documentos redactados en otros idiomas, de tal manera que los usuarios, especialmente las autoridades, dan por descontado que la traducción oficial o pública que tienen entre manos refleja de manera fiel y correcta el mensaje del texto adjunto que va en original en otra lengua. Pero ¿Cuán cierto es esto?

Empecemos a analizar el tema recurriendo al Diccionario de la Lengua Española. Sobre el adjetivo Fiel dice:

FIEL (Del lat. fidelis).

1.- adj. Que guarda fe, o es constante en sus afectos, en el cumplimiento de sus obligaciones y no defrauda la confianza depositada en él.

2.- adj. Exacto, conforme a la verdad. Fiel traslado. Memoria fiel.

3.- adj. Que tiene en sí las condiciones y circunstancias que pide el uso a que se destina. Reloj fiel.

4.- adj. Por antonom. Cristiano que acata las normas de la Iglesia. U. t. c. s. 
5.- adj. Creyente de otras religiones.

(RAE)

Para nuestro análisis lo que interesa es básicamente la acepción 2, lo que aplicado a la traducción, quiere decir que el texto original se verá reflejado con consideraciones de veracidad y fidelidad en la versión efectuada por el traductor, lo cual es una falsa apreciación de las personas ajenas a la traducción. Dejemos hablar a los especialistas al respecto.

LO QUE DICEN LOS ESPECIALISTAS.- Para averiguar si efectivamente es posible logar una traducción fiel y correcta hemos leído lo que dicen algunos de los especialistas más representativos de esta disciplina. Roberto Chiesa (Abogado y Traductor Público) en una entrevista que le hiciera la Revista Lecciones y Ensayos, ante la pregunta ¿Qué es la traducción?, manifiesta:

\section{1.- ENTREVISTA A RICARDO CHIESA}

Si buscamos una respuesta que tenga que ver cómo uno ejerce el trabajo de traducción, a mí me gusta citar una frase del libro Thinking Spanish Translation, que dice que el proceso de traducción consiste más en minimizar las diferencias que en maximizar las semejanzas. Y eso significa reconocer que hay una brecha y que hay que salvarla, lo cual echa por tierra con la noción de la transposición total de la equivalencia o la idea de correspondencia absoluta. $\underline{\text { Admite como parte integrante de la traducción la noción de pérdida, como un }}$ elemento inherente a la traducción. Y el traductor tiene que avenirse a eso. (2009, p. 357).

(El subrayado es agregado)

En esa misma línea, desde Canadá, Jean-Claude Gémar en una entrevista que le hiciera la Revista del Colegio de Traductores Públicos de la Ciudad de Buenos Aires sobre la fidelidad dice: "La fidelidad, en traducción es un mito, una utopía, un objetivo al que se aspira pero nunca se alcanza." (Gémar, 2010, p. 5).

Ya, más específicamente sobre el área jurídica de documentos que vienen o van a países del Common Law, los mismos que constituyen irónicamente el grueso de las traducciones públicas u oficiales en nuestro país donde se hace necesaria la exigencia de 
fidelidad y corrección, dice María Teresa Martínez (1994): “La traducción de textos jurídicos del inglés al castellano y viceversa es una verdadera utopía ya que la realidad de los valores ideológicos que gobiernan cada uno de los sistemas es exclusivo de cada uno de ellos (p. 1).

Finalmente, dice el especialista Yatenciy Bonilla:

Toda traducción es un acto de interpretación, acto hermenéutico (...). Nunca hay traducción perfecta, los lingüistas dicen que una traducción de una lengua moderna a otra lengua moderna, la traducción más perfecta que se llega a conservar la intencionalidad del lenguaje original es el $85 \%$. Esto quiere decir que la traducción de una lengua moderna a otra lengua moderna se pierde un $15 \%$ de la intencionalidad de la lengua original. ${ }^{28}$

Esto en cuanto a la Fidelidad. Veamos ahora sobre la Corrección.

CORRECCIÓN.- Sobre este tema dice la Real Academia de la Lengua:

Corrección: Del lat. correctǐo, -ōnis.

1.- f. Acción y efecto de corregir (enmendar lo errado).

2.- Cualidad de correcto (libre de errores o defectos).

3.- Cualidad de la persona de conducta irreprochable.

4.- Reprensión o censura de un delito, de una falta o de un defecto.

5.- Alteración o cambio que se hace en las obras escritas o de otro género, para quitarles defectos o errores, o para darles mayor perfección.

(RAE).

Lo más aplicativo a la traducción es la acepción 2. Este es un aspecto más relacionado con lo lingüístico que otro aspecto, pero tiene su importancia debido a que en algunos casos puede ayudar a interpretar el texto (método gramatical).

Sin embargo, no hay consenso sobre cómo traducir correctamente, algunos prefieren una cierta manera que otros no tendrían en cuenta. Para decirlo en pocas

${ }^{28}$ Recuperado de http://youtu.be/PF2h86a9pzU, a partir del minuto 7. 
palabras, se supedita casi de manera invariable el texto que se tiene entre manos a la elección que hace el traductor sobre lo que él considera correcto.

Es decir, la corrección tiene su lado bueno, pero tampoco es determinante. Es importante pero está subordinada a la fidelidad. Haciendo un paralelo con una figura legal se puede decir que la fidelidad es lo principal y la corrección es lo secundario.

Es más, se puede aplicar el aforismo jurídico de que "lo secundario sigue la suerte del principal". Si una traducción es fiel, se puede perdonar que no sea correcta (lingüísticamente hablando) y no al revés; si la traducción no es fiel al texto de partida ¿qué importa que sea correcta lingüísticamente hablando?

Hay algunas agencias de traducción que en un esfuerzo por lograr la ansiada fidelidad y corrección contratan revisores y/o estilistas y lo único que logran es encarecer el producto final. Por tanto, nosotros sostenemos que lo que una traducción debe perseguir es que la brecha que se pierde no sea más grande de lo que intrínsecamente es.

\subsection{Alternativas de solución a los problemas presentados}

Nosotros, al igual que en otras latitudes, somos de la opinión de que no hay razón alguna para que se restrinja esta actividad a ciertas personas como los TPJ o los autodenominados "traductores certificados" ya que existen otros profesionales -incluso con mayores méritos- para realizar buenas traducciones, más aun ahora que sabemos que es una actividad que no puede ser garantizada por nadie.

Por otro lado, y tocando directamente el tema, hasta el momento no existe una Facultad de Traducción stricto sensu como erróneamente cree el Ministerio de RREE así como otras autoridades, lo que podría dar lugar a pensar de alguna manera que cuentan con las calificaciones necesarias.

El único caso más cercano es el de la Universidad Femenina del Sagrado Corazón, la misma que cuenta con una Facultad de Traducción, Interpretación y Ciencias de la Comunicación, lo que abona a nuestro favor en el sentido de que la traducción es una actividad igual o similar a la del periodismo. Es decir es aplicable el apotegma de "donde hay la misma razón, hay el mismo derecho". Si el ejercicio del periodismo es libre, igual debe ocurrir con la traducción. 
En las demás universidades, los traductores egresan de una Facultad de Lenguas Modernas como es el caso de la Universidad Ricardo Palma lo que confirma la tendencia predominante lingüística de esta actividad en el Perú. En la Universidad Cesar Vallejo se estudia traducción en una Escuela de Idiomas y en la Universidad de Ciencias Aplicadas - UPC se estudia traducción en la Facultad de Ciencias Humanas.

\subsubsection{Registro de Traductores}

Para mejorar el servicio de traducción, hacemos la propuesta de que se cree un Registro que acoja a diversos traductores especialistas por las siguientes consideraciones. En resumen, se puede fácilmente colegir que en el país y en el mundo solamente existen dos grupos de traductores:

i) los traductores especialistas, que son los que cumplen con el perfil dictado por los investigadores y estudiosos de esta actividad (fundamentalmente extranjeros), como es el dominio del idioma nacional, dominio del idioma extranjero y conocimiento del campo que se intenta traducir. Ellos son los verdaderos traductores, pero es difícil lograr dichos requisitos, pues en el fondo sería ejercido por personas que tienen prácticamente dos profesiones en una, especialista en su campo y traductor, sea por experiencia o producto de un estudio regular a nivel universitario o técnico.

ii) los traductores generalistas, que como su nombre indica, traducen todo tipo de texto desde poesía, pasando por los textos científicos y jurídicos. Sus estudios son básicamente lingüísticos y tratan de especializarse llevando algunos cursos en algún campo del conocimiento para informarse de alguna manera sobre dichos campos. Son estos traductores que dependen de diccionarios, de bases de datos, de listas terminológicas, de consultas con los especialistas en gran medida para culminar con su trabajo. Pero que son necesarios dado el volumen del trabajo que se debe hacer.

Los países que tienen una mayor tradición en traducción son conscientes de estos aspectos y reconocen el lugar que le corresponde a cada uno. En nuestro país, no sucede este enfoque, se piensa que los traductores generalistas son los profesionales que pueden lidiar con todo tipo de texto y como se ha visto a lo largo de todo nuestro trabajo, ello no es del todo cierto. 
La ley también ha validado este desconocimiento. Existe una Ley que alberga a los Traductores Generalistas, la Ley $\mathrm{N}^{\circ}$ 26684, ley de creación del Colegio de Traductores del Perú (CTP) que solo admite a los licenciados en traducción. Igualmente existe una Ley que regula la actividad de la traducción oficial o público o como se quiera llamar, nos referimos al Decreto Ley $\mathrm{N}^{\circ} 18093$ y su modificatoria Decreto Legislativo $\mathrm{N}^{\circ} 712$, pues tienen un cierto dominio del derecho. El hecho que haya un par de abogados que ejercen como TPJ es producto de la casualidad y no de la exigencia hecha por el Ministerio de Relaciones Exteriores que se encarga de regular esta disciplina.

Esta diferenciación tiene justificación recogida por la experiencia. No es casualidad que los textos universitarios y otros especializados no se traduzcan en el país, por falta justamente de personas calificadas. No es casualidad que se realicen eventos sobre traducción especializada las mismas que son dirigidas especialmente a los generalistas para cubrir las brechas producto de una preparación inacabada.

Sin embargo, no existe una Ley que regule la labor del verdadero traductor, aquel que cumple con los 3 requisitos que proclaman los estudiosos de esta actividad que en algunos lugares ya se perfila como ciencia: la Traductología.

Puede parecer irónico, pero es la realidad. Para cubrir este vacío, proponemos la creación de un Registro donde deben aparecer los nombres de los Traductores Especialistas por el activo que tienen de conocer un campo del conocimiento cualquiera que éste sea. Ellos ya existen pero están diseminados en el país, ellos trabajan como tales y a veces asesorando a los traductores generalistas y en no pocos caso haciéndoles las tareas que les corresponderían si fueran reconocidos. Ubicarlos es poco menos que imposible.

Por ello, un Registro no solo les haría justicia, sino que significaría un ahorro en tiempo y dinero tener a alguien con tan solo consultar un registro que podría estar depositado en un Ministerio como el de Cultura (no necesariamente) que es el mismo que también cuenta también con un registro de traductores en las diversas lenguas indígenas que existen en el Perú.

De esta forma, se haría justicia a profesionales como la Dra. Noemí Vizcardo, doctora en derecho, la misma que ejerce como traductora e intérprete en la combinación de lenguas español-quechua, una profesional con calidades que no la tiene ni el Colegio de Traductores del Perú ni los TPJ, pues la ley se lo impide. La Dra. Vizcardo es la única 
persona que ha traducido (hasta donde sabemos) la Constitución de 1993 al quechua, divulgando así información valiosa para los quechua hablantes.

Un Registro de este tipo al ser de fácil acceso, reduce considerablemente los costos de transacción para que una sociedad sea más eficiente en el ejercicio de este oficio que es al mismo tiempo una profesión y un arte.

Con dicho registro en esta actividad de la traducción, nos pondríamos a la par de otros países, o tal vez mejor, ya que otros países no tienen un registro como el que esbozamos. En estos tiempos donde la información se ha multiplicado por diversas razones, contar con un traductor, pero de un experto o especialista ayuda al desarrollo nacional, sin duda. No se puede esperar a que se importen textos traducidos y que cuando lleguen es posible que esa información ya se encuentre desfasada.

Dicho registro no eliminaría a los demás traductores ya que los usuarios pueden apelar a instituciones que cuentan con traductores especializados para cada tema que existe en el mercado, con mayor razón debido a que ahora sabemos que el MEF no se inclina necesariamente por traducciones oficiales.

Otra alternativa al Registro, es que exista la posibilidad académica para personas que dominan un idioma puedan informarse a través de un pos grado o un diplomado sobre algunos aspectos básicos de la traducción dentro de su especialidad. Esto no es nuevo, en España el estudio de la traducción se da a nivel de pos grado.

\subsubsection{En el plano legislativo}

Aparte del Registro propuesto en el acápite anterior, la iniciativa se concretaría a través de una norma que pueda ser recogida por el órgano legislativo correspondiente.

Sin embargo, las iniciativas legislativas tardan en concretarse. Una opción alterna sería la de que rija plenamente el artículo 41 (41.1.2) de La Ley $\mathrm{N}^{\circ} 27444$ o del Procedimiento Administrativo General, que dispone el uso de la traducción simple para todas las entidades públicas.

La disposición de dicha Ley $\mathrm{N}^{\circ} 27444$ es bastante buena y que de haberse usado de manera supletoria hubiera evitado los problemas que comentamos. El único defecto es de tipo terminológico; es decir, en vez de la traducción "simple" se hubiera apelado 
mejor a la traducción "certificada". En efecto, la Ley N²7444 habla de una traducción simple, pero hace una descripción de lo que sería una certificada

Según la costumbre, la traducción certificada es la que lleva el agregado de una declaración del autor del documento en la que menciona algunos aspectos de su trabajo. Dicha certificación puede ser de naturaleza privada u oficial, esto último sucede en los países donde los funcionarios públicos se encargan de efectuar traducciones como en Chile. Generalmente, se menciona que es una traducción fiel y correcta, entre otras consideraciones. En otros casos, el autor declara ser una persona competente para realizar el trabajo de traducción y declara que ha efectuado un trabajo diligente.

En el caso específico de la Ley de Contrataciones del Estado, lo mejor sería la modificación del artículo $38^{\circ}$ del Reglamento el que tendría la siguiente redacción:

\section{Artículo 38.- Idioma de la documentación y otras formalidades}

Los documentos que acompañan a las solicitudes de precalificación, las soluciones técnicas, las expresiones de interés, las ofertas y cotizaciones, según corresponda, se presentan en idioma castellano o, en su defecto, acompañados de traducción certificada con la indicación y suscripción de quien oficie de traductor debidamente identificado, salvo el caso de la información técnica complementaria contenida en folletos, instructivos, catálogos o similares, que puede ser presentada en el idioma original. El postor es responsable de la exactitud y veracidad de dichos documentos. Las solicitudes de precalificación, las soluciones técnicas, expresiones de interés, ofertas y cotizaciones deben llevar la rúbrica del postor o de su representante legal, apoderado o mandatario designado para dicho fin. (El subrayado es agregado)

La opción de exigir traducciones certificadas se explica -además de lo mencionado líneas arriba- porque ayuda a la pronta identificación del autor de la traducción, lo que ayuda a solucionar algún conflicto de alguna manera.

Cuando hacemos referencia a la traducción certificada, estamos incluyendo en dicha definición a las tres variantes mencionadas en la página 24 del presente trabajo; es decir: i) las que mencionan los datos del autor, que en casos de agencias o estudios de traducción se obtienen de hojas membretadas y sellos, así como las firmas de los autores del documento, ii) las que tienen la firma legalizada por Notario, iii) las personas que 
cuentan con una certificación de alguna entidad sea privada o pública al encontrarse registrada en dichas entidades.

Adicionalmente, la definición de traducción certificada, debe aparecer en el Glosario, que para el efecto tiene el Reglamento bajo comentario. Por tanto, al final del Reglamento, se debe hacer una referencia a dicha traducción como sigue: Anexo único ANEXO DE DEFINICIONES:

Traducción certificada: Tipo de traducción que: i) presenta los datos del autor de la traducción como nombre, firma, dirección, teléfono y otros, ii) traducción que contiene la firma del autor debidamente legalizada, y iii) traducción efectuada por una persona certificada como competente para efectuar traducciones, por parte de alguna institución privada o pública.

Esto permite darle cierta formalidad al documento. Además de no ser muy restrictiva la medida, permite la participación de un mayor número de personas que ofrecerían sus servicios en el mercado.

Por otro lado y en concordancia con nuestro planteamiento de no excluir a nadie. Una vez abierto el Registro, el usuario -público o privado- está en libertad de elegir al mejor que se adecue a sus necesidades. Si desea un generalista o un experto ya sabría a dónde acudir. Si desea traducir un documento para su consulta o para un análisis e interpretación no solo lingüístico, sino jurídico (en el caso de textos jurídicos) ya sabría dónde acudir.

Es el usuario el que tiene la palabra y la competencia, la sana competencia tanto en calidad como en precio, al final a quien debe favorecer es al país. Con una ley tal como la que proponemos solo tiene como fin, poner orden donde hay desorden. Poner conocimiento donde hay nubarrones de confusión. Finalmente, llamar la atención de los que tiene responsabilidad de preparar a los traductores que realicen cambios que optimicen esta disciplina, pues hay, todavía, mucho que hacer en este campo.

Cuando el presente trabajo se encontraba en su fase de corrección y trámites para fijar fecha de sustentación, apareció en El Peruano el 19 de marzo de 2017 el D.S. 0562017-EF cuyo art. $38^{\circ}$ contiene una redacción muy parecida a nuestra propuesta legislativa. La única salvedad es el cambio a traducciones simples que son aquellas que no contienen los datos del traductor, aparte de eso son iguales en el fondo, es decir son traducciones de naturaleza privada. Este es el nuevo artículo $38^{\circ}$ : 


\section{Artículo 38.- Idioma de la documentación y otras formalidades.}

38.1. Los documentos que acompañan a las solicitudes de precalificación, las soluciones técnicas, las expresiones de interés, las ofertas y cotizaciones, según corresponda, se presentan en idioma castellano o, en su defecto, acompañados de traducción simple con la indicación y suscripción de quien oficie de traductor debidamente identificado, salvo el caso de la información técnica complementaria contenida en folletos, instructivos, catálogos o similares, que puede ser presentada en el idioma original. El postor es responsable de la exactitud y veracidad de dichos documentos.

38.2. Las solicitudes de precalificación, las soluciones técnicas, expresiones de interés, ofertas y cotizaciones deben ser suscritas por el postor o por su representante legal, apoderado o mandatario designado para dicho fin." (El subrayado es agregado) 


\section{CONCLUSIONES}

- Aparte del conocimiento de idiomas, no se requiere llevar estudios formales de traducción para poder realizar traducciones ni para ejercer dicho oficio. Tampoco es necesario conocer las supuestas teorías científicas de la traducción.

- En el caso de textos especializados, además de los idiomas, es indispensable que el traductor conozca el campo del conocimiento que intenta traducir.

- En el caso de traducción de textos jurídicos, el traductor deberá conocer de manera suficiente los sistemas legales implicados en la traducción de dichos textos.

- Los denominados Traductores Oficiales y/o Públicos son en el fondo traductores especializados en materia jurídica debido a que sus traducciones se efectúan en documentos formales que deben ser tramitadas ante entidades judiciales $y$ administrativas principalmente porque producen efectos legales.

- La razón que esgrime el OSCE es una supuesta idoneidad de los traductores que menciona en sus normas. Por tanto, el carácter oficial de la traducción no es la principal razón de su exigencia. Ello explica la aceptación de "traducciones certificadas" las mismas que no son oficiales ni conllevan fe púbica al igual de traducciones efectuadas por TPJ sin las legalizaciones oficiales.

- La supuesta idoneidad de los traductores que menciona el OSCE en sus opiniones es que las traducciones sean "fieles y correctas" características que hacen que una traducción merezca credibilidad.

- Los estudiosos y especialistas en traducción están de acuerdo en que es imposible obtener una traducción fiel y correcta. Prácticamente es un consenso que en el proceso de la traducción se pierde un $15 \%$ con respecto al documento original en el mejor de los casos. Es decir, la brecha es considerablemente grande.

- Ningún traductor sea oficial o no oficial puede garantizar a entera satisfacción una traducción fiel y correcta. Por tanto, la función de cualquier traductor será que la brecha que se pierde no sea más alta de lo que normalmente es. 
- Por sus habilidades y competencias para traducir, los traductores más idóneos para cumplir con dicha tarea son: en primer lugar, los especialistas en algún campo del conocimiento y que saben de traducción. En segundo lugar están los especialistas en algún campo aunque no sepan de traducción. En tercer lugar, están los traductores (de carrera) que cuentan con una especialización. En último lugar, están los traductores (de carrera) que no tienen ninguna especialización.

- La Ley de Contrataciones, sus Reglamentos y el OSCE apelan a los traductores que ocupan el $3^{\circ}$ y $4^{\circ}$ lugar de la escala mencionada en el punto anterior y deja de lado sin justificación alguna a los que están en $1^{\circ}$ lugar y $2^{\circ}$ lugar. 


\section{RECOMENDACIONES}

- La creación de un Registro depositado en algún Ministerio, como el de Cultura aunque no necesariamente. Dicho Registro debe recoger al traductor por especialidades.

- Para acceder a dicho Registro, el interesado debe demostrar su conocimiento tanto de su área de estudio como de traducción, además del conocimiento del idioma. El conocimiento de traducción no tiene que ser teórico sino práctico, por tanto una experiencia de 5 años puede ser suficiente para cumplir con dicho requisito.

- La capacitación de los traductores especializados puede estar a cargo de expertos en los diversos temas, de Universidades o de instituciones como APETEC, la asociación Juristas-Lingüistas Asociados o de otros expertos de probada solvencia.

- Modificar las actuales normas que regulan las traducciones ante el OSCE y permitir a otros profesionales competir en igualdad de condiciones con los demás traductores que existen en el mercado.

- Derogar expresamente la categoría del cargo de TPJ que como se ha probado no tiene razón de ser su existencia. 


\section{REFERENCIAS}

Ayasta González, J. (1991). El Derecho Comparado y los sistemas jurídicos contemporáneos, Lima: Ediciones RJP.

Borja, Albi, A. (1997). La Traducción Jurídica: didáctica y aspectos textuales. Universitat Jaume. Recuperado de http://cvc.cervantes.es/lengua/aproximaciones/borja.htm

Córdova Schaefer, J. (2012). La Nueva Ley de Contrataciones del Estado - Estudio Sistemático. Lima: Pub. Renzo R. Cayetano.

CABRERA, I., HORMANN, P, y otros. (1991). Investigación en traducción: planteamientos y perspectivas. Santiago de Chile: Pontificia Universidad Católica de Chile.

CARETAS, Revista $N^{\circ}$ 1750, 05 de Diciembre de 2002, "ENROQUE NIPÓN. Recuperado de: http://www.caretas.com.pe/2002/1750/secciones/marfon.phtml

Colegio de Traductores del Perú. Revista Institucional Traducteando. Número 4.

CONGRESO MUNDIAL DE TRADUCCION ESPECIALIZADA. (8-13 Diciembre, 2008).

Recuperado de. http://unilat.org/Library/Handlers/File.ashx?id=5154ac8d-935d-4611-9c93de7fb898ff09

Cooper, H.H.A. (1967). Diez Ensayos sobre el Common Law. Lima: Edit. Universo.

Cuñado, F. y Gaméz R. (2015). Traducción Jurídica. Recuperado de www.traduccionjuridica.es

DELISLE, J. y BASTIN, G. (1997). Iniciándose a la Traducción. Caracas: Universidad de Venezuela.

ESTEVEZ EGUIAGARAY, C. (1999). La colaboración con profesionales de los campos específicos en la Traducción Especializada. Lengua y Cultura. Estudios en torno a la traducción. Madrid: Vega, M. y R. Martín Gaitero (Eds), 407 - 413.

Fernández Cozman, C. (06 de Octubre de 2008). Variedades. Semanario del Diario Oficial. El Peruano. p. 23. 
Garner, B. A. (2014). Black's Law Dictionary (10 ed.). Minnesota, Thomson West.

Hurtado Albir, A. (2001). Traducción y Traductología. Introducción a la Traductologia. Madrid: Ediciones Cátedra (Grupo Anaya, S.A.).

Kerby, J. (1982). La traduction juridique, un cas d'èspece. Québec: LANGAGE DE DROIT ET TRADUCTION - The Language of the Law and Translation, Départment de linguistique et philology de l'Université de Montréal.

Lecciones y Ensayos, (2009). Entrevista al traductor Ricardo Chiesa, $\mathrm{N}^{\circ}$ 86, pp. 377-403. Recuperado de http://www.derecho.uba.ar/publicaciones/lye/revistas/86/16entrevista-a-chiesa.pdf

Martínez, L. A. y Guilman, S. La figura del Traductor Público en la República Argentina. Recuperado de www.cttic.org/ACTI/2004/papers/Ponencia_\%20MartinezGuilman.pdf

Martínez, M. T. (1994). El Derecho Penal en los Estados Unidos y el rol del intérprete de Corte. Actas. Lima: Traductores Asociados S.R.L. (1-10).

Mayoral Asensio, R. (2014). ¿Cómo se hace la traducción jurídica? Recuperado de www.ugr.es/ greti/puentes/puentes2/02-articulo.pdf

Mayoral Asensio, R. Lenguajes de Especialidad y Traducción Especializada. La Traducción Jurídica. Recuperado de http://www.ugr.es/ rasensio/docs/LSP_y_traduccion.pdf

Monteagudo, M. A. (30 de Agosto de 2012) Diario. El Comercio, p. A24.

Morán, G. (2002). El Derecho Comparado como disciplina jurídica: la importancia de la investigación y la docencia del Derecho Comparado y la utilidad del método comparado en el ámbito jurídico. Anuario da Facultade de Dereito 6 (2002), 501530. Recuperado de http://bibliotecanonica.net/docsaf/btcafj.pdf

Muñoz Martin, J. F. y Valdivieso Blanco, M. ( ${ }^{\circ}$ 12, Diciembre, 2006). Traductores y Especialistas en la Unión Europea. Hacia un binomio integrador. Revista Electrónica de Estudios Filológicos. Recuperado de http://www.um.es/tonosdigital/znum12/secciones/tritonos\%20ATraductores $\% 20 \mathrm{y} \% 20$ especialistas.htm 
Pastore-Alinante de Fernández Baca, Luisa. (2010). Los traductores y la traducción en el Perú: de dónde venimos. Recuperado de http://www.atpppperu.blogspot.com

Reding, V. (5 de Julio de 2013). Recuperado de www.elgasconjurado.com/2013/07/05/nuevo-proyecto-de-reglamento-quesuprime-las-traducciones-juradas-para-documentos-publicos/

Revista del Colegio de Traductores Públicos de la Ciudad de Buenos Aires, N 103, 2010.

Tupac Yupanqui, D. (29 de Setiembre de 2008). Variedades. Semanario del Diario Oficial. El Peruano. P. 18-19.

Wright, Susan. (2015). From Academic Comparative Law to Legal Translation in $\begin{array}{llll}\text { Practice. } & \text { Recuperado http://www.uni- }\end{array}$ kassel.de/ dippel/justitia/proc/08\%20Wright,\%20Translation.pdf 


\section{BIBLIOGRAFÍA}

American Translators Association. (1994). Professional Issues for Translators and Interpreters. Philadelphia: John Benjamins Publishing Company Amsterdam.

Antequera Parilli, R. y Ferreyros Castañeda, M. (1996). El nuevo Derecho de Autor en el Perú, Lima: Perú Reporting.

Bell, R. T. (1991). Translation and translating; theory and practice. London and New York: Longman Group UK Limited.

Berk-Seligson, S. (1990). The Bilingual Courtroom. Chicago: The University of Chicago.

Alcaraz Varó, E. y Hughes, B. (2009). El español jurídico (2ª ed.). Barcelona: Editorial Ariel, S.A.

Bestué, C. y Orozco, M. La necesidad de la naturalidad en la reformulación en la traducción jurídica en la 'era de la automatización' de las traducciones. Recuperado de http://www.jostrans.org/issue15/art_bestue.pdf

Bielsa, R. (1987). Los Conceptos Jurídicos y su Terminología. Buenos Aires: Ediciones Palma.

Bouvier, H. G. Lenguaje y teoría del Derecho. Tensiones en una variante del realismo jurídico. Recuperado de http://www.isonomia.itam.mx/docs/isonomia35/Isono_352.pdf

Cabré, M. T. La terminología en la traducción especializada. Recuperado de http://www.upf.edu/pdi/dtf/teresa.cabre/docums/ca04tr.pdf

Cabré, M. T. ¿Lenguajes Especializados o lenguajes para propósitos específicos? Recuperado de www.google.com.pe/?gws_rd=cr\&ei=k0KyUsCfLozfkQfJ3IH4Aw\#q=\%C2\%B Flenguajes+especializados+o+lenguajes+para+propositos+especificos+maria+te resa+cabr\%C3\%A9 
Cabré, M. T. Terminología y Normalización Lingüística. Recuperado de http://www.ei.ehu.es/p05612532/eu/contenidos/informacion/euskara_inst_jardu naldiak2002/eu_jard2002/adjuntos/01.pdf

Campos Flores, E. P. y Sepúlveda Hales, B. (2013). El Realismo Jurídico Norteamericano: Escuela de Derecho. (Memoria para optar al grado de Licenciado en Ciencias Jurídicas y Sociales). Facultad de Derecho, Universidad de Chile.

Carriscondo-Esquivel. (2010). Filología frente a traducción en la elaboración de un diccionario histórico. Lexis. Revista de Lingüística y Literatura. Lima: Pontificia Universidad Católica del Perú. Lima, 5 - 32.

Cerrón-Palomino. (1997). Las primeras traducciones al quechua y al aimara: un caso de elaboración y desarrollo estilísticos. Recuperado de http://revistas.pucp.edu.pe/index.php/boletinira/article/viewFile/9742/10153

Cieza Castellano, R. (2012). El perito traductor en el contexto jurídico peruano (1 ${ }^{\mathrm{a}}$ ed.) Lima: Editorial Arkabas S.A.C.

Cisneros, L. J. (1995). Sobre la traducción. Recuperado de file:///C:/Users/Jorge/Downloads/9699-38374-1-PB.pdf

Coseriu, E. (Vol. XXI N² 2, 1997). Alcances y límites de la traducción. Lexis. Revista de Lingüística y Literatura. Lima: Pontificia Universidad Católica del Perú, 163 184.

De Loynes de Fumichon, B. (2013). Introduction au droit comparé. Journal de Droit Comparé Du Pacifique. Collection ‘Ex Professo' Volume II.

De Cruz, P. (1993). A modern approach to Comparative Law. Kluver Deventer-Boston.

Díaz Muñoz, M. Estudio del nivel de especialización del vocabulario jurídico penal en un texto de divulgación. Recuperado de www.ugr.es/ greti/puentes/puentes2/09articulo.pdf

Duro Moreno, M. (2005). Introducción al Derecho Inglés. La traducción jurídica inglésespañol en su entorno. Madrid: Edisofer S.L.

Duro Moreno, Miguel. (2000). ¿Especial o Especializada?: La traducción al español del Derecho Inglés. Recuperado de http://www.tradulex.com/Actes2000/Duro.pdf 
Gámez, R. y Cuñado, F. (2014). Introducción al Common Law [Versión PDF] Recuperado de http://traduccion jurídica.es/recursos

Gámez, R. y Cuñado F. (2015). El lenguaje de los juristas [Versión PDF]. Recuperado de http://traduccion jurídica.es/recursos

Gámez R. y Cuñado F. (2016). Trampas y Trucos de los Contratos Internacionales [Versión PDF]. Recuperado de http://traduccion jurídica.es/recursos

Garatea Grau, C. (1993). El lenguaje jurídico: un ensayo sobre su funcionamiento. (Tesis para optar el grado de Bachiller en Derecho). Lima: Pontificia Universidad Católica del Perú.

García Yebra, V. (1983). En torno a la traducción. Madrid: Gredos.

García Yebra, V. (1984). Teoría y práctica de la traducción. Madrid: Gredos.

García Yebra, V. (1985). Traducción y enriquecimiento de la lengua del traductor. Madrid.

García Belaunde, D. (1982). Conocimiento y Derecho (Apuntes para una Filosofía del Derecho). Lima: Fondo Editorial - Pontificia Universidad Católica del Perú.

Gergely, S. (1985). Microelectrónica. Barcelona: Salvat Editores S.A.

Gutiérrez G., R. La traducción de los clichés en textos jurídicos. (Tesis, Facultad de Lenguas Modernas). Universidad Ricardo Palma.

Herbert, J. Manuel de l'interpréte. ( $2^{\mathrm{a}}$ ed.). Geneve: Librairie de l'université.

Hirmer. ¿Por qué se deberían confiar las traducciones jurídicas a un traductor jurídico? Recuperado de http://www.hirmer traducciones.es/pdf/51_08_NJW_ASP_Uebersetzer.pdf

Holl, I. La Traducción Jurídica: entre el Derecho Comparado y el Análisis Textual Contrastivo. Recuperado de http://campus.usal.es/ tradop/wpcontent/uploads/2010/08/La-traducci\%C3\%B3n-jur\%C3\%ADdica-entre-elderecho-comparado-y-el-an\%C3\%A1lisis-textual-contrastivo.pdf

Icardi, A. Las cortes de Equidad en el Sistema de la Common Law. DERECHO $N^{o} 9$, Lima: Pontificia Universidad Católica del Perú. 
Lane, A. (1982). Legal and Administrative Terminology and translation problems. LANGAGE DE DROIT ET TRADUCTION - The Language of the Law and Translation. Québec, Départment de linguistique et philology de l’Université de Montréal.

Lázaro, F. y Tuson, V. (1981). El Lenguaje Jurídico y Administrativo. Curso de Lengua Española. Madrid: Ed. Anaya.

Larrauri, L. y Monteagudo, M. A. La Ambigüedad en el Lenguaje Jurídico: ¿Amplitud o distorsión semántica? Recuperado de http://www.colegiodetraductores.org/zona2.asp?IDM=00006\&IDSM=00001\&I $\mathrm{DL}=1 \& \mathrm{IDDOC}=00159$

Mayoral Asensio, R. ( $\mathrm{N}^{\circ}$ 2, Noviembre, 2002). ¿Cómo se hace la traducción jurídica? Puentes. Recuperado de http://wdb.ugr.es/ greti/revista-puentes/pub2/02articulo.pdf

Mayoral Asensio, R. La Traducción Oficial (Jurada) y Funciones. Recuperado de http://www.ugr.es/ rasensio/docs/Funciones_.pdf

Mayoral Asensio, R. ¿Cuánto derecho debe saber el traductor jurídico?. Recuperado de www.ugr.es/ rasensio/docs/Cuanto_Derecho.pdf

Mayoral Asensio, R. Las Fidelidades del Traductor Jurado: Batalla Indecisa. Recuperado de http://www.ugr.es/ rasensio/docs/Fidelidades_.pdf

Mazzarese, T. La Traducción Jurídica como Interpretación. Recuperado de file:///C:/Users/Jorge/Downloads/la-interpretacin-jurdica-como-traduccinesclarecimientos-provenientes-de-una-analoga-comn-0\%20(1).pdf

Miranda, L. (1997). La traducibilidad: ¿un mito moderno? Revista del Colegio de Traductores del Perú, 3-10.

Mould de Pease, M. (1989). Historia y traducción, presentación de una situación intra americanista. Recuperado de file://C:/Users/Jorge/Downloads/9561-37811-1PB.pdf

Mould de Pease, M., Gagnero de Trigoso, D., Morales, M. L. y otros. (1988). Actas del primer encuentro nacional de traductores. (2 vol.), Lima: Índice Editores Asociados S.A. 
Mounin, G. (1976). Linguistique et traduction. Bruselles: Dessarf et Mardaga Editeurs.

Newmark, P. (1981). Approaches to translation. Oxford: Pergamon Press.

Pigeon, L.-P. (1982). La traduction juridique -L'équivalence fonctionnelle. Langage du droit et traduction. Québec : Linguatech Collection and Conseil de la lange francaise. pp 271-281.

Pizarro, M. del C. (1994). La situación actual de la Traducción Pública Juramentada. Actas. Lima: Traductores Asociados S.R.L., 11-17.

Praeli Pérez, J. E. (2013). La Traducción Certificada: ¿una nueva forma de traducción o más de lo mismo? Recuperado de www.detrasdelacortina.com.pe/leer.php?sec $=2 \& c d=316$

Praeli Pérez, J. E. (2014). Contract: ¿contrato o un caso de "falso amigo"?. Recuperado de http://traductosphera.blogspot.com/2014/02/contract-contrato-o-un-caso-defalso.html

Quintana Paz, M. Á. (2014). Observaciones críticas sobre cierta noción dizque hermenéutica de lo que es traducir. Recuperado de http://quintanapaz.es/archivos/observaciones.pdf

Radulescu, M. (1994). Análisis del discurso aplicado a la traducción de textos periodísticos, jurídicos y literarios. Lima: Actas. Lima: Traductores Asociados S.R.L., 18-24.

Ried Undurraga, J. M. (2008). Legalizaciones y traducciones oficiales en Chile: dos anacronismos ante el comercio internacional moderno. Ius et Praxis. Talca: Universidad de Talca, 1-24.

Rubio Correa, M. (1999). Estudio de la Constitución Politica de 1993. Lima: Fondo Editorial - Pontificia Universidad Católica del Perú. 6 Vol.

Seleskovitch, D. (1978). Interpreting for International Conferences. Pen and Booth.

Seleskovitch, D. y Lederer, M. (1986). Interpréter pour traduire. Paris : Publications de la Sorbonne.

Sevillano Altuna, E. (1987). Los lenguajes del jurista. Trujillo: Departamento de Idiomas I Lingüística de la Universidad Nacional de Trujillo 
Solá, Donald F. (2001). Las lenguas mundiales: nuevos vehículos de comunicación. Lexis. Revista de Lingüística y Literatura, Pontificia Universidad Católica del Perú, 319 - 336.

Tabernig de Pucciarelli, E. (1980). ¿Qué es la traducción?: Ed. Columbia.

Vásquez Ayora, G. (1983). Introducción a la traductología. Georgetown: University Press.

Witthaus, R. (1981). Régimen Legal de la Traducción y del Traductor Público. Buenos Aires: Abeledo-Perrot.

Zierir, E. (1979). Algunos conceptos básicos sobre la ciencia de la Traducción. Trujillo: Departamento de Idiomas y Lingüística de la Universidad Nacional de Trujillo.

Zúñiga A., R. La reestructuración como técnica de traducción y su aplicación en los documentos legales. (Tesis, Facultad de Lenguas Modernas): Universidad Ricardo Palma. 
ANEXOS 


\title{
ANEXO 1: TRADUCCIONES ESPECIALES ${ }^{29}$
}

\author{
CAPÍTULO XVII
}

\section{DE LAS TRADUCCIONES ESPECIALES}

Art. 52.- En el caso de traducciones del castellano a otros idiomas o viceversa, que no puedan ser efectuadas por no existir Traductor Público Juramentado, merecerá fe pública la traducción realizada por:

1. Embajada acreditada ante el Estado peruano.

2. Universidad que cuente con Facultad de Traducción.

3. Centro de enseñanza del idioma que cuente con personal que pueda traducir.

4. Traductor especializado en el idioma requerido."

En los casos señalados en los incisos anteriores, la traducción merecerá fe pública cuando sea registrada por la Junta de Vigilancia de Traductores Públicos Juramentados.

Art. 53.- Para ser registrada una Traducción Especial, según lo previsto en el numeral anterior, requerirá:

a) la autenticación por el funcionario diplomático de la Embajada acreditada ante el Estado Peruano.

b) la autenticación por el representante legal de la universidad que cuente con facultad de traducción.

${ }^{29}$ Extracto del Decreto Supremo N ${ }^{\circ} 126-2003-R E$. 
c) la autenticación por el representante legal del centro de enseñanza del idioma que se desee traducir;

d) la autenticación por el representante legal de la entidad especializada responsable de la traducción; y

e) la legalización notarial previa de la declaración jurada que confirme la fidelidad de la misma al original, suscrita por el traductor especializado.

Art. 54.- En el caso de Traducciones Especiales efectuadas en el Perú, la declaración jurada será legalizada por notario público y certificada por la Junta de Colegio de Notarios del Perú, luego de lo cual será remitida a la Junta de Vigilancia de los Traductores Públicos Juramentados para su registro. En este estado, el funcionario que designe la junta dejará constancia en el documento que la traducción ha sido realizada en virtud de lo señalado en el artículo $48^{\circ}$ [debe decir: el artículo $52^{\circ}$ ], sin juzgar la conformidad de la traducción, para lo cual estampará un sello con la siguiente leyenda:

"Visto por la Junta de Vigilancia de los Traductores Públicos Juramentados Traducción Especial realizada en virtud del Art. $48^{\circ}$ del Reglamento de los Traductores Públicos Juramentados.”

Art. 55.- En el exterior, la declaración jurada que señale la fidelidad de la traducción al original, será legalizada por el Cónsul del Perú en la localidad o por el funcionario encargado de la Sección Consular de la Embajada del Perú, en cuya jurisdicción se realizó la traducción; luego de lo cual deberá ser autenticada por el Departamento de Legalizaciones del Ministerio de Relaciones Exteriores.

La declaración jurada legalizada, con la traducción y el documento original, serán remitidos a la Junta de Vigilancia de los Traductores Públicos Juramentados para su registro como Traducción Especial, conforme al procedimiento establecido en el artículo 50 . 
Art. 56.- La Junta de Vigilancia de los Traductores Públicos Juramentados llevará un Registro de Traducciones Especiales en el que se consignará, fecha, nombre del solicitante, nombre del traductor o entidad y denominación del documento. Llevará además del registro señalado, un archivo que contendrá una copia simple de los documentos presentados para el registro.

Art. 57.- El traductor es responsable administrativamente, civil y penalmente por los daños y perjuicios que pueda ocasionar una traducción defectuosa que no guarda fidelidad al documento. Dicha responsabilidad, alcanzará de ser el caso, al representante legal de la Universidad que cuente con la Facultad de Traducción, del centro de enseñanza del idioma que se desee traducir o de la entidad especializada.

Art. 58.- La intervención de la Junta de Vigilancia de Traductores Públicos Juramentados no generará responsabilidad administrativa, civil o penal para sus integrantes, sobre la conformidad de la Traducción Especial registrada." 


\section{ANEXO 2: EL EXPEDIENTE FUJIMORI ${ }^{30}$}

"La inexplicable demora en la traducción del cuadernillo de extradición de Alberto Fujimori, pone sobre el tapete las serias deficiencias del Poder Judicial peruano. En principio, por no haberse realizado un proceso adecuado de licitación para lograrlo.

Desde hace tres años la empresa Learning, que tiene la concesión, decide quién puede o no ser traductor del PJ. Además su propietaria, Mary Ann Monteagudo, es también miembro del comité que evalúa a los postulantes a traductores oficiales, los únicos que pueden trabajar para el PJ.

Eso no es todo. La resolución con los resultados del último proceso de evaluación de traductores que debió estar lista en enero de este año recién fue publicada el 21 de noviembre. En ella se nombra a Isabel Fukuhara como traductora oficial en japonés. Así, ella sería la única en el país que podría encargarse de la traducción del pedido de extradición de Fujimori. Si Fukuhara hubiera sido nombrada a tiempo la traducción habría estado lista antes de octubre. Pero no fue así y Learning realizó la primera traducción del expediente, la misma que fuera devuelta por deficiencias en junio. Un mes después se designó en Japón al perito Alberto Matsumoto, pero éste no llegó a suscribir el contrato (CARETAS 1748). Ahora, la traducción de los 700 folios del exhorto pasarían a manos de Fukuhara, quien, como ha trascendido, espera cobrar US\$ 70,000.

En lo que va del año el PJ ha pagado a Learning cerca de 2 millones de soles por sus servicios de traducción a otras lenguas. Vale la pena recordar que Learning fue contratada en el año 2000 por David Pezúa y José Dellepiane, quienes dirigían la institución al ritmo del fujimontesinismo."

${ }^{30}$ En: http://www.caretas.com.pe/2002/1750/secciones/marfon.phtml 


\section{ANEXO 3: CAMPAÑA CONTRA LA TRADUCCIÓN OFICIAL (I) ${ }^{31}$}

\section{OSCE INHABILITA EN UN SANTIAMÉN A PROVEEDORES POR NO TENER "TRADUCCIÓN OFICIAL"}

Imagínese, amigo lector: Usted tiene una pequeña, mediana o gran empresa que comercializa bienes o servicios TIC. En su transcurrir, ha decidido participar en convocatorias que publican las entidades del Estado Peruano, vía el Sistema Electrónico de Contrataciones del Estado (SEACE). A propósito, el gobierno de turno y el Organismo Supervisor de Contrataciones del Estado (OSCE) siempre señalan que se quiere propiciar una mayor participación de postores en las licitaciones, concursos, etc., que siempre convocan para desarrollar a las empresas, lograr mejores costos, mejorar la competitividad en el mercado, etc.

De pronto, su empresa está participando en una licitación en donde le solicitan adjuntar, entre otros, un conjunto de certificados como, por ejemplo, los certificados de los fabricantes.

Ocurre que usted verifica que los certificados de fabricantes de los productos que usted está ofertando están en idioma extranjero. Usted se preocupa, porque la ley y el reglamento de contrataciones estipulan que todos los documentos obligatorios deben estar en idioma castellano.

Sin embargo, se tranquiliza, a continuación, cuando algún amigo le dice que la forma legal de salvar es, adjuntando a los certificados, la correspondiente "traducción certificada" realizada por un traductor público juramentado. No obstante, -le dice su amigo- no será suficiente con ello, porque de ganar la licitación, usted deberá entregar la

${ }^{31}$ De: americasistemas.com.pe (Noticiero Digital $N^{\circ}$ 685) publicado el 16 de enero de 2014. 
"traducción oficial" de dichos certificados, a más tardar en siete días hábiles contados a partir del consentimiento de la buena pro, es decir, desde la fecha en que se oficializa que indiscutiblemente la empresa es la que ganó la licitación o que logró la tan ansiada buena pro.

Así, su empresa se presenta a la licitación, y encima -en el colmo de la buena suerte- resulta que es postor único. Es decir, no tiene competidores. Se desarrolla el primer y segundo acto, y le otorgan la buena pro. Alguien desde la mesa (del Comité Especial, que ha efectuado la evaluación) lo felicita y le dice que con la buena pro se acaba de dar en simultáneo el consentimiento de la buena pro. Lo felicita más, y en medio de ello le recuerda que dentro de siete días hábiles debe entregar la traducción oficial de los certificados de fabricantes. Usted lo toma con tranquilidad, en la idea que es solamente un trámite administrativo ante algún traductor.

Un escalofrío recorre su ser, cuando su amigo le precisa que obtener una traducción oficial no es realizar un mero trámite ante un notario local. Es seguir todo un "tour" -le dice- que debe recorrer desde el país de origen (del fabricante), en donde debe lograr autenticaciones, visaciones, etc., ante un notario de ese país, los consulados en ese país, etc. Después hay que traer todos los documentos al Perú, hacerlos traducir por un traductor público juramentado, llevarlos al Ministerio de Relaciones Exteriores, para al final lograr que los documentos obtenidos tengan el sello de "traducción oficial".

Atónito, usted le echa un vistazo a los originales de los certificados del fabricante, que están en idioma extranjero, y se pone al borde del infarto, cuando verifica que han sido emitidos en China. Usted se pregunta: ¿Deberé entonces, viajar a China para comenzar el dichoso "tour" y seguir todas las etapas mencionadas, para finalmente lograr la “traducción oficial”? Sí, le responde su amigo.

¡No puede ser! ¡Esto es un absurdo! ¡En siete días hábiles es imposible obtener esa traducción oficial! ¿Por qué hay que seguir todo ello simplemente porque los evaluadores solo saben español? ¿Si quieren tener la traducción, por qué simplemente no 
permiten que ella sea brindada por un traductor público juramentado y colegiado, sin tener que ir al país del fabricante? ¿Acaso el OSCE señala que los documentos que se incluyen tienen carácter de declaración jurada? Entonces, ¿dónde está la presunción de buena fe?

Esas y otras frases son algunas de las que le brotan de lo más profundo. Pero, no hay nada que hacer. La Ley y el reglamento lo dictaminan. El OSCE lo entenderá, pero igual lo sancionará.

Con todo ello, han transcurrido siete días hábiles, y usted solo pudo cumplir con una o dos etapas, de un conjunto de "n" etapas para obtener la traducción oficial.

La entidad que le dio la buena pro, se la revoca por no haber cumplido con dicho requisito para la firma del contrato respectivo. Pasan solo unas semanas y el temido Tribunal del OSCE dictamina que su empresa queda INHABILITADA por un mínimo de seis meses, para contratar con cualquier entidad del Estado Peruano.

Usted y su empresa acaban de pasar a engrosar la fila, que está siendo cada vez más larga, de proveedores que por no entregar una "traducción oficial", han quedado inhabilitados para contratar con el Estado porque de ningún modo podrían viajar a Singapur, Malasia, Hong Kong, etc. para obtener esta dichosa traducción. ¿Esto es una ficción? ¡No! Es toda una realidad, sino lo cree que se lo cuenten los profesionales o emprendedores de las firmas proveedoras que ya están inhabilitadas.

Si usted, amigo lector, tiene algún comentario en relación a todo ello escríbanos. Este es un tema sumamente grave, que por lo que nos cuentan, nadie o casi nadie ha querido poner en evidencia. Toca, entonces, a América Sistemas asumir la bandera, sin falsos chauvinismos u otros motivos. 


\section{ANEXO 4: CAMPAÑA CONTRA LA TRADUCCIÓN OFICIAL (II)}

\section{CUMPLIMOS CON NUESTRA LABOR}

(americasistemas.com.pe. Lima, Perú - 7 de mayo de 2014) En el marco de nuestra edición 700, nos complace saber que la campaña originada por América Sistemas sobre la supresión del requisito de presentación de la traducción oficial presentada por traductor público juramentado de los documentos en idioma distinto al castellano, que debía acompañar la traducción certificada para la suscripción del contrato de un postor ganador de un proceso de selección con el Estado, ha dado sus frutos.

La presentación de este requisito estaba demás, pero se argumentó -en su momento- que era para "brindar mayor certeza a la Entidad respecto de la información contenida en estos". Además, el plazo para presentar dichas traducciones oficiales era muy corto.

El Decreto Supremo N 080-2014-EF que modifica el Reglamento del Decreto Legislativo N 1017 que aprobó la Ley de Contrataciones del Estado, aprobado mediante Decreto Supremo $\mathrm{N}^{\circ}$ 184-2008-EF, entró en vigencia el pasado martes 22 de abril, considerando la citada supresión.

Sin embargo, y aunque el susodicho Decreto Supremo no es retroactivo, es necesario conocer cuál será el destino de los proveedores que obtuvieron la buena pro en los procesos de selección y fueron inhabilitados de las contrataciones con el Estado debido a este antojadizo requisito. Asimismo, desconocemos cómo quedan los proveedores que invirtieron sumas de dinero, en los últimos meses, para financiar las 
traducciones oficiales que eran solicitadas. En todo caso, el Organismo Supervisor de las Contrataciones del Estado (OSCE) tiene la última palabra.

Por nuestra parte, nos sentimos satisfechos de haber cumplido con informar sobre este hecho que afectaba claramente a diversas empresas del sector TIC y de otras industrias, así como de contribuir con la mejora de la gestión pública de nuestro país.

En esta línea, hemos recibido comunicaciones vía telefónica y por email en donde nuestros lectores expresan sus felicitaciones por nuestro compromiso en promover justos procedimientos en los procesos de contrataciones con el Estado.

Asimismo, representantes de instituciones nos han expresado su complacencia por la supresión del requisito de las traducciones oficiales. Sin embargo, nos extraña que recién se hayan manifestado. Cuando el tema parecía que se iba a consolidar, ¿dónde estuvieron?

Sea como fuere consideramos, desde nuestra tribuna periodística, que es posible contribuir al desarrollo del país de diversas maneras. En nuestro caso, a través de información fidedigna y de valor, cumplimos con servir a nuestros lectores y al mercado TIC nacional. Por eso, las congratulaciones recibidas las compartimos con Uds. 


\section{ANEXO 5: PROYECTO DE LEY DE CREACIÓN DEL REGISTRO DEL TRADUCTOR E INTÉRPRETE ESPECIALIZADO}

\section{EXPOSICIÓN DE MOTIVOS:}

Desde inicios de los años 90 el Perú se ha reinsertado con la comunidad internacional. Como consecuencia de esta medida, el flujo de documentos de todo tipo desde o hacia el extranjero se ha incrementado de manera notable. Igualmente ha sucedido con el desplazamiento de las personas hacía o fuera del Perú.

Además, muchos de estos documentos se encuentran en otros idiomas por lo que se precisa su traducción al idioma oficial del Perú. Igualmente ocurre con los documentos que son enviados a otros países. En el caso de personas que hablan otros idiomas se ha tenido que recurrir a intérpretes para una debida comunicación contando en muchos casos con profesionales extranjeros que acompañaban a científicos, investigadores, empresarios, conferencistas, pastores religiosos, artistas, deportistas, políticos entre otros ante la ausencia de profesionales nacionales competentes.

Sin embargo, a pesar de ser la traducción (en sentido amplio) una actividad que se pierde en el tiempo, nuestro país no tiene mayor tradición en esta disciplina a tal extremo que no existen estudios, publicaciones, centros de investigación o autores reconocidos que hayan aportado su conocimiento de manera integral para optimizar los servicios descritos.

En dicho contexto los traductores del Ministerio de Relaciones Exteriores en un número de 68 a la fecha se han visto rebasados en sus expectativas al contar con profesionales en solo 09 idiomas de los potenciales 7,102 que existen. Solo la Unión Europea cuenta con 24 idiomas oficiales, lo que indica la pobreza de la oferta nacional. Igualmente esta gran demanda ha llevado a la creación de entidades privadas como la ATPP (Asociación Peruana de Traductores Profesionales del Perú), la APETEC (Asociación Peruana de Traductores Técnicos-científicos), JULIA (Juristas-Lingüistas 
Asociados) entre otras. En el sector público, se creó el CTP (Colegio de Traductores del Perú) recién en el año 1996 con colegiatura voluntaria. Asimismo, tanto universidades como institutos han empezado a ofrecer esta carrera. Las universidades que ofrecen esta carrera son: la Universidad Femenina del Sagrado Corazón (UNIFE), la Universidad Particular Ricardo Palma, la Universidad Peruana de Ciencias Aplicadas del Perú (UPC) y la Universidad César Vallejo. En el nivel técnico, los Institutos que la ofrecen en la actualidad son básicamente EUROIDIOMAS y CYBERTEC. También existen otras instituciones que de manera complementaria la ofrecen como es el caso de la Academia de Secretariado Margarita Cabrera.

Sin embargo, la legislación que regula esta actividad ha sido desordenada y confusa exigiendo a los usuarios (públicos y privados) requisitos de difícil cumplimiento para el tratamiento del trámite documentario. En la gran mayoría de los casos la ley ha dispuesto que sean los TPJ del referido Ministerio de Relaciones Exteriores los encargados de esta labor; sin embargo las consecuencias de dichas medidas han generado incluso más confusión que solución, tanto en la prestación de los servicios como en la expectativa de los usuarios, entre otras cosas por lo oneroso del servicio y por la falta de especialización de los actuales traductores. Esto ha dado como resultado que algunas entidades tengan que modificar su normativa para reducir o evitar conflictos producto de dicha legislación.

Un ejemplo es la legislación del Traductor Público Juramentado (TPJ) del Ministerio de Relaciones Exteriores, Decreto ley $N^{\circ} 18093$, que disponía que el mercado de los TPJ solo debían estar compuesto por particulares pero la demanda se ha incrementado en tal magnitud que también han sido las entidades públicas, los Poderes del Estado para no solo conocer el contenido del mensaje sino en la tramitación de documentos necesarios como en el comercio internacional, cooperación ente Estados, trámites en procesos civiles, penales y otros a nivel internacional como para extranjeros residentes en el país que no conocen el idioma.

Esto con otras consideraciones hace que sea necesaria una nueva ley que dé solución a todos estos problemas y al mismo tiempo permita elevar el nivel de calidad del servicio ofrecido así como reducir sus precios producto de la competencia. 


\section{ANÁLISIS COSTO BENEFICIO:}

Los costos que implicarían una nueva ley serían principalmente:

a) Los costos asociados a la implementación de un Registro el cual podría estar depositado en los archivos de un determinado Ministerio como el de Justicia o Cultura de preferencia para su fácil ubicación y referencia.

b) El tiempo invertido para la realización de la respectiva convocatoria de todos los traductores en funciones y la revisión de sus respectivos CV para dar el visto bueno para su inscripción en el Registro.

c) Disponer de un ente contralor conocedor de esta disciplina de reconocida solvencia profesional para la aplicación de las posibles sanciones administrativas que puedan cometer los inscritos en el Registro así como absolver las consultas que se le pudieran hacer.

Sin embargo, ya existe un ente (Junta de Vigilancia) en el Ministerio de Relaciones Exteriores que realiza las labores descritas aunque de manera deficiente, según pensamos. Por su parte, los beneficios serán:

a) Al ser contenida en una sola ley, se uniformiza la legislación a todo nivel el tratamiento que se le debe dar a este servicio y se evita la producción de nuevas normas inconexas y el costo que ello implicaría como ha estado sucediendo.

b) Hacer que dicho servicio sea más idóneo y más justo al promover la competencia entre los traductores inscritos y los no inscritos quienes eventualmente podrían solicitar su incorporación a dicho Registro.

c) Promover la especialización entre los traductores y su constante capacitación y actualización dentro de su respectiva especialidad.

d) Reducción en los costos de transacción para que un profesional de la especialidad requerida sea fácilmente ubicado con las características que el usuario desea. 


\section{ANÁLISIS DE IMPACTO DE LA NORMA EN LA LEGISLACIÓN NACIONAL:}

El impacto en la normativa nacional puede resumirse de la siguiente manera:

a) La primera consecuencia es que se logrará que el status del traductor e intérprete sea único, es decir desparecerán las diferencias legislativas entre uno y otro y todos estarán en la misma condición de poner competir y ofrecer sus servicios ante cualquier usuario sea persona natural o jurídica, de naturaleza privada o pública sin distinción que lo perjudique.

b) Se creará una clara distinción académica de las competencias entre los traductores, lo que no había antes.

c) No se afectará para nada el ejercicio de los traductores registrados en el CTP debido a que su membresía es voluntaria. Es decir, su actividad seguirá tan igual a como lo viene haciendo actualmente.

d) Permitirá eventualmente a los traductores experimentados poderse colegiar en el Colegio de Traductores del Perú, lo que permitirá elevar el nivel del servicio.

e) Al lograr que voluntariamente se incorporen al CTP, se acabarán los conflictos que existen en la actualidad.

f) El Ministerio de Relaciones Exteriores se verá librado de regular esta actividad para lo cual no cuenta con un personal capacitado a la fecha y tampoco pueda especular con realizar convocatorias o limitándolas de manera arbitraria sin dar razones atendibles o por intereses desconocidos.

\section{TÍTULO I}

DISPOSICIONES GENERALES 


\section{CAPÍTULO I}

\section{GENERALIDADES}

\section{Artículo 1.- Objeto de la Ley}

El objeto de la presente Ley es crear el Registro del Traductor e Intérprete Especializado del Ministerio de Cultura. El Traductor e Intérprete Especializado Registrado es un profesional que se encarga de la traducción de textos especializados tanto de manera directa como inversa. Ambas funciones las puede realizar la misma persona.

\section{Artículo 2.- Registro de Traductores e Intérpretes Especializados}

El Ministerio de Cultura llevará cuatro registros de Traductores e Intérpretes Especializados:

I. Registro de Traductores e Intérpretes Literarios: Registro que contendrá información de consulta de las personas cuya especialidad es la traducción y/o interpretación de textos literarios.

II. Registro de Traductores e Intérpretes Jurídicos: Registro que contendrá información de consulta de las personas cuya especialidad es la traducción e interpretación de textos jurídicos y de temas anexos al Derecho.

III. Registro de Traductores e Intérpretes Técnico-científicos: Registro que contendrá información de consulta de las personas cuya especialidad es la traducción de textos científicos o técnicos y de temas anexos a la ciencia o tecnología.

IV. Registro complementario de Traductores e Intérpretes Especializados: Registro que contendrá información de consulta de las personas cuya especialidad no se encuentra regulada en los registros anteriores.

\section{Artículo 2.- Definiciones}


Para efectos de esta ley, se entiende por:

I. Traducción: Traslado, en una lengua, de lo escrito o expresado en otra.

II. Traductor e Intérprete Especializado con Registro: Persona natural reconocida por el Estado de acuerdo con las disposiciones de la presente Ley, encargado de realizar traducciones e interpretaciones especializadas de manera directa o inversa de temas de su especialidad. El Traductor e Intérprete Especializado Registrado también se encarga de analizar, interpretar y comentar los textos que traduce.

III. Textos Especializados: Documentos que contienen una terminología especializada perteneciente a una rama del conocimiento.

IV. Interpretación: Transposición oral de los términos especializados que se hace del español a otra lengua o viceversa.

V. Intérprete: Profesional con el conocimiento suficiente del idioma español, de una rama del conocimiento y de una o más lenguas adicionales para trasladar, oralmente y de manera idónea, los términos de la lengua fuente a la lengua meta.

VI. Lengua fuente: Lengua del documento o de la expresión original a partir de la cual se realiza la traducción o interpretación.

VII. Lengua meta: Lengua hacia la cual se traduce o interpreta un documento.

\section{CAPÍTULO II}

\section{ACREDITACIÓN DEL TRADUCTOR EXPERTO REGISTRADO}

\section{Artículo 3.- Acreditación del Traductor e Intérprete Especializado}

El Traductor e Intérprete Especializado Registrado ejerce su función con acreditación estatal desde el momento de su inscripción en el Ministerio de Cultura. La convocatoria para inscribirse en el Registro Nacional de Traductores e Intérpretes Especializados del Ministerio de Cultura está abierta a todo tipo de personas naturales, tengan o no tengan título profesional o técnico en estas disciplinas. 
En el caso que tuviesen títulos profesionales o técnicos en estas disciplinas, así como otro tipo de estudios vinculados a estas materias no constituyen una exigencia para postular y ser incluidos en el Registro.

\section{Artículo 4.- Requisitos de inscripción}

El registro como Traductor e Intérprete Especializado se realizará en el Ministerio de Cultura y exige el cumplimiento de los siguientes requisitos.

1. Tener la nacionalidad peruana o contar con una residencia mínima de cinco años en el país.

2. Ser mayor de edad.

3. Contar con título profesional o técnico en estudios distintos a la traducción o interpretación.

4. Documentación que demuestre haber realizado la labor de traductor y/o intérprete en temas de su especialidad durante 05 años.

5. Los que tienen título profesional o técnico traducción o interpretación, solo necesitan acreditar una experiencia de 03 años.

6. Tener conocimientos actualizados en los idiomas que desea registrarse.

7. Declaración jurada de encontrarse en pleno goce de derechos civiles del solicitante.

8. Copia certificada del documento nacional de identidad del solicitante.

9. Declaración jurada de domicilio del solicitante.

10. Constancia de no registrar antecedentes penales por sentencia condenatoria.

11. Los demás que establezca la presente Ley y su Reglamento.

\section{Artículo 5.- Efectos jurídicos de la inscripción}

El registro constituye el reconocimiento estatal de que el Traductor e Intérprete Especializado es idóneo para efectuar la labor de traductor y/o intérprete de textos especializados en su respectiva especialidad. 


\section{Artículo 6.- Deberes del Traductor Especializado con Registro}

Son deberes del Traductor e Intérprete Especializado con Registro:

1.- Realizar la labor de traductor o intérprete de manera idónea en la especialidad e idiomas en la que se encuentra registrado.

2.- Desempeñar la labor en la que se encuentra registrado con la diligencia propia de un profesional competente respetando los plazos pactados para ello.

3.- Mantenerse actualizado en temas de su especialidad y en los idiomas en los que se encuentra registrado.

4.- Prestar su apoyo como peritos ante los Poderes del Estado y en sus distintas entidades de manera eficiente.

5.- Llevar un Registro ordenado de los trabajos que realice en su calidad de Traductor e Intérprete Especializado con Registro.

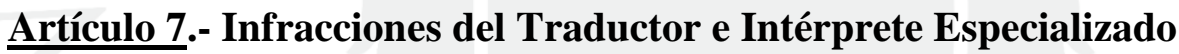

Las infracciones del Traductor Experto susceptibles de ser sancionadas, son las siguientes:

1.- Desempeñar la labor de Traductor Especializado con Registro en la especialidad e idiomas en las que no se encuentra registrado.

2.- Alterar de manera deliberada la versión de los documentos que traduce o interpreta.

3.- No guardar la confidencialidad que se le confía de los documentos que por su labor debe traducir o interpretar.

4.- Usar medios vedados para conseguir clientes o favores en el ejercicio de su labor.

5.- No permitir que la entidad correspondiente del Ministerio de Cultura fiscalice la labor del Traductor e Intérprete Especializado con Registro.

\section{CAPÍTULO III}




\section{DE LA INSCRIPCIÓN EN EL MINISTERIO DE CULTURA}

\section{Artículo 8.- Del Registro de Traductores Expertos}

El Ministerio de Cultura organizará los registros mencionados en el artículo 2 de la presente Ley donde se inscriben los Traductores e Intérpretes Especializados que hayan cumplido con los requisitos establecidos en la presente Ley.

El funcionamiento del Traductor e Intérprete Especializado con Registro se regirá por el reglamento de la presente Ley.

\section{Artículo 9.- De las funciones del Ministerio de Cultura}

El Ministerio de Cultura cumple las siguientes funciones en relación al ejercicio del Traductor Experto con Registro:

a) Organizar y administrar los Registros del Traductor e Intérprete Especializado del Ministerio de Cultura.

b) Expedir la constancia de inscripción del Traductor e Intérprete Especializado que se haya inscrito en el registro correspondiente

c) Expedir la renovación de la inscripción cada 5 años previa actualización de los datos del interesado

d) Expedir constancias y certificaciones de los actos que se hagan en los registros del Traductor e Intérprete Especializado.

CAPITULO IV

FACULTAD SANCIONADORA DEL MINISTERIO DE CULTURA

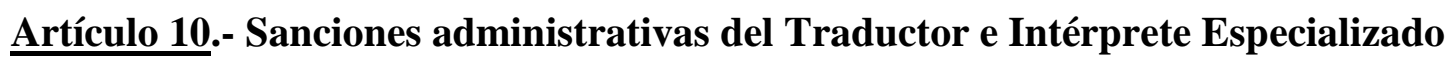


En ejercicio de su facultada sancionadora, el Ministerio de Cultura puede aplicar al Traductor Especializado con Registro las sanciones administrativas enunciadas en el artículo 7 de la presente Ley.

Las sanciones administrativas según su gravedad son las siguientes:

1.- Amonestación escrita.

2.- Multa económica de una UIT vigente al momento de la infracción.

3.- Cancelación temporal de un año del Registro del infractor.

4.- Cancelación definitiva del Registro del infractor.

\section{$\underline{\text { Artículo 11.- Fundamentos de las sanciones administrativas }}$}

La sanción que imponga el Ministerio de Cultura deberá tener en consideración los siguientes aspectos:

1.- Los daños causados por el Traductor e Intérprete Especializado.

2.- La gravedad de la infracción cometida.

3.- La intencionalidad del infractor.

4.- La reincidencia del infractor.

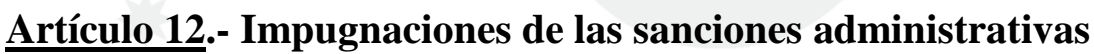

Las sanciones aplicadas pueden ser impugnadas de acuerdo a los recursos previstos en la Ley $\mathrm{N}^{\circ}$ 27444, Ley del Procedimiento Administrativo General, dentro de los plazos correspondientes.

\section{DISPOSICIONES COMPLEMENTARIAS}

PRIMERA.- La obligatoriedad del ejercicio del Traductor Especializado con Registro entrará en vigor a los 02 años de publicada la presente Ley. En consecuencia, una vez en 
vigor la presente Ley solo los Traductores e Intérpretes Especializados con Registro en el Ministerio de Cultura podrán ser designados como tales.

SEGUNDA.- El Ministerio de Cultura podrá celebrar convenios con las Universidades Públicas y Privadas así como como con Instituciones Especializadas a fin de realizar programas de capacitación y actualización de los Traductores e Intérpretes Especializados con Registro.

\section{DISPOSICIÓN FINAL}

ÚNICA.- La presente Ley entra en vigencia en el plazo de sesenta (60) días, contados a partir de la fecha de su publicación. 